\title{
Cinco piezas inéditas en loor del nacimiento de Cristo de Francisco Galeas (1567-1614). Estudio y edición
}

\section{Five Unpublished Pieces in Praise of the Birth of Christ by Francisco Galeas (1567-1614). Study and Editing}

\author{
Mercedes de los Reyes Peña \\ Universidad de Sevilla \\ ESPAÑA \\ mdelosreyesp@telefonica.net \\ Con la colaboración de \\ José Antonio Raynaud \\ Filólogo y Director de Escena \\ ESPAÑA \\ jraynaud@hotmail.com
}

[Hipogrifo, (issn: 2328-1308), 9.1, 2021, pp. 1187-1266]

Recibido: 21-09-2020 / Aceptado: 19-11-2020

DOI: http://dx.doi.org/10.13035/H.2021.09.01.67

Resumen. Estudio y edición de cinco piezas inéditas del escritor cartujo Francisco Galeas (Sevilla, 1567-1614), radicadas en la Biblioteca de la Hispanic Society of America (New York) [Sig. MS. HC380/611], compuestas con finalidad didácticomoralizadora con motivo de la celebración del nacimiento de Cristo. En ellas se manifiesta un no desdeñable conocimiento de las técnicas escénicas por el autor. Tras situarlas en su contexto, se proyectan sobre el marco del corpus teatral castellano del siglo XVI y primeros años del XVII.

Palabras clave. Francisco Galeas; Sevilla; producción inédita; nacimiento de Cristo; alegoría; teatralidad; estudio y edición. 
Abstract. Study and editing of five unpublished pieces by the Carthusian writer Francisco Galeas (Seville, 1567-1614), located in the Library of the Hispanic Society of America (New York) [Sig. MS. HC380/611] and composed with a didactic-moralizing purpose on the occasion of the celebration of the birth of Christ. In them, a not insignificant knowledge of the scenic techniques of the author is displayed. After putting them into context, they are projected onto the frame of the Spanish theatrical corpus of the XVI century and the first years of the XVII century.

Keywords. Francisco Galeas; Seville; Unpublished production; Birth of Christ; Allegory; Theatricality; Study and editing.

Francisco Galeas o Francisco Sánchez Galeas (Sevilla, 1567-1614) fue un monje perteneciente al monasterio cartujo de Santa María de las Cuevas, situado extramuros de la ciudad hispalense, a orillas del Guadalquivir, de cuya biografía y producción dramática me ocupé hace tres años en esta misma revista?. Si entonces presenté la obra teatral en su conjunto, publicando como muestra solo una pieza de ella, La historia de cuando Abraham echó de casa a Ismael y Agar, su madre (224 versos), y anunciando la edición de las restantes, en esta ocasión, como indica el título del trabajo, editaré cinco, unidas por el mismo asunto -loor del nacimiento de Cristo- y con diversos argumentos y modalidades dramáticas, las cuales, igual que la ya publicada, tienen en común su carácter inédito.

Como ya advertía en el artículo citado, no estamos ante una producción extensa, caracterizada por su excelencia, ni ante la obra de un dramaturgo profesional afamado, sino de un amateur en estas lides, pero que, por su época de creación (último tercio del Quinientos y dos primeras décadas del Seiscientos) y por sus particulares características, merece ver la luz. Conviene recordar que son estos unos años de capital importancia en la historia de nuestro teatro, debido a la profesionalización que se está gestando a pasos agigantados en la práctica escénica y a los intentos de los creadores por encontrar nuevas vías de salida a la escritura dramática, con interesantes experiencias en este sentido. De aquí, la conveniencia de ir exhumando poco a poco todos los testimonios de ese período, con bastantes textos perdidos, a los cuales, hasta los últimos tiempos de nuestra historia teatral, salvando destacadas excepciones, no se les había prestado la atención necesaria para que fuera posible la reconstrucción de una etapa crucial en la que se están afirmando las bases de las que surgirá la «Comedia nueva».

\footnotetext{
1. Reyes Peña, 2017, artículo que sirve de base a este, al que remitiré y utilizaré con frecuencia. Su objetivo fue la reconstrucción de la biografía de Galeas y la presentación de su obra dramática, situándola en su contexto y editando una de sus piezas. Agradezco vivamente a José Antonio Raynaud la exhaustiva lectura de las páginas que siguen, así como sus rigurosas correcciones, acertadas observaciones e interesantes reflexiones y adiciones respecto a la teatralidad de las piezas y su posible puesta en escena. Todo ello ha supuesto para mí un enorme estímulo en la defensa de la conjunción de la Filología y de la Práctica escénica profesional en la investigación del teatro áureo.
} 
Para situar al autor en su verdadera dimensión, antes de entrar en la consideración de su obra dramática, es preciso recordar que, tuviera o no tuviera estudios de Grado o de Doctorado -cuestión tratada en nuestro artículo de 2017-, su formación como cartujo profeso, los encargos que le hicieron sus propios compañeros de religión, los cargos que desempeñó en la Orden, sus escritos, su epitafio, la fama que como poeta y pintor alcanzó en los círculos cultos artísticos y literarios de la Sevilla de la época, y los juicios emitidos por el cartujo José María Rincón, en el Protocolo del Monasterio de Nuestra Señora de Santa María de las Cuevas [...], lo evocan como un hombre de refinada cultura y un excelente iluminador. Sus excelencias en el arte de la escritura y la pintura (en la faceta de miniaturista) fueron reconocidas, además de por su propio hermano, el licenciado Alonso Sánchez Gordillo, y por los miembros de su orden monástica, por la culta Sevilla coetánea y de siglos posteriores².

El estudioso que recoge con mayor precisión la labor de escritura de Galeas, la faceta que aquí nos interesa, es Ildefonso M. Gómez (1970), en la siguiente enumeración:

- Vida del glorioso San José, en versos castellanos. No se imprimió.

- Tratado de jeroglíficos, en prosa y verso, e ilustrados por el autor.

- Libro del Mandato, iluminado y miniado por su mano. Quedó destruido en la inundación que sufrió el monasterio en 1784.

- Libro Becerro o Protocolo, refundido y nuevamente redactado por el P. Rincón. En la cartuja Aula Dei, existe una copia parcial del mismo.

- Relación del traslado de los restos del arzobispo de Sevilla, don Gonzalo de Mena, desde la Santa Iglesia Metropolitana hasta la cartuja de las Cuevas. «Existe copia de esta obra -leemos en Ildefonso M. Gómez- en el libro de Acaecimientos dignos de memoria, en el que se reunieron copias de varios documentos, cuyos originales posee el señor Marqués de San José de la Serra».

-Otras composiciones poéticas ${ }^{3}$.

De ellas, son estas «composiciones poéticas», citadas en último término y de forma tan vaga, las que focalizarán nuestra atención, limitándonos a la producción dramática, radicada en la Biblioteca de la Hispanic Society of America (New York), MS. HC380/611, inédita hasta ahora, con la única salvedad de La historia de cuando Abraham echó de casa a Ismael y Agar, su madre, arriba aludida. 
Catalogadas por J. M. Regueiro y A. G. Reichenberger (MS. HC380/611)4 he aquí la relación de las citadas piezas:

-Representaçion breue para el dia del / Sanctissimo Sacramento [...] / (fols. 20r-21r).

-Yntroito para representaciõ a la ue- / nida del III. mo arçobispo de Seuja [...] / (fols. 94r-95r).

- Para la festiuidad del nascimi.to de / Nuestro Saluador / y pazes fechas en la discordia entre for- / taleza y flaqueza / (fols. 95v-103v).

- La historia de quando Abrahã / echo de casa a ysmael, y / Agar Su madre (fols. 105r-109v).

-Comedia yntitulada Triumpho / de pobreza contra / Riqueza (fols. 110r-132r).

-Representaçion del nasçimiento / de lesuchristo Saluador nuestro / (fols. 135r-165r), precedida por un Introito para la comedia [...] / (fols. 132v-134v).

-Dialogo de dos pastores / el uno llamado / Siluano, y el / otro alegria (fols. 173r-177v) 5 .

-A ellas, estimaría conveniente añadir el Colloquio pastoril para el sanctísimo nascimiento (fol. 195r) por su tipología teatral.

En el lomo del manuscrito que las contiene, descrito por los citados investigadores a los que remitimos, se lee: «P. Galeas. / Poesias es- / pirituales. / M.S. / Siglo 16». En la hoja de guarda hay dos notas, escritas por manos y tintas diferentes. Fechadas en el siglo XIX, descubren a dos de los poseedores del ms. en dos momentos puntuales de su historia: 1838 y 1895. La primera adjudica la autoría del manuscrito al P. Galeas, radicado entonces en la biblioteca de Juan Colón y remitiendo, a su vez, a otra obra suya, los Jeroglíficos morales; y la segunda lo muestra en posesión de D. Manuel de Lara y Alcalá, dedicándoselo a D. Antonio Cánovas del Castillo:

1) «Poesías espirituales del / P. D. Franco Galeas monje / de la Cartuja de SeviIla. / Véase la obra de este mis- / mo autor que se intitula: Hiero- / glificos morales que M.S. ecsiste entre / mis libros. Sevilla, 10 de Junio 1838 / J.n Colón» [Firma y rúbrica autógrafas]. 2) «Al Excmo. Sr. D. Antonio Cánovas del Castillo / como cariñosa prueba de respetuosa ad- / miración. / Manl de Lara / y Alcalá [Firma y rúbrica autógrafas] / Marzo 1895»6.

4. Regueiro y Reichenberger, 1984, vol. I, pp. 221-238.

5. Regueiro y Reichenberger, 1984, vol. I, pp. 224-225. En pp. 226-238, ofrecen la catalogación detallada de cada una, que aquí omito. Reproduzco los títulos por el manuscrito.

6. Regueiro y Reichenberger, 1984, vol. I, p. 223. a la que pertenecen la cita anterior y esta segunda, que he comprobado y en la cual los paréntesis entre corchetes son de mi responsabilidad. 
Aunque la descripción de Regueiro y Reichenberger es correcta y muy minuciosa, añadiremos aquí algunos otros detalles, importantes para nuestro estudio? ${ }^{7}$. El manuscrito está falto de una primera hoja, que parece arrancada, y posee un folio pegado y escrito a máquina, que contiene la descripción (en alemán) hecha por el librero Karl Hiersemann, como me informa el Dr. O'Neill, que me la remite digitalizada. En ella, se le adjudica a nuestro autor: «Galeas, Fr. o. Cart., poesías espirituales y representaciones sacras dramáticas del P. Fr. Francisco Galeas, monje de la Cartuja de Sevilla, en el siglo XVI $I^{\circ}$. Manuscrito inédito, en papel de fines del siglo XVII'. En fol. mayor. Perg. ant. 200 hojas num.»; y en una nota que sigue en lengua alemana facilita, entre otros, este interesante dato suministrado por Pascual Madoz en su Diccionario (t. XIV, p. 367), cuando, a propósito de la descripción de la rica Biblioteca de D. José María de Álava, Catedrático de Derecho Romano de la Universidad de Sevilla, alude a dos manuscritos de Galeas radicados en ella, siendo el segundo «Otro tomo en folio mayor de hermosisima letra, en el cual estan recogidas todas las poesias de Galeas, sobre asuntos sagrados, muy probablemente idéntico al presente», como se lee en la nota ${ }^{8}$. Por su valor, he aquí la cita de Madoz, transcrita desde su original:

Hieroglificos del P. Francisco Galeas, cartujano de las Cuevas, que murió a principios del siglo XVII. [...] Su grande erudición y literatura la demuestra en esta obra escrita de su mano y autorizada con su firma, a la cual acompañan multitud de empresas dibujadas e iluminadas por él mismo. Otro tomo en folio mayor de hermosísima letra, en el cual están recogidas todas las poesías de Galeas, sobre asuntos sagrados ${ }^{9}$.

7. Deseo expresar públicamente al Dr. D. John O'Neill, Jefe de Departamento de Manuscritos y Raros de la Hispanic Society of America y a esta institución, mi más sincero agradecimiento por el envío del microfilm del manuscrito y el permiso de publicación, así como las informaciones sobre el mismo y la remisión digitalizada de sus hojas de guarda delantera y trasera, que con toda amabilidad me ha enviado con motivo de este artículo. Agradezco igualmente a la Dra. D. ${ }^{a}$ María del Valle Ojeda Calvo (Universidad de Venecia) la descripción realizada del ms. durante su investigación en la Biblioteca de la citada institución (2016), describiéndome sus características y contenido, y comprobándome algunas lecciones de difícil lectura en la reproducción microfilmada que he manejado.

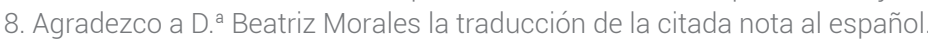

9. Madoz, Diccionario..., t. XIV, 1849, p. 367, col. b. Respecto a D. José María de Álava y Urbina (1815-1872), bibliófilo y erudito y su rica biblioteca, conviene recordar que fundó la Sociedad de Bibliófilos Andaluces, junto a Pascual de Gayangos, José María Asensio Toledo y Francisco Palomo Rubio. Su nombre aparecía con frecuencia en publicaciones literarias y artísticas debido a la valiosa colección de manuscritos y códices que conservaba en su biblioteca. Pedro Montoto y Vigil (en su Guía general de SeviIla, Sevilla, Imp. Carlos Santigosa, s. a., p. 134), afirmaba que su biblioteca era «sin duda la que después de la Colombina posee mayor número de ediciones raras y monumentos curiosos de literatura española». Y José Bisso, en 1869, la colocaba a la cabeza de las «mejores bibliotecas que hay en Sevilla», pues, «aunque no consta más que de 3.000 volúmenes, son tan ricos y escogidos, que la hacen una de las mejores de España. La colección de manuscritos es tan interesante como la de los impresos, y entre ellos se encuentra el de las poesías de Gutiérrez de Cetina, muchas aun inéditas; el del Padre Fray Hernando de Talavera, confesor de la Reina Católica; el del Padre Galeas, no tan notable; los autógrafos de Argote de Molina y otros de que disfrutó el célebre analista Zúñiga» (Crónica de la provincia de Sevilla, p. 50). Montoto y Vigil (en el libro arriba citado) no menciona ningún título o autor concreto. Sí menciona que la «librería está dividida en tres partes principales, que son: legislación, historia y literatura española. Se halla situada en la casa que habita su autor, calle de las Sierpes, núm. 34 y 35» (cita en la página arriba mencionada). 
Precisamente, de este «otro tomo en folio mayor de hermosísima letra» que Madoz tuvo la oportunidad de ver en la citada Biblioteca, hoy perdido igual que los Jeroglíficos ${ }^{10}$, debe ser copia -suponemos- de cuidada ejecución el manuscrito Galeas (como lo denominaremos en adelante) que manejamos: de tamaño folio, con 200 hojas numeradas, cuya numeración empieza en el número 1, de tinta diferente. Los cuatro primeros folios tienen, además, otra numeración (Ai-Aiiii). Las hojas de guarda son de otro papel diferente al del resto del manuscrito. Su cuidada factura es así descrita por Regueiro y Reichenberger (figs. 1, 2 y 3):

The scribe used caligraphic script imitating printed italics letters for the text. For titles, the names of characters, stage directions and others occasional remarks, he imitate printed roman type. Each page of the text is frame within double border on four sides. On the top of every page, enclosed within a separate double border from the one that encloses the text, there are the initials «S[ub] C[orrectione] S[anctae] E[cclesiae] C[atholicae] R[omane]». Occasional ornamental designs (i.e., paragraph symbol $\mathbf{9})$ that fall outside the frame are not indicate in the transcripcion ${ }^{11}$.

10. Conociendo que ambos manuscritos, en particular ese de «hermosísima letra» que recogía «todas las poesías de Galeas sobre asuntos sagrados» que es el que aquí nos interesa, se hallaban en la biblioteca de D. José María de Álava, he intentado seguir el rastro de sus fondos en un deseo de encontrarlos o de recopilar alguna noticia sobre ellos, pero todo ha sido en vano. Debido a que la mayor parte de sus fondos fueron donados por el erudito bibliófilo a la Biblioteca del Seminario Diocesano de Álava, me puse en contacto con su bibliotecaria, D. ${ }^{a}$ Amaia Gallego, en busca de la posible existencia de algún inventario o documentación relativa a dicha donación. Después de su búsqueda, me informó, con una amabilidad extraordinaria que le agradezco sinceramente, que no había encontrado nada, remitiéndome a una nota de D. Ángel Ibisate Lozares, anterior bibliotecario y expertísimo conocedor de ella, hoy lamentablemente fallecido, que respondía a mi consulta. Sobre los fondos de la Biblioteca Diocesana, escribía D. Ángel Ibisate, en 1997, que «esta recibió -como decía D. José Zunzunegui en el prólogo al Catálogo impreso [Catálogo de la biblioteca del Seminario de Vitoria, Vitoria, Seminario, 1952] - "un nuevo e importantísimo impulso con la donación del ilustre alavés D. José María Aguirre [sic por Álava] [...] La gran mayoría de los manuscritos, incunables, ediciones de los siglos XVI y XVII y obras de Derecho proceden de aquel rico fondo" (p. VI). Desgraciadamente -continúa escribiendo D. Ángel Ibisate-, al incorporarla a la Biblioteca, se dispersó por las distintas secciones temáticas. Su extraordinaria riqueza está clamando por la reunificación y catalogación como tal. No tengo indicios de la existencia de un catálogo o inventario de la misma, ni he logrado siquiera hallar noticia sobre la forma concreta ni el momento de su llegada a nuestra Biblioteca» (Ibisate Lozares, 1997, pp. 316-317, nota 8).

11. Regueiro y Reichenberger, 1984, vol. I, p. 223. 


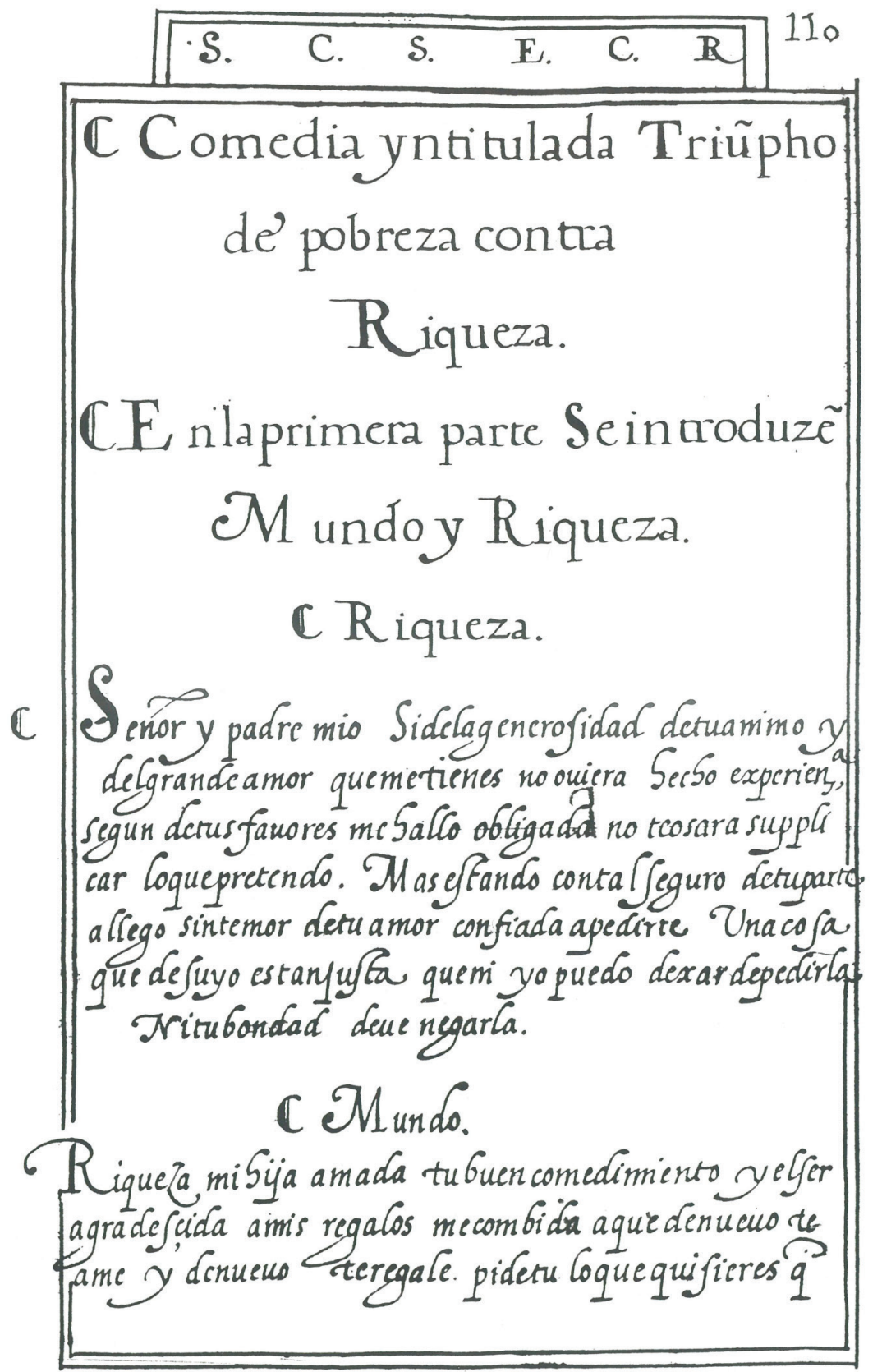

Fig. 1. Francisco Galeas, Comedia intitulada Triunfo de Pobreza contra Riqueza (New York, The Hispanic Society of America, MS. HC380/611

[Poesías espirituales y representaciones sacras dramáticas], fol. 110r) 


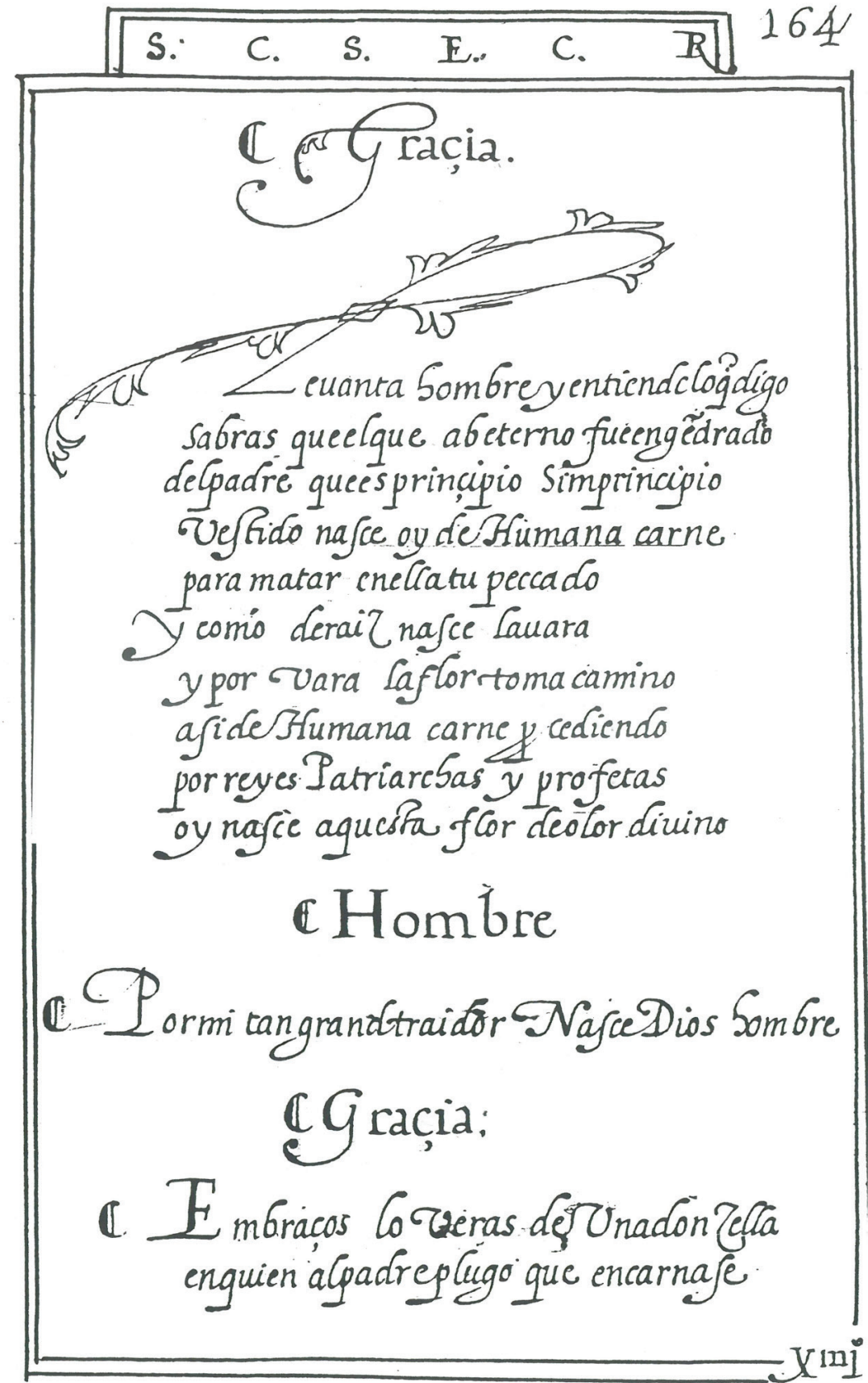

Fig. 2. Francisco Galeas, Representación del nascimiento de Jesuchristo Salvador Nuestro (New York, The Hispanic Society of America, MS. HC380/61 1

[Poesías espirituales y representaciones sacras dramáticas], fol. 164r) 

S.
C. S
E.
C. $\mathbb{R}$.

\section{c. A legria.}

(1) ngañado Giues Silencio sipien fas que baxerzay sobresa me efpantanami porqueno solamente mesabbo conellas perotambien me suelo Sallar enlagumas y sospi= ros, enlos tormentos y muertes delos fustos. bien sentia ef profera que meremia con jigo quando de Sia scgun lamuli tud delosdolores enimi coracon, alegraron serior mi alma tus confolaciones no Sabes tu que Wnodelosfruetos delefpiritu esalegria pues dondeel refidicre como putedo yo faliár

\section{C $\mathfrak{S}$ ilencio.}

1 Porcicrto Lo asdicho muy bien vateconmigo alegriay veras logue def Seas.

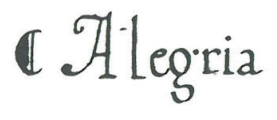

C amos cantando silencio. CSig. C comicnca tualegua concantar rego Uyado.

C Aquientalbien nosa dado cantemos engle dia Mill canpates $M$ alegria.

Fig. 3. Francisco Galeas, Dialogo de dos pastores, el uno llamado Silvano y el otro Alegría (New York, The Hispanic Society of America, MS. HC380/611

[Poesías espirituales y representaciones sacras dramáticas], fol. 177v) 
Sobre la probable fecha del Ms. Galeas, Regueiro y Reichenberger afirman que es «incierta», refiriendo algunas de las postuladas por la crítica según diversos criterios, las cuales parecen inclinarse hacia $1700^{12}$.

En cuanto al contenido, el manuscrito acoge cuatro poemas relativos a la venida de Felipe II a Sevilla en 157013, cuya composición por Galeas en esa fecha resulta imposible, tras el conocimiento con certeza de su fecha de nacimiento en 1567, como nos indica el hallazgo de su partida de bautismo ${ }^{14}$. Regueiro y Reichenberger, al no disponer de este dato fehaciente, lo suponen nacido antes de $1550^{15}$, lo cual ya no se puede mantener. Se trata de cuatro poemas plenamente laudatorios al católico rey Felipe II y al beneficio para Sevilla y su Santa Iglesia derivado de su venida. Si Galeas fue realmente su autor, ¿los compondría a posteriori con el propósito de loar al Rey, evocando esta venida tan celebrada que dejó memoria en la ciudad? No lo sabemos. Más claro de explicar resulta el hecho de que Galeas incluyera bajo su autoría, como el resto de las composiciones recogidas en el ms., la pieza dramática Representación del nascimiento de Jesuchristo Salvador Nuestro (fols. 135r-165r) y de su Introito (fols. 132v-134v), no siendo frutos de su inspiración, como atestigua la segunda de las tres obras sobre el nacimiento de Cristo del MS. B2603, igualmente radicado en la Hispanic Society, hecho advertido por Regueiro y Reichenberger ${ }^{16}$. Conviene tener en cuenta al respecto que el concepto de autoría en aquel entonces no era tan rígido como se iría convirtiendo posteriormente. De dichas obras, del MS. B2603 tuve ocasión de ocuparme en un artículo de 2005, en el que el conjunto de datos barajados me permitió datarlas a finales del segundo tercio del Quinientos e incluso retrasar un poco dicha fecha ${ }^{17}$. El cotejo de la anónima pieza del MS. B2603, Representación del nascimiento de Christo Jesú Salvador Nuestro (fols. 25r-36r), incluido su Introito, con su homónima de Galeas, Representación del nascimiento de Christo Jesú Salvador Nuestro (fols. 25r-36r), muestra que aquella es una copia más deturpada, menos cuidada, abundante en la presencia de los fenómenos dialectales del seseo y ceceo, ciertos olvidos que se corrigen, algunas omisiones, etc., encontrándose bastante alejada de la primorosa y cultista copia del Ms. Galeas ${ }^{18}$. Como indican Regueiro y Reichemberger, aunque la mano de esas tres piezas no sea de un copista profesional, permanece indeterminado que sean autógrafas, es decir, que el manuscrito que las contiene fuera

12. Regueiro y Reichenberger, 1984, vol. I, p. 224.

13. «Para la venida del invictíssimo Rey Phelipe Nuestro Señor» (fol. 73v); «Para la venida del Rey Nuestro Señor» (fol. 74r); «Coplas a la venida del Rey Don Philipe Nuestro Señor, año de mil y quinientos y setenta» (fol. 74v); y «Para la venida del Rey Nuestro Señor» (fol. 75r).

14. Reyes Peña, 2017, pp. 116-122.

15. Regueiro y Reichenberger, 1984, vol. I, p. 223.

16. Regueiro y Reichenberger, 1984, vol. I, p. 224.

17. Reyes Peña, 2005.

18. Más adelante, antes de la edición de la pieza de Galeas, se ofrece una comparación más detallada entre ambas copias. 
de la propia mano del autor ${ }^{19}$. Tras comparar ambas, los citados investigadores, opinan acertadamente que la del Ms. Galeas no pudo ser copia de su homónima del MS. B2603, ni esta tampoco de la de nuestro autor, propugnando que ambas «independently must be based on a third unknown MS.» ${ }^{20}$. Todo lo cual apoya una tradición de la obra anterior a su uso por Galeas.

Y ya sin más preámbulos, tras esta extensa introducción, abordaremos la edición de esas cinco piezas de Galeas sobre el tema del nacimiento de Cristo, de acuerdo con los siguientes criterios y advirtiendo que las ediciones van precedidas de un breve estudio de cada una de ellas ${ }^{21}$.

\section{CRITERIOS DE EDICIÓN}

El afortunado caso de poseer dos versiones manuscritas de la señalada pieza dramática del Ms. Galeas y de su Introito, ha sido un hecho determinante para fijar los criterios de edición en este particular caso. En su cotejo, como acabamos de indicar, se aprecia, en líneas generales, el carácter cultista y la más cuidada, rigurosa y esmerada copia del Ms. Galeas, como muestran los siguientes ejemplos, sin pretensiones de recoger todos los existentes:

a) La terminología y la información suministrada en el encabezamiento del Introito es más precisa y más teatral en el Ms. Galeas (Introito para la comedia y represéntalo uno que suele representar un Simple. Muy gracioso) que en el MS. B2603 (Yntroito. Represéntalo quien suele hazer un simple).

b) En las grafías, el Ms. Galeas mantiene grupos cultos latinizantes, que no conserva el MS. B2603: tractar / tratar, v. 12; conmigo / comigo, v. 18; nescio / necio, v. 45; tractan / tratan, v. 50; divigno [hipercorrección] / divino, v. 50; sancto / santo, v. 56; sanctas / santas, v. 56; cognosçió / conosció, v. 67; cognoscido / conoscido, v. 68; o demonstraçión / demostración, v. 72. También se aprecia algún caso de hipercorrección en el MS. B2603: rreçitasse / rrescitase [forma hipercorrecta], v. 16.

c) El MS. B2603 presenta numerosos casos de seseo (mesclarlas) y ceceo (liziados, perlezía, rriza), ausentes en el Ms. Galeas (mezclarlas, v. 13; y lisiados, v. 32, perlesía, v. 33, risa, v. 35, respectivamente).

d) Por último, también encontramos variantes adiáforas: muy illustres / manificos (v. 1); querría / quería (v. 11); me a comido / me comió (v. 48); proveído / proveyendo, v. 59; seguía / siguía (v. 68), correspondiendo en estos casos la lección en primer término de cada una de las sucesivas parejas al Ms. Galeas.

19. Regueiro y Reichenberger, 1984, vol. II, p. 740.

20. Regueiro y Reichenberger, 1984, vol. I, p. 224.

21. Para el mismo, he recurrido a la presentación que hice de dichas piezas en 2017 , si bien en algunos casos he introducido ciertas adiciones y variantes. 
En la pieza que lo sigue, el Ms. Galeas continúa manteniendo grupos cultos latinizantes, que no se conservan en el MS. B2603; no hay casos, salvo alguna excepción, de seseo ni ceceo, tan frecuentes en el testimonio del MS. B2603; y, sobre todo, presenta mejores lecciones, en las que aquí no podemos detenernos, y dos adiciones: los términos «como matachines y juegan al auejón» (fol. 148v) que concretan y detallan aún más una acotación; y el verso «del Padre que es prinçipio sim prinçipio» (fol. 164r) que completan semántica y métricamente una estrofa, sin que por su falta en el MS. B2603 quede estragado el sentido. Frente a ellas, el Ms. Galeas presenta la omisión de una frase del MS. B2603 («y el ynsasiable amor que me tienes: tu grandeza», fol. 29v), cuya falta tampoco estraga el sentido en aquel22.

Debido a ello y movida por el deseo de poner en evidencia ese carácter cultista en la escritura de Galeas, que su copista reproduce, el cual no resulta extraño por la muy cuidada formación cultural del cartujo, he optado por respetar dichos cultismos en la edición que ofrezco, si bien a veces encontramos ciertas vacilaciones (Prophecia / Profecía, que en este caso uniformo por Prophecia, debido a su mayor número de incidencias; assí / así, aucthoridad / auctoridad, Essa / Esa y otras oscilaciones que mantengo), rechazando en nuestra edición la modernización, ya presente en bastantes de dichos términos en la versión del MS. B2603. No obstante, para facilitar la lectura desarrollo las abreviaturas, sin advertirlo; sigo las normas actuales en la puntuación, acentuación, empleo de las letras mayúsculas y separación de palabras, respetando las contracciones frecuentes de la época (deste, della, dese...); modernizo grafías antiguas (sustituyo la grafía x por $j$ y la grafía i por $j$ cuando esos son sus respectivos valores; escribo con $h$ - el verbo haber, así como otros términos que modernamente la requieren, acomodo la $b$ y la $v$ a las exigencias actuales; sustituyo la ç por c y la z por $c$, cuando este es su valor, etc.); transcribo la vocal $i$ larga [j] por $i$, y la grafía $u$ por $v$, cuando tiene valor consonántico, y $v$ por $u$, cuando su valor es vocálico. Como es habitual, se colocan entre corchetes las adiciones y se sitúan entre paréntesis los parlamentos recitados en Aparte.

22. He aquí ambos párrafos en uno y otro testimonio: Ms. Galeas: «Profheçía, hermana mía, graçiosamente as mostrado tu grandeza en dezir tanto en tam poco y el amor en la alegría con que lo das a entender, y con muy grande razón, pues sabes que soy venida para cumplir tu palabra» (fol. 145r) / MS. B2603: «Profecía, hermana mía, graciosamente as mostrado tu grandeza y el ynsasiable amor que me tienes: tu grandeza en dezir tanto en tan po[co] y el amor en el alegría con que lo das a entender, y con muy grande razón, pues sabes que soy venida para cunplir tu palabra» (fol. 29v). 


\section{EDICIÓN DE LOS TEXTOS}

\section{Para la festividad del nascimiento de Nuestro Salvador y paces fechas en la discordia entre Fortaleza y Flaqueza}

EnCABeZAMIENTo: Para la festividad del nascimiento de Nuestro Salvador y paces fechas en la discordia entre Fortaleza y Flaqueza (fols. 95v-103v).

FIGURAS: Fortaleza y Flaqueza, caracterizados como pastores, cuyos signos de rudeza y comicidad en el lenguaje y actuación, propios de su condición pastoril, se reducen a los versos 70-79 y 110-147, correspondientes estos últimos a la pelea entre ambos. Conviene tener en cuenta que son dos personajes alegóricos, que simbolizan dos conceptos, a los que Galeas dota de entidad dramática encarnándolos en dos pastores, personajes muy ligados en la tradición bíblica y teatral al drama navideño, en el que se filia la pieza. En nuestro caso, no se trata de los típicos pastores rústicos del teatro primitivo, sino de pastores «sabios» o «doctos» que también se encuentran en él. No obstante, el autor les permite asomar algunos rasgos de aquellos, que contribuyen a humanizarlos más ante los espectadores, como sucede con el pasaje de la riña entre ambos. La caracterización como masculinas - pastores - de figuras alegóricas de género gramatical femenino -Fortaleza y Flaqueza-, que se observa en Galeas, aparece también en las tres piezas del MS. B2603, como pusimos de manifiesto en su estudio ${ }^{23}$, contrastando, en cambio, por citar un ejemplo, con la tendencia que predomina en el Códice de Autos Viejos, donde dichas figuras se suelen caracterizar, aunque no siempre, de acuerdo con su género gramatical. Es cierto que este tipo de personajes alegóricos lo permitía, pero, sobre todo, de esta forma se salvaba el problema de la representación de figuras dramáticas femeninas. Hay que tener en cuenta el ámbito de representación de esas obras. Desconocemos, si las de Galeas se llegaron a representar -al menos con esa intención las compuso-, pero, si lo hicieron, sería probablemente en el ámbito conventual y por actores amateurs, como sucedía en el ámbito catedralicio. Mientras en este suponíamos que serían los niños y mozos de coro, en el convento esos actores serían los novicios o allegados más jóvenes, que también asumirían la representación de personajes femeninos. Si hubiera sido así, ello ofrece una clara muestra de cómo el ámbito de representación condiciona la escritura y la puesta en escena de las obras. A ellos, habría muy plausiblemente que añadir un número indeterminado de participantes en la representación de esta pieza que -suponemos - cantarían el villancico de apertura y los villancicos posteriores, cuya función es comentar la acción representada. ¿Qué harían los actores mientras se interpretaban estos villancicos? ¿Permanecerían estáticos sobre la escena? Unos villancicos, además, que son una interpelación directa al espectador: los dos pastores no oyen -hacen que no oyen- dichos versos cantados. Se produce una ruptura de la convención teatral que hace partícipe al espectador en la representación. 
FORMA EXPRESIVA, EXTENSIÓN Y MÉTRICA: Pieza escrita en verso: 248 Vv., agrupados en 45 quintillas octosilábicas con rima consonante y el mismo esquema $(A B B A B)^{24}$. Dos villancicos de tres versos octosílabos con sus propias rimas y el mismo esquema (ABB) abren y cierran la pieza; y otros seis aparecen distribuidos entre las quintillas, resumiendo de forma muy concisa el contenido de la serie de quintillas que los preceden: cuatro de tres versos octosílabos con rima consonante y la misma disposición (ABB), otro de tres versos, el segundo quebrado (8A4B8B); y otro de dos versos octosílabos pareados $(8 \mathrm{~A} 8 \mathrm{~A})^{25}$. Es decir, se trata de una pieza donde se combinan y articulan a la perfección el contenido y la forma, la recitación y el canto.

ARgUMENTO: El villancico inicial sintetiza el contenido de la pieza (vv. 1-3). La obra escenifica una disputa entre los personajes Fortaleza y Flaqueza cuando el segundo desea hacer las paces con el primero, que se resiste por sus opuestas naturalezas. Sin embargo, Fortaleza queda convencida al argumentar Flaqueza que ya es posible, debido a la encarnación del Verbo divino en virginales entrañas, pues con la carne el Verbo pagará a Dios la deuda del hombre. Ambos personajes finalizan la pieza, dirigiéndose a la recién parida para ofrecerle la vida. Un villancico en loor de la encarnación de Cristo pone fin a la obra (vv. 246-248).

Si bien puede sorprender el triunfo del personaje «débil» sobre el «fuerte» en ese debate dialéctico entre Fortaleza y Flaqueza, que es además quien adoctrina, en contra de lo que cabría esperar, no podemos olvidar que es debido al cambio de identidad que ha operado en ella el nacimiento de Cristo, motivo que se celebra; es decir, a la nueva carta de naturaleza de la que esta venida la ha dotado. Por otra parte, en la pieza de Galeas el personaje Fortaleza no encarna la Fortaleza divina, sino a la tercera de las virtudes cardinales de la doctrina católica, que son hábitos del ser humano que disponen al entendimiento y a la voluntad para obrar según el juicio de la razón, iluminada por la fe, para que esta escoja los medios más adecuados al fin sobrenatural del hombre. Esa Fortaleza divina es la que aparece, en cambio, como personaje en la Farsa del sacramento llamada La esposa de los Cantares (LXXIII del denominado Códice de Autos Viejos, compilación de piezas de hacia 1550-1575), donde es un don sobrenatural, que Cristo entrega al Alma arrepentida para que sea firme en su lucha contra el Demonio en lo que le resta de vida terrena, como muestran estos versos:

24. A la formada por los vv. 236-240, le faltan los dos primeros versos, que hemos contabilizado. En los esquemas de rimas, empleo la letra mayúscula, para indicar la consonancia y la minúscula para la asonancia.

25. Como lo emplea Galeas, utilizamos el término villancico en el sentido de canción breve, frecuentemente con estribillo, con independencia de la forma estrófica que presente. 
XPO

Y en pago de la firmeza [la del Alma] que as tenido tan cabal te daré mi fortaleza, qu'es don sobrenatural (LXXIII, t. III, p. 226, vv. 409-412)26.

Y la Fortaleza, que trae noticias del cielo, en diálogo con el Cuerpo se define a sí misma en estos otros:

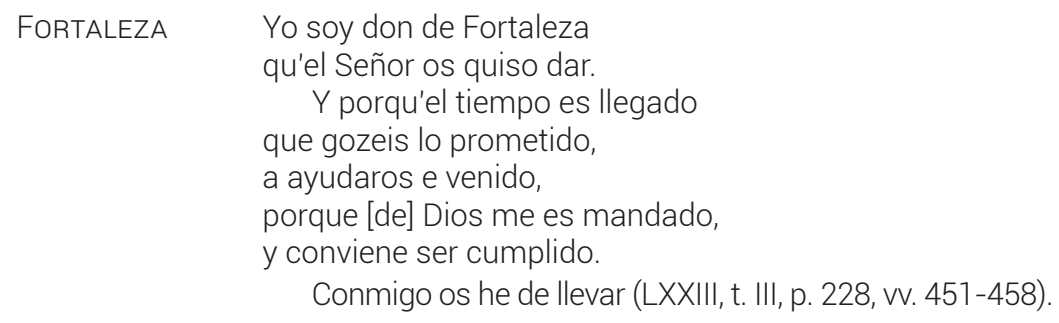

GÉNERO: Auto alegórico en su tema y personajes, donde su autor aborda, proclama y adoctrina sobre el misterio de la unión hipostática y la encarnación en vientre virginal de la Segunda Persona de la Santísima Trinidad.

TEATRALIDAD: Enfrentamiento fundamentalmente dialéctico entre dos personajes de opuesta naturaleza que llega incluso a las manos (vv. 118-142), resolviéndose cuando Flaqueza triunfa sobre Fortaleza y esta cede a sus peticiones.

FINALIDAD: Pieza para la celebración del nacimiento de Cristo con propósito doctrinal sobre el misterio de la unión hipostática y la encarnación del Verbo Divino por amor en el seno virginal de Nuestra Señora, con sus benéficas consecuencias para el Género humano.

He aquí el texto:

Para la festividad del nascimiento de Nuestro Salvador y paces fechas en la discordia entre Fortaleza y Flaqueza

Dos pastores differentes hacen a $\operatorname{costa}^{27}$ de Dios las paces entre los dos.

ForTALEZA Flaqueza, di, por tu fee, ¿por qué te burlas conmigo? Tú no eres buen testigo,

26. Las citas del Códice de Autos Viejos corresponden siempre a la edición de Léo Rouanet, Colección de autos, farsas y coloquios del siglo XVI, 1901 (ed. facs. 1979).

27. v. 2 a costa: «metafóricamente vale trabajo, fatiga, sudor. Y así se dice a costa de...» (Aut.). 
que yo no soy ni lo fue ${ }^{28}$

a una jamás contigo ${ }^{29}$.

La hormiga, ¿quién la vio

atreverse al elefante?;

y a la serpiente volante ${ }^{30}$, ¿qué avecilla se atrevió

a ponérsele delante?

$Y$ parida la leona

y sus cachorros guardando,

o la presa destrozando,

dime, ¿cuál es la persona

que a ella se va llegando?

¿Piensas tú que he de sufrir

que me quieras conversar

y a mis parejas andar ${ }^{31}$

tú que acostumbras huiir

lo que yo suelo esperar?

Yo soy el que solo alcanzo

lo que tú para ti no alcanzas:

amas solas las bonanzas,

yo en los peligros me lanzo

y allí hallo mis holganzas.

Tú desmayas de cobarde,

yo me esfuerzo de esforzado,

y al peligro señalado

lo que tú vienes de tarde

vengo yo de apresurado.

\section{Villancico}

A pastor tan denodado

que en los peligros se lanza

se debe toda alabanza.

28. v. 7 fue: forma latino-vulgar y tardía de la primera persona del singular del perfecto acabado del verbo ser, pero con valor semántico de ir. Alvar y Pottier incluyen fue en el paradigma evolutivo de la forma clásica fui, primera persona del perfecto acabado del verbo ser (1993, p. 265).

29. vv. 7-8 no soy ni lo fue / a una, ir a una dos o más personas: «loc. verbal: procurar de común acuerdo la consecución de un mismo fin» (DRAE); es decir, en nuestro caso los vv. 7-8 significan 'no ser dos personas conformes ni parecidas ni en la condición ni en las costumbres, por lo que no se entenderán o convendrán fácilmente'.

30. v. 11 serpiente volante, víbora volante: «especie de coleóptero de una pulgada de longitud, de color pardo rojizo, de antenas muy largas», acepción que se emplea en Andalucía (DRAE).

31. v. 21 «... vale ir iguales o sobrevenir juntas algunas otras cosas, o ser semejantes en alguna prenda u habilidad» (Aut., s. v. pareja). 
FLAQUEZA
Noble pastor Fortaleza,

dime, si fueres servido, ¿cuándo jamás has sentido que fuese yo a tu grandeza en algo descomedido?

Siempre te fui servidor en público y en secreto, y no soy tan indiscreto que no tenga por señor a quien todo está subjeto.

No me puedes tú decir de tu poder espantable ${ }^{32}$ cuanto sé que es inefable ${ }^{33}$, ni otro que yo sentir mi flaqueza miserable.

Mas, si licencia me das para decir lo que siento sin mucho entretenimiento, la causa en breve sabrás de aqueste mi atrevimiento.

Pues el flaco pastorcico muestra en sí tanto contento, alto tiene el pensamiento.

Flaqueza, mira por ti, que palabras regaladas, halagüeñas, rebozadas, más dolor causan en mí que crüeles puñaladas.

No pienses que por crïanza

ni por otro cumplimiento he de hacer movimiento, que no dice bien mudanza en quien tiene buen assiento ${ }^{34}$.

No tuviera por offensa ${ }^{35}$ que, a la rasa y al desnudo ${ }^{36}$,

32. v. 48 espantable: «excelente, admirable, maravilloso, sumamente portentoso y grande, y digno de asombro» (Aut.).

33. v. 49 inefable: «lo que es incapaz de que se explique o que se hable de ello con propriedad», por exceder nuestra capacidad (Aut.).

34. v. 69 assiento: en el sentido de «el cuerdo, maduro y prudente, de acreditada experiencia, y de conocido juicio e inteligencia» (Aut.).

35. v. 70 offensa: «daño, injuria o agravio que se hace a otro de palabra o de obra» (Aut.).

36. v. 71 a la rasa y al desnudo: locuciones adverbiales con el sentido de 'descubiertamente, a bote pronto, de manera improvisada, sin rodeos'. 
pidieras a puncto $\mathrm{crudo}^{37}$

que yo para tu deffensa

me pusiera por escudo.

Mas ciertas buenas razones

con no sé qué mansedumbre,

porque me dan pesadumbre,

pagarlas con torniscones ${ }^{38}$

lo tengo muy de costumbre.

\section{Villancico}

Por estar puesto en la cumbre,

no quiere el pastor oír

lo que le importa sentir.

FLAQUEZA

FORTALEZA

Si yo no voy muy a ciegas

o veo como tras redes,

ya me has hecho las mercedes,

pues de una forma las niegas

y de otra las concedes.

FLAQUEZA

Di, Flaqueza, ¿cómo assí?

Porque, como yo lo pido,

bien sé que estoy despedido;

mas, como te agrada a ti,

ya lo tienes concedido.

Y, pues licencia me das, sabrás...

FORTALEZA ¡No quiero saber cosa contra mi querer!

FLAQUEZA

Pues mira, saberla has

FORTALEZA

a placer o desplacer.

Rapacejo pastorcillo, ¿conmigo queréis burlaros?

Yo tengo de lastimaros.

FLAQUEZA

¡Lastimaréis vos un grillo,

que a mí no osaréis llegaros!

FORTALEZA

¿No verse en tu compañía desmayo y debilidad,

y fuerza y estabilidad

FLAQUEZA que están de la parte mía? Assí es grande ${ }^{39}$ verdad.

37. v. 72 puncto crudo: «A punto crudo, o a tiempo crudo. Modo de hablar con que se da a entender que se llegó a alguna parte, o se solicitó alguna cosa tarde y sin oportunidad, en mala ocasión y coyuntura, fuera de la sazón» (Aut., s. v. crudo).

38. v. 78 torniscones, torniscón: «golpe que se da en la cara con el revés de la mano» (Aut.).

39. v. 107 En el ms. grand (fol. 98v), que he corregido por necesidades métricas. 


\begin{tabular}{|c|c|c|}
\hline FORTALEZA & $\begin{array}{l}\text { Luego una es la victoria } \\
\text { de razón y de derecho. }\end{array}$ & \\
\hline FLAQUEZA & $\begin{array}{l}\text { Partido será este hecho, } \\
\text { que tú llevarás la gloria } \\
\text { y yo llevaré el provecho } 40\end{array}$ & 110 \\
\hline FORTALEZA & ¿Es posible que me esperas? ${ }^{41}$ & \\
\hline FLAQUEZA & Es posible que te espero. & \\
\hline FORTALEZA & ¿Al león bravo, el cordero42? & 115 \\
\hline FLAQUEZA & $\begin{array}{l}\text { Al león y a otras fieras } \\
\text { puedo esperarlas, si quiero. }\end{array}$ & \\
\hline FORTALEZA & ¡Pues a las manos, pastor! & \\
\hline FLAQUEZA & ¡A las manos y a los pies! & \\
\hline FORTALEZA & $\begin{array}{l}\text { ¡Más crïanza, descortés, } \\
\text { que vos por ganar honor } \\
\text { veréis cómo lo perdéis! }\end{array}$ & 120 \\
\hline FLAQUEZA & Ya no es possible perder. & \\
\hline FORTALEZA & Pues no es possible ganar. & \\
\hline FLAQUEZA & $\begin{array}{l}\text { Possible es para mostrar } \\
\text { que, pues vos tenéis poder, } \\
\text { a mí no puede faltar. }\end{array}$ & 125 \\
\hline FORTALEZA & $\begin{array}{l}\text { ¡No hay ventaja cognoscida }{ }^{43}, \\
\text { vamos a brazo partido! }\end{array}$ & \\
\hline FLAQUEZA & $\begin{array}{l}\text { ¡Vamos! Ternás entendido } \\
\text { que mi fuerza está crescida } \\
\text { y tu poder no ha crescido. }\end{array}$ & 130 \\
\hline FORTALEZA & ¡Suso!45, los brazos assidos. & \\
\hline FLAQUEZA & ¡Suso!, pues que tú lo quieres. & \\
\hline FORTALEZA & ¿Qué harás? & \\
\hline \multicolumn{3}{|c|}{$\begin{array}{l}\text { 40. vv. 110-112 'De este enfrentamiento entre ambos, sacaremos ventaja los dos: tú -Fortaleza- te } \\
\text { Ilevarás la gloria y yo -Flaqueza- me llevaré el provecho'. } \\
\text { 41. v. } 113 \text { '¿Es posible que te atrevas a aguardarme para luchar conmigo?' } \\
\text { 42. v. } 115 \text { Al león bravo: bajo la tradicional imagen del «león fiero», es muy posible que subyazga implícita } \\
\text { una referencia a la tradicional iconología de la figura de la Fortaleza: «Mujer armada y vestida de color } \\
\text { leonado, lo que simboliza la fortaleza por su semejanza con el León. Se apoya esta mujer en una colum- } \\
\text { na, porque de los elementos de un edificio este es el más fuerte y el que sostiene a los otros. A los pies } \\
\text { de la figura que decimos se ha de ver un León en posición yacente...» (Ripa, Iconología, t. I, p. 437). Sin } \\
\text { duda, Galeas por su labor como artista plástico conocía a la perfección la iconología de este y del resto } \\
\text { de los personajes alegóricos presentes en sus obras. / el cordero: las connotaciones múltiples del cor- } \\
\text { dero y sus implicaciones mesiánicas son más que oportunas en la obra, dada la temática de la misma. } \\
\text { 43. v. } 128 \text { cognoscida: 'conocida'. } \\
\text { 44. v. } 129 \text { a brazo partido: «Frase adverbial, que denota el modo de contender, luchar y batallar uno con } \\
\text { otro con los brazos, igualmente, y sin otras armas ofensivas» (Aut., s. v. brazo). } \\
\text { 45. v. } 133 \text { ¡Suso!: ' ¡Vamos!'. Como indica Covarrubias, «De esta palabra sus y suso usamos cuando que- } \\
\text { remos dar a entender se aperciba la gente para caminar o hacer otra cosa» (s. v. sus). }\end{array}$} \\
\hline
\end{tabular}


FLAQUEZA

Lo que hicieres.

FORTALEZA

FLAQUEZA

Pues, mira, no des gemidos.

FORTALEZA

No daré, si no los dieres.

Flaqueza, ya no haya más,

que me cansas. jDejamé! ${ }^{46}$

FLAQUEZA Ni un puncto te dejaré,

si primero no me das

lo que yo supplicaré.

FORTALEZA

Dime, ¿qué quieres, hermano?

FLAQUEZA

Que no te estrañes ${ }^{47}$ de mí.

FORTALEZA ¿Y qué más?

FLAQUEZA

Que, pues en ti

hay poder tan soberano,

no me deseche de sí. ${ }^{48}$

FORTALEZA Hágase todo a tu grado, engrandescido pastor.

Pero dime, por mi amor,

¿quién te ha comunicado este divino favor?

Que, pues conmigo has podido que soy de tanta grandeza,

no te llamarás Flaqueza,

mas ternás por apellido

«quien pudo con Fortaleza».

\section{Villancico}

En lucha ganó Jacob nombre de grande grandeza y así lo ganó Flaqueza ${ }^{49}$.

FLAQUEZA

Pues que licencia no falta, sabrás que el que nos crió en su consejo acordó

46. v. 139 ¡Dejamé!: término con dislocación de acento, pedido por la métrica y por la rima.

47. v. 144 estrañes, extrañar: «apartar y echar de sí y de su comunicación a alguno, tratándole como ajeno y no conocido. o contrario» (Aut.).

48. v. 147 El poder tan soberano de Fortaleza acoja a Flaqueza y no la 'menosprecie o desestime'. 49. vv. 158-160 Los dos primeros versos del villancico evocan la lucha del patriarca Jacob con el Ángel durante toda la noche, al que acaba venciendo, y este le cambia el nombre de Jacob por el de Israel: «En adelante no te llamarás Jacob sino Israel; porque has sido fuerte contra Dios y contra los hombres, y le has vencido» y lo bendice (Génesis, 32, 25-31, la cita en vers. 29), como le ha ocurrido a Flaqueza al vencer a Fortaleza (vv. 153-157). Precisamente, este episodio bíblico de la lucha de Jacob con el Ángel, da título al «Auto XI» del Códice de Autos Viejos: XI. Aucto de la lucha de Jacob con el Ángel, que dramatiza dicho episodio en los vv. 342-391 (Rouanet, 1901, t. I, pp. 182-199, pp. 194-195). 
una junta ${ }^{50}$ la más alta

que se verá ni se vio.

Divina naturaleza

por hombres tanto se humana

que, por unión soberana,

en un supuesto ${ }^{51}$ su Alteza

está con natura humana.

De suerte que el impassible ${ }^{52}$, el eterno e inefable lo puedes ver conversable, humano, humilde y passible ${ }^{53}$ en esta unión admirable.

Aquí subió humanidad lo que más pudo subir y, queriéndola assí unir, descendió divinidad cuanto se sufre abatir ${ }^{54}$.

Y pues Dios tanto subió cosa tan baja consigo, paciencia ternás, amigo, que de hoy más andaré yo a las parejas contigo.

\section{Villancico}

\section{El león traerá consigo al cordero por amigo y compañero.}

FORTALEZA

Ya que me tienes rendido y a tu servicio obligado, quiero ser más informado deste bien engrandescido tan de gracia al hombre dado.

FLAQUEZA

La eterna sabiduría, que por quién es nos amó, de amor vencido ordenó 55

50. v. 164 junta: 'unión'

51. v. 169 un supuesto: «término de Filosofía, y, usado como substantivo, es la individualidad de la substancia completa, e incomunicable» (Aut.).

52. v. 171 impassible, adjetivo sustantivado: «incapaz de padecer» (Aut.)

53. v. 174 passible: «lo que puede o es capaz de padecer» (Aut.).

54. v. 180 abatir: 'descender, bajar'. En los vv. 161-180, Flaqueza aborda con sencillez el inexplicable misterio de la unión hipostática, que en la teología cristiana designa la unión de las dos naturalezas, divina y humana, en la persona de Cristo.

55. ordenó: el ms. ordenado (fol. 102r), término que no respeta la rima y deja sin verbo en forma personal la oración principal, que he corregido. 
FORTALEZA

FLAQUEZA que lo que el hombre debía

pagase el que lo crió.

Y, como Dios, el castigo,

el padescer y morir

no podía rescebir,

unió la carne consigo

que no lo puede huirr.

$Y$ para tan alto bien

por un dichoso camino

encarnó el Verbo divino.

¿Dios encarnado? ¿Y en quién?

En quien para Dios convino.

En virginales entrañas

de una divina doncella,

tan agradescida y bella 56

en quien Dios hizo hazañas

que no hiciera sin ella.

En carne quiso nascer

para en ella a Dios pagar

y al hombre desadeudar,

porque en Dios el padescer

sin carne no hubo lugar.

De modo que Dios del hombre

en Dios se hizo pagado

y el hombre fue libertado

con el divino renombre

que Dios del hombre ha tomado.

\section{Villancico}

¡Bendito sea tal nombre, hombre y Dios y Dios y hombre!

Pues me tienes instruïdo de grandeza tan subida, vamos a ver la parida y al niño recién nascido y ofrezcámosle la vida;

que para tan gran señor

y tan divina doncella

la vida es poco ofrescella,

si no la accepta el amor

que nos tiene Él y Ella.

56. v. 21 bella: en el ms. tam bella (fol. 102v), que he corregido para recuperar la ortometría del verso. 
que hicieron estos días

con dulces lamentaciones

las celestes hierarquías ${ }^{57}$.

Celébrese esta grandeza

en lo divino y humano,

que en ella no hubo otra mano,

sino solo la riqueza

del amor del Soberano.

\section{Villancico}

Por amores del humano,

humano nascéis, Señor.

¡Bendito sea vuestro amor!

Laus Deo.

\section{Comedia intitulada Triunfo de Pobreza contra Riqueza}

Encabezamiento: Comedia intitulada Triunfo de Pobreza contra Riqueza (fols. 110r-132r).

Figuras: Mundo, Riqueza, Pobreza, Simplicidad, Sosiego, Solicitud, Curiosidad, Dos Truhanes, Ángeles, Pastores.

FORMA EXPRESIVA, EXTENSIÓN y MÉTRICA: En prosa, con una extensión aproximada de 653 líneas, más 68 vv. cantados, más una «letra» de 3 vv. ${ }^{58}$, más un breve texto latino cantado. Escrita con un lenguaje sencillo, la prosa aparece seccionada por una serie de versos cantados: dos villancicos de 3 versos (8A8B8B) ${ }^{59}$; un villancico de 6 versos (8A4A:8A8A4A:8A); un villancico de 4 versos (6a6B6a6B); un villancico de 3 versos (9A5A:9A); un villancico de 2 versos (11A11A); un villancico de 12 versos (6A6B6A6B:6B6C6A6C:6C6B6A6B); un villancico de 7 versos (8-7A:8B8B8B8A:7A); dos villancicos de 4 versos con la misma disposición de rimas (6-6A6-6A y 7-7A7-7A); un villancico de tres versos (6a6a7a); un villancico de 5 versos (8A6b6b6b6A); y cuatro tercetos encadenados. En total, un conjunto de 68 versos cantados, a los cuales hay que añadir una «letra» de 3 versos octosílabos (ABB) y un breve texto cantado en lengua latina, presente en las ceremonias litúrgicas del tiempo de Adviento, tejido con frases de inspiración profética: «Veni,

57. vv. 236-240 Quintilla incompleta por la falta de los dos primeros versos, que complementarían su sentido.

58. «letra»: «el mote ['sentencia breve, que esconde algún secreto u misterio, que necesita aclaración'] que explica el cuerpo de una empresa» (Aut., s. v. letra y mote).

59. En los esquemas de rimas, empleo la letra mayúscula, para indicar la consonancia y la minúscula para la asonancia. 
Domine, et noli tardare. / Ostende faciem tuam, et salvi erimus» (La segunda parte localizada en Sal, 79, 4, 8 y 20). La variedad de las combinaciones del número de versos, junto a la variedad en el número de sílabas, ofrece una riqueza rítmica que ahondaría en la espectacularidad de la puesta en escena de la obra.

ESTRUCTURA: La pieza está segmentada en Cuatro Partes, separadas por el vacío de personajes sobre la escena, muestra evidente del intento de dar cuerpo a la estructura de la obra dramática. Esta segmentación, aunque coincida en su número con el de las cuatro jornadas de comedias de la época, denominación que Galeas le atribuye a la obra, no la estimo relacionada con ellas, porque en otras piezas también divididas en Partes, su número no es de cuatro sino de tres (La historia de cuando Abraham echó de casa a Ismael y Agar, su madre, fols. 105r-109v) o seis (Representación del nacimiento de Jesucristo Salvador nuestro, fols. 135r-165r). Más la considero, si es que su ámbito de representación fue el conventual, como un deseo del autor de segmentar la estructura de la obra en pequeñas unidades cerradas para su sucesiva representación entre los intermedios del rezo de las horas canónicas, que eran observadas con especial atención y cuidado en las comunidades monásticas. Recordemos al respecto estas elocuentes palabras sobre su importancia en la formación de los cartujos, debidas al hermano de Galeas, el abad Alonso Sánchez Gordillo, donde nos dice que al llegar al Convento de las Cuevas para ser recibido como religioso, el pretendiente a ello era

examinado en latinidad, que demás ciencias no se procura $y$, durante el año de noviciado, el Superior le asignaba un Maestro para que le enseñara las costumbres de la Orden y las ceremonias particulares y a cantar y rezar el Oficio y Horas Canónicas y que tome de memoria el Salterio para cantar en el Coro, expecialmente para Maytines que se dicen sin luces, y se cantan los psalmos de memoria (Sánchez Gordillo, Svmaria relación del insigne Monasterio de Santa María de las Cuevas de Sevilla [...], 2003 [1663], p. 369) ${ }^{60}$.

ARGUMENTO: Riqueza, sabedora de la venida del más alto y más poderoso señor que tiene la tierra, pide ayuda a su padre el Mundo para, con su favor, aparejarle la más alta y la más rica posada. El Mundo, conocedor de que esa misma noche su hija Pobreza recibe en ese mismo lugar a dicho huésped, le aconseja que haga dos cosas: preparar un rico aposento e ir a visitar a su hermana Pobreza para cerciorarse de la noticia. Pobreza, que entra en escena acompañada por sus hijos Simplicidad y Sosiego, les comunica la buena nueva de que «el Príncipe soberano, hijo del eterno Padre, Dios de Dios y Señor nuestro», ha venido del cielo y se aposentará en su casa, conminándolos a preparar su humilde posada. Riqueza pide ayuda a sus criados, Solicitud y Curiosidad, para aderezar su majestuosa posada y estos le ofrecen distintas galas y entretenimientos, entre ellos la actuación de dos Truhanes, que entran en escena y le dan cuenta de sus habilidades. Riqueza los acepta y 
se dirige a visitar a Pobreza. Esta la recibe junto a sus hijos y responde a sus preguntas sobre la posible venida y la identidad del huésped que espera, argumentando a su hermana las razones por las que elegirá su morada. Riqueza, "corrida», la abandona y se dirige a aguardar en su suntuoso aposento al mismo señor que ella. Pobreza exhorta a sus hijos a ver al «Deseado» y una cortina se abre y descubre el nacimiento. Ángeles y Pastores lo acompañan, cantando y tocando instrumentos. Pobreza y sus hijos se dirigen al nacimiento y, acabado el canto, se cierra la cortina, quedando todo cubierto por ella.

GÉNERO: Auto alegórico celebrativo del nacimiento de Cristo para representar el día de Nochebuena. Su adscripción en el encabezamiento al género de «comedia» es aleatoria.

TEATRALIDAD: La tensión dramática entre los dos protagonistas, opuestos por naturaleza, no alcanza grandes cotas, pues es bastante suave. Galeas se muestra dueño de la puesta en escena, como revelan las acotaciones explícitas, a las que habría que sumar las marcas presentes al respecto en las acotaciones implícitas que se aprecian a lo largo del texto. En las acotaciones explicitas se advierte: control sobre las entradas y salidas de los personajes de escena, el número y la caracterización de los mismos -alusión a su carácter alegórico, que lleva implícita una forma de comportamiento escénico y una caracterización (maquillaje, vestuario) concreta-, el contraste frente a estos personajes alegóricos de los Truhanes, los fragmentos cantados, las indicaciones corporales («arrodillarse») y la espectacular puesta en escena final con la presencia del Nacimiento (diferentes niveles de colocación de los personajes, cortina, etc.)... En las acotaciones implícitas aparecen marcas de los distintos sistemas de signos escénicos. Sin pretensiones de exhaustividad, señalamos algunas de ellas:

RIQUEZA.- [...] Mi señor, dame las manos, besarlas he de rodillas / MUNDo.- Levanta, hijo, levanta, y [...].

CURIOSIDAD.- Espera, Solicitud, espera, que tengo de ver dó pongo los pies, porque esta subida no está nada buena. Y, si por aquí la Riqueza ha entrado, muy justo sería que se aderezase con otro cuidado, otra limpieza y más policía. [...]

CURIOSIDAD.- Que el primero paso della es más alto que el segundo casi, casi una pulgada. [...]

CURIOSIDAD.- Señora, dadme la mano. / RIQUEZA.- ¡Dejadme, que yo subiré! [...]

RIQueZA.- Curiosidad, date priesa, que se va haciendo tarde. [...]

RIQUEZA.- [...] Entremos a la posada, que en tanto que se adereza me tengo de ir a ver con la Pobreza. / SolicITUD.- ¡Vamos mucho en buena hora! [...]

SOSIEGO.- ¡Silencio, silencio!, que viene gente de fuera. [...]

PobreZA.- ¡Muy bien venida seáis, mi señora! ¿Qué novedad es aquesta de venir a mi posada? 
Todo ello evidencia el conocimiento por Galeas de los recursos escénicos y de su funcionalidad.

FINALIDAD: Propósito celebrativo y aleccionador, con motivo del nacimiento de Cristo. Esta finalidad catequística justifica en parte la inclusión de la escena de los Truhanes, dos personajes reales de la vida cotidiana del auditorio, que introducen un episodio cómico en la escena. Su presencia en el desarrollo de la acción proporciona un momento muy ágil y cotidiano, fácilmente reconocible por el público de la época, que se ve potenciado aún más por el contraste con el tono alegórico-religioso de la pieza y de sus personajes, y contribuye a acercarla a los espectadores ${ }^{61}$.

He aquí el texto:

\section{Comedia intitulada Triunfo de Pobreza contra Riqueza \\ En la Primera parte se introducen Mundo y Riqueza ${ }^{62}$.}

RIQUEZA.- Señor y padre mío, si de la generosidad de tu ánimo y del grande amor que me tienes no hobiera hecho experiencia, según de tus favores me hallo obligada, no te osara supplicar lo que pretendo; mas, estando con tal seguro de tu parte, allego ${ }^{63}$ sin temor, de tu amor confiada, a pedirte una cosa que de suyo es tan justa que ni yo puedo dejar de pedirla ni tu bondad debe negarla.

61. Véase al respecto el interesante artículo de Alfredo Hermenegildo, 2009.

62. Mundo y Riqueza: Cesare Ripa ofrece dos descripciones de Mundo en su Iconología, la primera procede del Libro Primero de la Genealogía de los Dioses de Boccaccio y la segunda de los Jeroglíficos Comentados de Pierio Valeriano. Es de suponer que Galeas pudo tener en mente a ambos autores, pero me inclino a pensar que la imagen de P. Valeriano se acerca más a la imaginería del fraile cartujo (la imagen de Boccaccio se establece a partir del dios Pan), con el que compartiría, además, título de libro. La obra de Pierio Valeriano suele ser considerada como la gran recopilación del saber sobre el simbolismo en el Renacimiento. Se publicó en Basilea (1556) y fue bien conocido en la España del siglo XVI. Esta es su descripción: «Hombre apoyado sobre sus pies, dando impresión de gran firmeza y estabilidad, que aparece vestido con una túnica de diversos colores y llevando en la cabeza una gran bola o globo esférico, que ha de ser de oro. Se pinta así para mostrar la fortaleza de la Tierra. La túnica de diversos colores simboliza los cuatro Elementos, así como las cosas por ellos engendradas, con cuya multitud y variedad toda la Tierra se reviste. Y en cuanto a la bola esférica, de oro, simboliza el Cielo y su movimiento circular» (Ripa, Iconología, t. II, pp. 100-102, la cita en p. 102). Ripa ofrece también dos imágenes de la Riqueza, la primera procedente de la descripción realizada por Aristófanes en su comedia Pluto. En ella, se pinta como una «mujer muy vieja y ciega que aparece vestida con túnica de oro». Esta caracterización no parecería encajar demasiado en los rasgos dibujados por Galeas que, por ejemplo, considera a Riqueza hija de Mundo y no aparece privada de la vista. Por ello, transcribo la segunda descripción: «Mujer de regio atuendo, recamado con joyas variadas de valor elevadísimo. Sostendrá con la diestra una Corona Imperial, sujetando además con la siniestra un cetro, y poniéndose ante sus pies un gran cáliz de oro» (Ripa, Iconología, t. II, pp. 276 277, las citas en p. 276). Incluimos las descripciones de las imágenes de estos dos personajes alegóricos, porque, al margen de que se plasmasen así sobre la escena, es plausible que estuvieran en el imaginario de Galeas, igual que en el del lector de la época, y, al mismo tiempo ofrecen a los lectores de hoy día la posibilidad de visualizar una caracterización de dichos personajes de los que estamos tan alejados.

63. allego: 'llego'. 
MUNDO.- Riqueza, mi hija amada, tu buen comedimiento y el ser agradescida a mis regalos me convida a que de nuevo te ame y de nuevo te regale. Pide tú lo que quisieres, que, pues soy tu padre que tan tiernamente te ama, ¿qué puedes tú pedir que yo no haga y qué haré por ti que no lo deba?

RIQUEZA.- ¡Oh Mundo, y qué de veras te muestras para mí amoroso padre!, pues, lo que la vergüenza acobardaba y me impedía, tu liberalidad lo allana y me esfuerza. Mi señor, dame las manos, besarlas he de rodillas ${ }^{64}$.

Mundo.- Levanta, hijo65, levanta, y da lugar a que en algo se conozca que como padre te amo, porque, según tu crianza y tus graciosas palabras, en darte lo que pidieres más será pagarte deuda por lo que meresces que hacerte gracia por el amor que te tengo.

RiqueZA.- Padre mío, has de saber que este día viene a aposentarse en ti el más alto y más poderoso señor que tiene la tierra y, como a tal, con favor tuyo, yo querría aparejarle la más alta y la más rica posada que en ti se hallase para que en ella, como en cosa tan señalada, mostrare yo la majestad de mi grandeza, y la prosperidad y la abundancia de mis bienes.

MUNDO.- Por cierto, hijo, lo que pides es tan justo y tan proprio de mi condición que sobre ello hay poca nescessidad de rogarme, pero ¿dime dónde viene a aposentarse aquese grande señor?

RıQUEZA.- A Belem viene esta noche.

MUNDO.- ¿A Belem? Pobre y pequeño es el pueblo.

RıQUEZA.- Pues ahí quiero yo mostrar mi grandeza y el favor que contigo tengo.

Mundo.- Riqueza, ya yo te he dicho que de mi parte no habrá falta, pero temo que quien tal pueblo escogió para su venida, siendo él tan grande y tan alto, que 66 terná en muy poco tu rica posada y no vaca ${ }^{67}$ de misterio lo que digo.

RIQUEZA.- ¿Cómo assí?

Mundo.- Porque he entendido que esta noche la Pobreza rescibe en ese lugar al más soberano huésped de la tierra, de que no estoy poco admirado, porque ni tiene cuenta conmigo ni sobre ello me ha hablado.

RiqueZA.- iTriste de mí!, que eso mismo me trae congojado, porque me han certificado que de la venida deste señor ha muchos años que la Pobreza ha sido avisada y, como yo, siendo quien soy, no he tenido tal aviso, lo que por una parte

64. En las tres primeras intervenciones de la obra, el autor nos proporciona la identidad de los personajes (facilita la capacidad de descodificación por parte del público de los personajes alegóricos) y la relación paterno-filial entre ambos: este recurso es recurrente en las obras aquí editadas.

65. Mundo en su intervención anterior ha llamado a Riqueza «mi hija amada», ahora, por dos veces consecutivas, se dirige a ella en masculino, y Riqueza se referirá a sí mismo en masculino: congojado. En nota anterior, aludíamos a la posibilidad de que los personajes alegóricos pudieran ser masculinos o femeninos, con independencia del género gramatical de su denominación; no obstante, resulta extraño que en una misma pieza en tan corto espacio de escritura y de dicción un mismo personaje, como ocurre aquí con Riqueza, unas veces sea masculino y otras inmediatas femenino. Nos preguntamos, si esta vacilación fuera debida a un lapsus del copista o del autor.

66. que: esta repetición del que, después de algún término o frase, era práctica común en el siglo XVI, cuando algún elemento de la oración se situaba entre que y el verbo de la misma (Keniston, 1937, p. 675). 67. vaca: 'carece' 
me hace temer, por otra, me hace dubdar. La dubda fue causa de no revelarte al principio mi pena, y el temor hace agora declararme contigo para que tú como padre me aconsejes en todo lo que debo.

MUNDO.- Entiende, Riqueza, que este negocio es muy importante y depende dél solo no tu aucthoridad, mas la mía; y en él me paresce que hagas dos cosas: la una será que adereces con diligencia un rico y grande aposento para este señor, que no puede ser, si no es más que hombre, que en tu posada hospedarse no quiera por hospedarse con cosa tan baja como es la Pobreza.

RIQueZA.- ¿Y qué es la otra cosa que debo hacer?

MUNDO.- Que en brevedad procures de verte con la Pobreza y entiendas el hecho muy de raíz ${ }^{68}$

RIQUEZA.- Como lo entiendes, lo entiendo hacer y aun pienso llevar en mi compañía a dos mis criados: Solicitud y Curiosidad.

MUnDO.- Muy bien has dicho. ¡Suso!, camina.

RIQUEZA.- ¡Anda, señor, y yo seguirte he!

MUNDO.- ¡Sea muy en buen hora! Vamos los dos y cantando por mi amor.

Con el regalo, señor

que siempre me sueles dar alegre puedo cantar.

Segunda parte en que se introducen la Pobreza, y Simplicidad y Sosiego, sus hijos, y entran cantando ${ }^{69}$.

Cantemos con regocijo,

pues de bienaventuranza

se nos da grande esperanza.

68. de raíz: «modo adverbial, que vale enteramente, u desde el principio hasta el fin de alguna cosa» (Aut.). 69. Pobreza y Simplicidad: sobre su posible caracterización escénica, Cesare Ripa ofrece varias descripciones de la Pobreza: «mujer vestida al modo de las gitanas», «mujer desnuda y macilenta», «mujer pálida, furiosa y vestida de negro», etc... (Iconología, t. II, pp. 216-218); sin embargo, a mi parecer, el personaje creado por Galeas estaría más cercano al concepto de la Pobreza de Espíritu, la primera de las bienaventuranzas. He aquí parte de la descripción que hace Cesare Ripa: «Se representa en la figura de una muchacha que lleva el traje corto y desgarrado. [...]. Es doncella por ser las de su sexo más dadas a la religión y más exentas de altivez de ánimo que el sexo masculino [...] Aparece con vestido corto, indicando así sus pocas pretensiones en cuanto a las cosas del mundo; pues el traje largo siempre fue símbolo de dignidad y preminencia sobre los otros. [...] El traje desgarrado [...] indica la humildad, que es lo propio de la pobreza de espíritu [...]» (Iconología, t. I, p. 149). Es verdad que esta imagen no se ajusta en su totalidad al personaje de la obra, pues Pobreza no es doncella, tiene dos hijos, pero la descripción del vestuario sí podría encajar (más aún por oposición a la de Riqueza) y también su carácter: la humildad. En Ripa, la Simplicidad se dibuja como una «Jovencita vestida de blanco, que llevará entre las manos un Faisán junto a una blanca Paloma. [...] Viste de blanco por cuanto dicho color es simple por completo, es decir, que carece en absoluto de composición» (Iconología, t. II, p. 316.). En Galeas, Simplicidad es un personaje masculino, sí podría ser joven puesto que es hijo de Pobreza y podría ir de blanco. 
PobrezA.- Hijos míos, el alegría que regocija mi alma es tan grande que ya, ya, ya no puedo contenerme ni dejar de publicarla, porque el mesmo regocijo que siento acá en las entrañas, por salir de la raíz de do sale, cresce ya tan sin medida que en un pecho tan pequeño como el mío ya no cabe, y así yo, tan forzada de aquesta estraña grandeza de alegría, os he querido llamar para daros parte della.

SosIEGo.- ¡Sancto Dios!, ¿qué puede ser? ¿Qué novedad es esta? ¿Quién desteró tus sospiros? ¿Tus gemidos dónde están? Di, Pobreza, madre mía.

\section{Cantan los dos hermanos. \\ ¿Dónde está la que gemía, madre mía? \\ ¿Dónde está la que gemía, la que lágrimas vertía, madre mía? \\ ¿Cómo está con alegría?}

SIMPLICIDAD.- Decid, madre, ¿que es possible que ha llegado a vuestra casa regocijo?

PoBrezA.- Sí, sí, hijo.

SIMPLEZA.- ¿Y que puedo yo bailar, danzar y zapatear a discreción?

POBREZA.- Con discreción.

SIMPLEZA.- ¿Que, si yo os pido un regalo, me dirás, como soléis: «iNo lo hay!»?

POBREZA.- Ya lo hay.

SIMPLICIDAD.- ¡Bendito sea el señor que lo dio!

SosiEgo.- [Aparte.] (Hermano Simplicidad, mira y siente que, en hecho tan admirable como entre manos tenemos, no te debes contentar con solo lo que entendiste de Pobreza, nuestra madre.

SIMPLICIDAD.- Di, Sosiego, hermano mío, tú que con reposo hablas muy pensado y muy pausado, ¿hay alguna cosa más que entender o preguntar?

SOSIEGO.- Grandes cosas y de muy grande importancia.

SimPLICIDAD.- Esas yo no las alcanzo. Tú, Sosiego, las pregunta, que las entiendes y sabes.)

SosiEgo.- Di, Pobreza, madre nuestra, aqueste tu regocijo, este contento y placer que publicas ¿dónde tuvo principio?

SIMPLICIDAD.- [Aparte.] (¡Oh qué donosa pregunta! ¡Qué a propósito y qué buena por cierto! Yo no atinara en los días de mi vida con pregunta semejante.)

PobrezA.- Pues, oídme, hijos míos, y veréis cuán justa es la causa de mi alegría.

SOSIEGO.- Di, señora.

PobreZA.- Sabed, mis hijos amados, que el Príncipe soberano, hijo del eterno Padre, Dios de Dios y Señor nuestro, de su corte celestial ha venido a la del suelo y con divino consejo ordenó de aposentarse - ¿a dó pensáis? - en la posada - ¿direlo?- de mí, la humilde Pobreza.

¡Qué grande bondad, qué suma grandeza, 


\section{que quiera posar}

el rico en pobreza!

SOSIEGO.- ¿Para qué vino a la tierra aqueste grande Señor?

PoBREZA.- ¿Para qué? Para enriquescer a los pobres, engrandescer los humildes y dar la vida por sus enemigos. ¡Mirad si hay grande razón de alegrarnos!

SIMPLICIDAD.- Madre mía, ¿esta alegría es solo para nosotros o es bien universal para el mundo?

POBREZA.- Para el mundo.

SIMPLICIDAD.- ¿De modo que ha de ser limpio, mundo ${ }^{70}$ y puro el que quisiere gozar de este remedio?

POBREZA.- Ese es el medio.

SIMPLICIDAD.- ¿Y el que hobiere sido malo, y detestare el peccado y hiciere penitencia gozará de aqueste bien?

POBREZA.- Ese también

SIMPLICIDAD.- Luego, yo bien gozaré si soy limpio y si trabajo.

PoBREZA.- $Y$ aún con trabajo.

SIMPLICIDAD.- Y por no ser tal el hombre, dime, ¿qué se perderá?

PoBREZA.- Que se perderá71.

SIMPLICIDAD.- ¡Líbrame, Señor, amén, de perder tan grande bien! Madre mía, yo quiero que me respondas a otra sola pregunta.

PoBREZA.- Pregunta.

SIMPLICIDAD.- ¿Por qué quiso así venir este señor? Dilo agora por mi amor.

PoBREZA.- Por tu amor.

\section{Cantan}

¡Seáis bien venido, Señor,

por nuestro amor!

¡Seáis bien venido, Señor!

PoBrezA.- Hijos míos, vamos presto a la posada, que yo quiero aderezar el hatico pobrecillo que tenemos para poder rescebir este divino huésped que esperamos, que ya se acerca la hora de su dichosa venida.

SIMPLICIDAD.- ¡Vamos mucho en buena hora y no se olvide el cantar!

SosIEGo.- Comienza, Simplicidad, que todos te ayudaremos.

SIMPLICIDAD.- ¡Soy contento, por mi vida!

70. mundo: cultismo léxico, procedente del adjetivo latino mundus- a - um, con el significado de 'limpio, arreglado', que tiene como opuesto el adjetivo immundus, inmundo: 'lleno de basura o suciedad, indecente, impuro'.

71. Es destacable el juego de palabras que está presente a lo largo de toda de esta Segunda parte y que tiñe de comedia la escena: a discreción / Con discreción; y si trabajo / Y aún con trabajo; ¿qué se perderá? / Que se perderá. 


\title{
Cantan.
}

¡Alégrate, mi alma, que es venida tu gloria, tu paz, tu lumbre y tu vida!

\author{
Tercera lición ${ }^{72}$, en que se introducen Solicitud ${ }^{73}$, y Curiosidad ${ }^{74}$ y Riqueza, \\ y dos Truhanes.
}

SolicITUD.- ¡Anda más, Curiosidad! ¡Anda, si quieres, que es tarde!

CURIOSIDAD.- Espera, Solicitud, espera, que tengo de ver dó pongo los pies, porque esta subida ${ }^{75}$ no está nada buena. Y, si por aquí la Riqueza ha entrado, muy justo sería que se aderezase con otro cuidado, otra limpieza y más policía ${ }^{76}$.

SolicituD.- ¡Oh, Curiosidad, y qué terrible cosa es oírte y qué pesada sufrirte! Dime agora ¿qué es la descomposición que en esta subida hallas?

CURIOSIDAD.- Harto grande.

SOLICITUD.- ¿Y cuál es?

72. lición: 'lección'. Lecciones: «Se llaman entre los Eclesiásticos, las tres o nueve leyendas del Breviario, que en los maitines se rezan o cantan, que son de Escritura, Vidas de Santos y Exposición del Evangelio» (Aut.). Es decir, se trata de un término de uso litúrgico. Este empleo por Galeas induce a pensar en la posibilidad de que esta segmentación en Partes fuera debida, si esas piezas llegaron a representarse, a que dichas Partes fueran intercaladas entre los intervalos temporales del rezo o canto de las horas canónicas. 73. Solicitud: caracterizada por Cesare Ripa como «Mujer vestida de rojo y verde que coge con la diestra una espuela o aguijón sujetando una antorcha con la izquierda. El traje rojo y verde simboliza el mezclar la esperanza con el amor o el deseo, engendrándose de ambos la presente solicitud. El aguijón significa por su parte el eficaz deseo de conseguir o rematar alguna cosa [...]. Con la indicada antorcha también se muestra el deseo y encendida solicitud que, ardiendo y abrasando nuestro corazón, no consiente que vivamos con paz y tranquilidad si no se alcanza el buen fin de nuestro intento» (Iconología, t. II, p. 316). La utilización de la antorcha por parte de Solicitud podría dar mucho juego escénico, más aún en un inicio de escena donde se está ascendiendo por un camino y más todavía si la pieza se representó, o al menos para ello estaba compuesta, en la penumbra de una iglesia o capilla durante el rezo o canto de las horas canónicas, como sugeríamos en nota anterior.

74. Curiosidad: Ripa la describe como «Mujer vestida de azul y rojo, sobre cuyo traje se verán diseminadas muchas ranas y orejas. Llevará tieso el cabello y las manos en alto, sacando hacia afuera la cabeza y con alas a la espalda. La curiosidad consiste en un deseo desenfrenado que posee a los que tratan de saber más de lo que deben. Las orejas significan que el curioso no tiene otro deseo que el oír y saber las cosas que los otros dicen. [...] Las ranas, que tienen los ojos muy grandes, son símbolo de la curiosidad [...]. Lleva altas las manos y adelantada la cabeza, porque el curioso siempre está atento y vivaz para saber y extender las novedades, vengan de donde vengan. Lo mismo significan las alas y los cabellos tiesos, representándose con ellos la vivacidad de pensamiento. En cuanto a los colores del vestido, significan el ansia de saber (Iconología, t. I, p. 248). En pocas ocasiones, nos podemos encontrar con una descripción de un vestuario más teatral que esta.

75. porque esta subida: ¿Qué supondría esta subida escénicamente en la puesta en escena? ¿Existiría una altura a la que condujeran unos escalones, a los que se alude después por Curiosidad con motivo de su inapreciable o mínima diferencia de sus respectivas alturas? También sería posible que los actores mimaran la acción, lo que redundaría en la comicidad de la escena.

76. policía: «aseo, limpieza, curiosidad y pulidez» (Aut.). 
CURIOSIDAD.- Que el primero paso ${ }^{77}$ della es más alto que el segundo casi, casi una pulgada ${ }^{78}$.

SOLICITUD.- ¿Esa toda es la falta que tiene?

CURIOSIDAD.- También tiene otras.

SOLICITUD.- Dime cuáles.

CURIOSIDAD.- Que al pie de aquesta subida están dos plumas de un ave. ¡Mirad qué gentil limpieza!

SoliciTUD.- ¡Oh, gran Dios, quién se hallase mill leguas de ti apartado, do no te oyese ni viese! (¿No veis de qué miserias hace caso Curiosidad?) [Aparte.]

CURIOSIDAD.- Solicitud, ¿y pensaste tú que por tus prissas desordenadas se ha de mudar mi condición? Pues entiende que yo no soy quien tú eres.

SOLICITUD.- ¿Ya sabes tú quien yo soy?

CURIOSIDAD.- ¡Y cómo que lo sé bien y de qué casta vienes!

SOLICITUD.- ¿Conociste tú a mis padres?

CURIOSIDAD.- Conoscilos.

SOLICITUD.- ¿Quiénes fueron?

CURIOSIDAD.- Tu padre el proprio Interesse y tu madre la Cobdicia, gente infame y desalmada.

SolicITUD.- Bien muestras que tú eres Curiosidad y que te sobra tiempo para saber linajes y vidas ajenas, pero, dime, ¿sabes tú de dónde vienes?

CURIOSIDAD.- ¿Por qué lo dices?

SolicitUD.- Porque es cosa dificultosa cognoscerse el hombre a sí mismo y sospecho que, aunque tú sabes muy bien quién fueron mis padres, no debes saber quién fueron los tuyos.

CuRIOSIDAD.- Por cierto, sí sé.

SOLICITUD.- ¿Quiénes son?

CURIOSIDAD.- Mi padre es el Ocio.

SOLICITUD.- ¿Y tu madre?

CURIOSIDAD.- Haraganía 79 .

SolicITUD.- ¡Oh que gente tan honrada! ¡Por cierto, tú vienes de muy gentil casta! Di, Curiosidad, ¿no entiendes y vees que por affrentarme te has affrentado? De aquí podrías tú sacar en limpio que a todos conviene que honre el que de todos quiere ser honrado y que no puede caer en corazón generoso quererse honrar con afrentas ajenas.

CURIOSIDAD.- No pases adelante, Solicitud, que paresce que viene Riqueza, nuestra ama.

SOLICITUD.- ¡Venga mucho en buena hora!

CURIOSIDAD.- Señora, dadme la mano.

RIQUEZA.- ¡Dejadme, que yo subiré!

77. paso: 'escalón'.

78. pulgada: «medida que es la duodécima parte de un pie y equivale a algo más de 23 mm» (DRAE).

79. Haraganía: «Lo mismo que haraganería: «flojedad, pereza y falta de aplicación» (Aut.). 
SolıCITUD.- Dime, señora, ¿por qué nos mandaste a Curiosidad y a mí esperarte en este lugar? ¿Qué es lo que mandas?

RIQueZA.- Entiende, Solicitud, y tú, Curiosidad, advierte que hoy se me offresce un negocio el más arduo que en la vida he tenido y, puesto que siempre os he hallado fieles en las cosas de mi servicio, en aquesta quiero yo que los dos os señaléis, magnificando la grandeza de mi imperio y la prosperidad de mis bienes.

CURIOSIDAD.- Mi señora, manda tú a Solicitud que me deje a mí hacer y no me vaya a la mano ${ }^{80}$, que yo magnificaré el aucthoridad tuya, de suerte que en los siglos venideros se haga perpetua memoria de ti.

Solicitud.- Mira, Curiosidad, no pienses por esa vía aventajarte conmigo delante de mi señora, porque, si tú quieres mucho servirla, yo deseo más agradarla, que en lo que yo te voy a la mano no es cosa de su servicio, sino en grandes demasías de tu inconsiderada imaginación que son fuera de todo propósito.

RIQUEZA.- Por mi vida, Solicitud, que no rescibas fastidio de lo que Curiosidad quisiere que se provea, que yo rescibo a mi cuenta este servicio para lo gratificar mucho bien.

SolıcITUD.- Di, señora, lo que quisieres, que por servirte me esforzaré a hacer lo que mandas.

CURIOSIDAD.- (iOh, traidor, cómo finges esforzarte por servicio de mi señora y no te esfuerzas sino porque te asegura que estarán de por medio tus padres, Interesse y Cobdicia!

SOLICITUD.- ¿Qué es lo que dices, Curiosidad?

CURIOSIDAD.- Bien me entendiste. No digo nada.) [Aparte.]

SOLICITUD.- Di lo que mandas, señora.

RIQueZA.- Lo que quiero es que con todo el primor y policía possible se aderesce en mi posada un principal aposento, porque espero en él por huésped al príncipe más poderoso de la tierra y, conforme a su grandeza, querría manifestarle los thesoros de mi valor.

Solicitud.- Pues, isuso!, señora. Diga Curiosidad lo que se ha de proveer, y porné faldas en cinta ${ }^{81}$ y proveeré con brevedad cuanto fuere menester.

RIQUEZA.- Comienza, Curiosidad.

CURIOSIDAD.- Digo que, ante todas cosas, la sala alta principal de mi señora se ha de limpiar de suerte que de sola la limpieza resplandezca, y en ella se colgarán unos doseles medianos de tela de oro guarnescidos de otra tela de oro y plata, y en el lugar principal desta sala habrá un dossel de brocado de tres altos y, en medio dél, se pornán dentro de un rico cestón de su oro matizado las armas de nuestro huésped, y, advierte, Solicitud, que a nivel, regla y compás se dé por toda la sala una línea por donde sean clavados los doseles para que vayan iguales sin discrepar un cabello.

SolicITUD.- ¡Qué por menudo tractas las cosas, Curiosidad! ¿Regla, nivel y compás ha de haber para colgar seis doseles?

CURIOSIDAD.- Así conviene.

SolICITUD.- Di. iAdelante!

80. y no me vaya a la mano: 'resista', 'contradiga'.

81. porné faldas en cinta, poner faldas en cinta: «determinarse a hacer una cosa con mucha diligencia» (Cov.). 
CURIOSIDAD.- El techo de aquesta sala será un cielo, por tal orden fabricado que el sol esté en él de día corriendo todo su curso desde el oriente al poniente, y de noche salga en él la luna con las estrellas que hagan sus movimientos por el orden natural que aquestos cielos lo hacen.

SOLICITUD.- ¿Estás burlando, Curiosidad?

CURIOSIDAD.- No, por cierto.

Solicitud.- Pues, veamos. ¿Este cielo es cosa de encantamento o de arte de nigromancia?

CURIOSIDAD.- Es arte de policía y de ingenios delicados y curiosos.

RIQUEZA.- Curiosidad, date priesa, que se va haciendo tarde.

CURIOSIDAD.- En el testero más largo de esta sala, habrá un reloj mediano que dé sus horas a tiempo y, cerca de él por lo alto, una figura de hombre de metal con una buena ballesta, y gafas y un pasador ${ }^{82}$ en las manos, y para subir a ella ha de haber cuatro escalones muy estrechos, por tal ingenio labrados que, puesto el pie en el primero, arme luego la ballesta y, en el segundo, encaje su pasador y, puesto el pie en el tercero, aseste contra el que sube y, si subiere en el cuarto, desarme con toda furia. Terná sobre la cabeza esta figura un hermoso vaso de oro con una «letra» ${ }^{83}$ que diga:

Este es un vaso precioso

y, si queréis gozar de él, subid sin temor por él.

SolicITUD.- ¿No sabes qué estoy pensando, Curiosidad?

CURIOSIDAD.- Dime qué.

SolicITUD.- Que es un sueño cuanto dices.

CURIOSIDAD.- No es sino cosa real y muy cierta, y es una prueba graciosa para hombres animosos.

RIQUEZA.- Di adelante. No pares.

CURIOSIDAD.- En medio de aquesta sala, habrá una poma ${ }^{84}$ grande de cristal en círculo bien sacada, que parezca que depende ${ }^{85}$ desde el cielo, y dentro de ella pornás a seis niños desnudicos que estén danzando y bailando alderredor con lumbres, las que convengan para que se puedan ver.

Solicitud.- Mi señora, ya esto no es de sufrir. Si por esta vía va, lo que más es menester será un nunca acabar.

CuRIOSIDAD.- Pues entiende, Solicitud, que lo essencial y lo bueno que se ha de proveer no está tocado, ni he tractado de fuentes de diversos licores, de aves vivas en los manjares, de la policía en los servicios, ni de comedias, disfraces, sa-

82. pasador: «cierto género de flecha, o saeta muy aguda, que se dispara con ballesta» (Aut.)

83. letra: «mote que explica el cuerpo de una empresa» (Aut.)

84. poma: 'vasija'

85. depende, depender: 'colgar o pender' (DRAE).

HIPOGRIFO, 9.1, 2021 (pp. 1187-1266) 
raos, blandones ${ }^{86}$, sitiales ${ }^{87}$ y vajillas, ni otros mill cuentos de cosas nescesarias e importantes.

RIQueZA.- Ora ${ }^{88}$, jsus!, Curiosidad, por mi amor, que por scripto ${ }^{89}$ me des todo lo que falta.

CURIOSIDAD.- Soy contento, pero una sola cosa conviene que aquí veamos.

SOLICITUD.- ¿Y cuál es?

CURIOSIDAD.- Dos truhanes ${ }^{90}$ que salgan a rescebir nuestro huésped y regocijen la fiesta con mill gracias y donaires.

SoliciTUD.- Yo cognosco dos rapaces cabales en el officio.

RIQUEZA.- Pues procura de traellos brevemente.

SOLICITUD.- Al puncto vernán aquí.

RIQueZA.- Curiosidad, bien entiendes que depende deste hecho todo el ser y auctoridad de mi grandeza, por tanto, mira muy bien no haya falta ni descuido.

CURIOSIDAD.- Pierde cuidado, señora, y asegúrate de mí, pues yo lo tomo a mi cargo.

\title{
Entran los Truhanes con la Solicitud cantando con sonajas y guitarra.
}

\author{
¡Viva, viva, viva, \\ viva la Riqueza! \\ ¡Viva, viva, viva, \\ viva su grandeza! \\ Copla \\ ¡Viva la Riqueza \\ y sus servidores; \\ no teman Pobreza
}

86. blandones, blandón: «hacha de cera para alumbrar. [...] Por metonimia se entiende aquel hachero o candelero grande en que ordinariamente se ponen las hachas o blandones de cera» (Aut.).

87. sitiales, sitial: «el asiento o silla con un pequeño banco delante, cubierto de un tapete con una almohada, o cojín encima, y otra a los pies de la silla, de que usan los reyes, príncipes y prelados en la asistencia de las funciones públicas» (Aut.).

88. Ora: «adv. Lo mismo que ya» (Aut.).

89. scripto: 'escrito'.

90. Truhanes, truhan: «el que con acciones y palabras placenteras y burlescas entiende en divertir y causar risa en los circunstantes» (Aut.). La figura del truhan no era ajena en el teatro religioso del tercer cuarto del Quinientos. Así lo encontramos como personaje dramático en dos piezas del Códice de Autos Viejos: XVI. Aucto del rey Asuero quando desconpuso a Basti, y XXVII. Auto de Sanct Christobal (en Colección de autos, farsas y coloquios..., ed. 1901, t. I, pp. 267-282 y 411-467, respectivamente), con mayor desarrollo como tal en el primero que en el segundo. En ambos, su actuación es conforme a los moldes prefijados de esta figura, pero en ninguno de ellos alcanza la detallada caracterización de sus múltiples y agudos "comportamientos y habilidades" que conformaban su manera de vivir, como en uno de los dos truhanes de Galeas. Ello no debe extrañarnos, pues este fraile cartujo que, al parecer, había ejercido un cargo en la Audiencia de Sevilla, debía conocer bien este tipo de personajes pululantes, como otros muchos, en ese inframundo de marginación coexistente con el mundo de riqueza y prosperidad que gozaba la acaudalada y cosmopolita Sevilla del Quinientos, cruz y cara de una misma moneda. 


\title{
y sus disfavores! \\ ¡Grandes y menores \\ sigan la Riqueza! \\ ¡Viva, viva, viva, \\ viva su grandeza!
}

TRUHAN.- Beso las manos a V. M. muchas veces, mi señora.

RIQUEZA.- Seáis bien venido, amigo.

\author{
Cantan los Truhanes. \\ ¡Seáis bien venido, amigo! \\ ¡Vos seáis bien venido! \\ ¡Vengáis mucho en buena hora \\ a servir a esta señora, \\ porque en ella se athesora \\ el thesoro no abscondido! \\ ¡Vos seáis bien venido!
}

CURIOSIDAD.- De repente paresce que trova.

TRUHAN.- Sí, señor. De repente trovo, aúllo como lobo, canto como gallo, ladro como perro y corro como gamo. Esgrimo, salto, danzo y bailo. Hago del ciego, del sordo, del mudo y tartamudo, y del ventero. Hago del gitano, juego a la corregüela ${ }^{91}$, sé jugar de mano ${ }^{92}$ y al juego de pasa pasa ${ }^{93}$. Hablo portugués, francés, viscaíno ${ }^{94}$, flamenco y ginovés. Taño vihuela, laúd, flauta, guitarra, chirimía, sonajas y rabelico 95

RıQueZA.- Por cierto que es harto hábil el rapaz en el oficio.

91. corregüela: «juego con el que se divierten los muchachos, el cual hacen con una corregüela ['correa'] de un dedo de ancho, y poco más de vara de largo, con la cual forman diferentes dobleces y vueltas, y luego con un palillo o puntero le meten en uno de los dobleces a discreción: y, si el palillo o puntero queda encerrado, u dentro de la corregüela, gana el que puso el puntero, y, si queda fuera de la corregüela gana el que la tiene (Aut.). 92. jugar de mano, jugar de manos: «loc. verb. coloq. [...] Retozar o enredar, dándose golpes con las manos» / juego de manos: «truco de prestidigitación» (DRAE).

93. juego de pasa pasa, también llamado juego de masecoral o maesecoral y de masegicomar: «todos estos nombres tiene el embaidor que nos hace, como dicen, del cielo cebolla, por la liberalidad que tiene en trocar las cosas, y así el juego se dice también juego de manos. Y entre otros traen el de los cubiletes, adonde meten ciertas pelotillas, que a nuestro parecer quedan dentro, y al asentar el cubilete las saca y las pone en otro que nos muestra ponerle cerca dél vacío, y con un palillo da ciertos golpes y dice ciertas palabras repitiendo el pasa pasa, de donde tomó nombre el juego; y alzando muy despacio el cubilete, no se halla nada en él. Da otros golpecitos al otro cubilete y halla las pelotitas todas en él; toma luego tres cubiletes y pone a nuestro parecer en cada uno la suya, y después derrúecalos todos con la vara y están vacíos; torna a ponellos y hállalas todas tres en el cubilete y volviendo a dejallas todas tres dentro, las halla después las tres repartidas cada una en su cubilete» (Cov., s. v. juego). Sobre la historia del juego del maesecoral y de sus amplísimas referencias en nuestra literatura, véase Perea Rodríguez, 2010.

94. viscaíno: caso de seseo.

95. rabelico: diminutivo de rabel, «instrumento músico pastoril. Es pequeño, de hechura como la del laúd. Compónese de tres cuerdas solas, que se tocan con arco, y forman un sonido muy alto y agudo» (Aut.). 
TRUHAN.- Tengo mill cuentos de gracias, de chistes y de donaires. Contrahago y hago gestos. Sé baratar ${ }^{96}$, y enlabiar ${ }^{97}$ y hacer con behetría ${ }^{98}$ trampantojos $^{99}$. En locura, yo puedo dar quince y falta ${ }^{100}$ a cuantos hoy son nascidos. ¿Queréis ver a dó llega mi saber? Sé ${ }^{101}$ servir sin gana y llorar sin gana y comer sin gana, y soy en aqueste officio como conde palatino ${ }^{102}$ que doy grados ${ }^{103}$ al nescio de discreto, al ignorante de sabio, al feo de hermoso y al cobarde de valiente ${ }^{104}$.

RıQUEZA.- ¿Es también el compañero assí gracioso?

TRUHAN.- Es muy donoso, pero quiso su ventura que, demás de cuatro effes, frío, flojo, flaco y feo, tuviese otras cuatro letras.

CURIOSIDAD.- ¿Cuáles son?

TRUHAN.- Ceceoso, tartajoso, sarnoso y segajoso ${ }^{105}$. Verdad que sabe algo de danzar y de bailar, y de gomecillo de ciego ${ }^{106}$ hace un poco y de monacillo de choro ${ }^{107}$ otro poco

RIQUEZA.- Ora pues, tánganles ${ }^{108}$ algo y veremos cómo bailan.

Aquí les tañen a los Truhanes y bailan un villancico.

RıQueZA.- Por cierto, lo hacen bien. Entremos a la posada, que en tanto que se adereza me tengo de ir a ver con la Pobreza.

SOLICITUD.- ¡Vamos mucho en buena hora!

\section{Salen cantando los Truhanes.}

Pues de mí, señora, queréis ser servida ${ }^{109}$,

96. baratar: «trocar unas cosas por otras» (Aut.)

97. enlabiar: «atraer, alucinar, tener suspenso, y en cierto modo engañado a alguno, con la elocuencia y energía de las palabras y discursos» (Aut.).

98. behetría: «tropel, barullo y alboroto» (Martín Alonso).

99. trampantojos: «la trampa y engaño que alguno nos hace en nuestra presencia y delante de nuestros ojos» (Cov.).

100. dar quince y falta: «superar en mucho» (Martín Alonso, s. v. quince).

101. Sé: en el ms. que (fol. 125v)

102. conde palatino: «se llaman condes palatinos en Roma ciertos cortesanos que tienen privilegio de poder legitimar naturales, espurios, hacer notarios y licenciados, doctores y otras cosas, las cuales hoy día están reformadas» (Cov., s. v. conde).

103. grados: «en materia de letras los que dan las universidades y colegios privilegiados de bachiller, licenciado y doctor» (Cov.).

104. como [...] valiente: comparación muy semejante en Mateo Alemán, Primera parte de Guzmán de Alfarache (Madrid, 1599): «graduando, como conde palatino, al necio de sabio, al feo de hermoso y al cobarde de valiente» (Parte I, Libro I, Capítulo Primero, p. 33, ed. Gómez Canseco), lo que sitúa al autor en la construcción de este personaje dentro de la tradición literaria de la picaresca.

105. segajoso, cegajoso «corto de vista y casi ciego» (Aut.), con evidente seseo.

106. gomecillo de ciego: «lo mismo que lazarillo de ciego» (Aut.).

107. monacillo de choro: «El niño que sirve en los Monasterios y Iglesias, para ayudar a Misa y otros ministerios del Altar» (Aut.).

108. tángales: 'táñanles', procedente del verbo latino tangere.

109. Verso hipométrico y sin sentido en el ms. - quereis seruida (fol. 126r) -, corregido por necesidades métricas y de sentido. 


\title{
por vuestro servicio \\ daré yo la vida.
}

Cuarta parte en que entra Pobreza con Sosiego y Simplicidad, sus hijos, cantando y adelante entra la Riqueza.

\author{
La media noche obscura \\ paresce al mediodía, \\ pues nace en ella el sol, \\ la luz y el alegría.
}

PoBREZA.- Hijos míos, la hora se acerca ya de aquella buena venida que esperamos. No paresce sino que el cielo, regocijado de nuestro bien, apresura sus movimientos para pedirnos albricias y que este, mi corazón, con unas voces secretas de alegría, responde al cielo diciendo: «Amigo, yo te las mando».

SIMPLICIDAD.- Decid, madre, ¿a una cosa tan alta como el cielo qué albricias podría dar una tan pobre mujer como vos?

PoBREZA.- Darle ya el amor y el desseo de darle, que es la cosa más preciosa que yo tengo y, para el cielo, esso que paresce poco es de muy grande valor.

SosıEGo.- ¡Silencio, silencio!, que viene gente de fuera.

RıQueZA.- Hermana mía, Pobreza, estés mucho en buena hora.

PoBREZA.- ¡Muy bien venida seáis, mi señora! ¿Qué novedad es aquesta de venir a mi posada?

RIQUEZA.- Vengo, hermana, a visitarte y a regocijarme contigo.

SIMPLICIDAD.- Decid, madre, ¿quién es aquesta mujer que, siendo tan rica, a vos, pobre, hermana os llama?

PobrezA.- Es la Riqueza.

SIMPLICIDAD.- ¿Riqueza por vuestra casa? ¡A fee que os ha menester!

SosIEGo.- (Simplicidad, calla tú. No seas demasiado ${ }^{110}$.

SIMPLICIDAD.- Yo callo, mas tú verás que el entrarse por la puerta es por lo que le conviene. No para hacernos bien.) [Aparte.]

PobreZA.- Di, señora, lo que mandas.

RIQUEZA.- Desseo saber de ti una verdad y ruégote, por mi amor, no me la niegues.

PobrezA.- Por cierto, si yo la sé, la diga muy llanamente.

SIMPLICIDAD.- Mirad, madre, no os engañe.

SosiEgo.- (¡Calla agora! ¡No porfíes!) [Aparte.]

RIQUEZA.- Di, Pobreza, ¿esperas hoy algún huésped que haya de aposentarse en tu posada?

POBREZA.- Espero a todo mi bien con unas alegres ansias de su amor. Por verlo, da mill suspiros mi alma sin darme pena, porque el seguro que tengo de parte de su promesa que ha de venir y he de verle pone en mis ansias dulzura y alegría en mis sospiros.

110. demasiado: «atrevido, desahogado» (Aut.) 
RIQUEZA.- ¿Quién es aquese tu amado que tan estraña mudanza ha hecho en ti? Di ${ }^{111}$, Pobreza.

PoBREZA.- ¿Quién es mi amado preguntas? De los hijos de los hombres, mi amado es el más hermoso. Sus labios son como lirios que están distillando ${ }^{112}$ mirra. Su voz para mis oídos es de muy mayor dulzura que los panales de miel. Sus palabras son tan vivas que me despiertan deseos de vida de eternidad. Todo desiderable 113 , todo amable, todo suave y gracioso escogido de millares. Tal y tan grande es mi amado, este que mi alma espera por huésped y por señor ${ }^{114}$

\section{Cantan los hijos de la Pobreza.}

¡Tal huésped, mi madre, quererle y amarle, servirle y adorarle!

RıQueZA.- Pobreza, ¿no consideras que este tan grande señor no es justo que se aposente en una pobre posada, cual es la que tú ternás?

PobrezA.- Pues esa es otra grandeza de mi amado, que el mesmo que por su ser es de ángeles servido se quiera tanto humillar que se venga a mi posada para servir a los hombres, enseñándonos en esto que quiere en sí consagrar la humildad y la pobreza, porque ${ }^{115}$ los hombres las amen y las extimen en mucho.

RIQUEZA.- ¿Y no será muy mejor que venga con majestad y poder para que sea adorado y temido de los hombres?

PobrezA.- No sabes lo que te dices, Riqueza, porque bastarte debiera saber que el saber de Dios así lo ordena para tenerlo por bueno y acertado, mas, pues tanto desvarías, yo quiero darte un ejemplo porque con él convencida lo acabes bien de entender. Dime, ¿a quién ternías tú por hombre más esforzado: al que pudiese vencer sus enemigos con armas y fortaleza o al hombre que los venciesse sin armas y con flaqueza?

RiqueZA.- Aqueso cosa es muy clara, que sería gran victoria el vencer con la flaqueza y sin armas.

PoBrezA.- Pues esa misma victoria quiere alcanzar mi señor, porque, siendo Él fortaleza con un ánimo inmortal, se ha vestido de flaqueza para derribar con ella la soberanía del poder infernal.

111. Di: en el ms. de (fol. 128v)

112. distillando: 'destilando'.

113. desiderable: «lo digno de ser apetecido y deseado. [...] viene del latino desiderabilis, que significa esto mismo» (Aut.).

114. Bella evocación de Pobreza del huésped que espera, que nos recuerda el pasaje bíblico del Cantar de los cantares, cuando la esposa alaba a su esposo ponderando sus cualidades $(5,10-16)$, coincidiendo casi literalmente en la descripción de sus labios con la segunda mitad del versículo13: «Sus labios son lirios que destilan mirra fluida», así como la literatura mística.

115. porque: 'para que' con valor final.

HIPOGRIFO, 9.1, 2021 (pp. 1187-1266) 


\section{Cantan los hijos de la Pobreza. \\ ¡Afuera, afuera, Satán ${ }^{116}$, que baja y desciende a darte la muerte aquel brazo fuerte del Gran Capitán!}

RIQueZA.- Veamos, ¿no viene Dios a las casas de los ricos como a casa de los pobres? ¿No sabes tú que Abraham, Isac, Jacob y David fueron ricos y no impidió su riqueza aquel conversar con Dios y el dar y tomar con el común y familiar ${ }^{117}$ ?

PobrezA.- Es así, mas entiende bien, Riqueza, que, aunque aquesos fueron ricos, fueron muy grandes amigos de espiritual pobreza y me tenían a mí dentro de su corazón encerrada. Allí tractaban conmigo, se gozaban, consultaban sus negocios y mis consejos tomaban, y también quiero que entiendas que entre los pobres y ricos que son buenos hay no sé qué de ventaja de los pobres a los ricos.

RIQUEZA.- ¿Y cuál es?

PobrezA.- Que la mano delicada del artífice divino, aunque de su parte labra igualmente a rico y pobre, halla al pobre desbastado ${ }^{118}$ y al rico por desbastar.

RıQUEZA.- ¿Cómo assí?

SoSIEGO.- ¿Hanse de acabar hogaño ${ }^{119}$ tus preguntas? Di, Riqueza.

SIMPLICIDAD.- (Déjala, que buena va, por mi fee, que nuestra madre le ha dado entre ceja y ceja ${ }^{120}$.) [Aparte.]

RıQuezA.- Pobreza, queda en buen hora, que yo me voy a esperar al mesmo señor que esperas.

PobreZA.- ¡Vete mucho en buena hora!, que este huésped que yo espero a mi posada verná.

RIQUEZA.- ¡Ora, sus, que verse ha! ${ }^{121}$

116. Verso octosílabo en un conjunto de hexasílabos, que obtendría la medida hexasilábica de los restantes de la composición con la supresión de uno de los dos adverbios afuera. Podríamos preguntarnos si se trataría de un error del copista, pero no nos hemos atrevido a corregirlo, porque dicha reduplicación refuerza su sentido y en los versos cantados no siempre coinciden la métrica literaria con la métrica musical, pues, más allá de la métrica literaria, pueden haber existido en el discurso literario-musical, efectos de síncopa, contratiempo, acentuación extrarrítmica y otros recursos rítmicos. Agradezco al Dr. D. Francisco J. Escobar Borrego estas interesantes indicaciones respecto a la relación entre ambas métricas. 117. el dar y tomar con el común y familiar: 'tratar, discutir, con personas corrientes, ordinarias y familiares', o sea, con personas de más baja condición social. Es decir, la riqueza de estos patriarcas bíblicos no les impidió hablar con Dios y tratar con el común de las gentes.

118. desbastado, desbastar: «limpiar los corazones, desterrando de ellos los defectos o pasiones humanas, para que en su lugar se puedan introducir las virtudes y perfección de vida» (Aut.).

119. hogaño: 'este año'.

120. le ha dado entre ceja y ceja, dar entre ceja y ceja: «frase que significa decir a uno en su cara alguna cosa que le sea muy sensible» (Oliveres, 1841).

121. Exhortación de Riqueza al marcharse del lado de Pobreza, con el sentido de '¡Vamos, que ya se verá!', es decir, dudando de la afirmación categórica de Pobreza. 


\section{Sale la Riqueza.}

SIMPLICIDAD.- ¡Vaya, vaya, váyase ya la señora, que algo corridilla ${ }^{122}$ va!

PoBREZA.- ¡Suso!, hijos, comenzad a abrir los ojos para ver mi «Desseado» y quedará vuestra vista con una lumbre más bella que la luz y claridad de la estrella; dilatad el corazón y abrid las puertas del alma, porque entre el resplandor del sol divino por ella y con sus rayos encienda un amor de eterno amor, de gloria y de paz en ella. ¡Cantemos con regocijo, con suspiros suppliquemos se quiera manifestar a sus pobres criaturas el mesmo que las crió y viene a morir por ellas!

\section{Aquí la Pobreza con sus dos hijos se hincan de rodillas y dicen cantando.}

Veni, Domine, et noli tardare.

Ostende faciem tuam, et salvi erimus ${ }^{123}$.

122. corridilla: 'avergonzadilla, confundidilla'.

123. «Veni, Domine, et noli tardare. / Ostende faciem tuam, et salvi erimus ("Venid, Señor, y no tardéis. / Muestra tu cara y seremos salvados")»: la primera parte del canto es un verso de un motete de Adviento en la liturgia católica, y la segunda pertenece a Sal, 79, 4, 8 y 20. Precisamente, con este título, Domine, et noli tardare, Cristóbal de Morales (1500?-1553), compone un motete a seis voces (Stevenson, 1993, p. 359), en el que se hallan los dos versos citados por Galeas, con la única diferencia de que en el segundo verso se añade un et, que podría deberse a cuestiones puramente musicales. Transcribo el motete completo y subrayo en negrita los dos versos que nos ocupan (traslado el texto a partir de la partitura, evitando las repeticiones propias de la composición musical, https://www.uma.es/victoria/morales/ pdf/Morales-Veni_Domine_Et_Noli_Tardare.pdf):

Veni, Domine, et noli tardare.

Veni visitare nos in pace,

ut laetemur coram te corde perfecto.

Veni, Domine, et noli tardare:

sicut mater consolatur filios, et noli tardare,

et videbimus te, et gaudebit cor nostrum.

Veni ad liberandum nos,

Domine Deus virtutum.

Veni, Domine, et noli tardare

et ostende faciem tuam, et salvi erimus.

Veni, Domine, et noli tardare,

et relaxa facinora plebi tuae Israel.

Veni, Domine, et noli tardare.

Del mismo modo, Francisco Guerrero (1528-1599), alumno de Cristóbal de Morales, compuso otro motete, impreso en Sevilla (Martín Montesdoca, 1555, fol. 12), también bajo el título Veni domine et noli tardare, que dice así (destaco en negrita los dos versos en cuestión):

Veni domine et noli tardare, veni ad salvandum nos,

domine Deus noster, ostende faciem tuam et salvi erimus.

Sicut mater consolatur filios, ita consolaberis nos.

Veni Domine et noli tardare, et gaudebit cor nostrum

corde perfecto et noli tardare.

Como se puede observar, los dos versos citados por Galeas también están presentes en el motete, aunque no seguidos como en Morales (Llorens Cisteró, 1988, vol. VI, p. 23). Desconocemos si Galeas pudo haberse inspirado en algunos de estos dos motetes, pero nos resistíamos a no dejar apuntada o sugerida esa posibilidad. 
Aquí se abre una cortina y se descubre el nascimiento, donde está la Virgen Sanctissíma María, y nuestro bien, el niño Jesú desnudico, y el bienaventurado Joseph, y ángeles y pastores con instrumentos diversos de música, y cantan los ángeles y los pastores con los instrumentos de música los tercetos siguientes:

La gloria sea a Dios en las alturas y paz sea en la tierra a los humanos, que Dios de amor se dio a sus criaturas.

Llegaron los estremos soberanos de aqueste amor de Dios a tal grandeza que quiso a pobres hombres por hermanos.

Y como la mortal naturaleza a Dios que es inmortal se halló unida, pobreza vistió Dios y ella riqueza.

¡Los ángeles espancta ${ }^{124}$ su venida, admira a serafines tal mudanza, que muerte escoja Dios por darnos vida!

Luego se torna a cerrar la cortina, y Pobreza y sus hijos, mientras se cantan los tercetos, se van recogiendo hacia el nascimiento de modo que todo queda cubierto debajo de la cortina.

Laus Deo.

$$
\text { S. C. S. E. C. R. }{ }^{125}
$$

\section{Introito para la comedia y represéntalo uno que suele representar un Simple. Muy gracioso}

ENCABEZAMIENTO: Introito para la comedia y represéntalo uno que suele representar un Simple. Muy gracioso (fols. 132v-134v).

Pieza introductoria monologada de $80 \mathrm{vv}$. endecasílabos (agrupados en estrofas de cinco versos, donde solo riman, en consonante, el segundo y el quinto: $\left.A B C D B^{126}\right)$, recitado por "quien suele representar un Simple». Su estructura es la habitual en este tipo de introitos monologados: salutación laudatoria a los espectadores; captatio benevolentiae, mediante la justificación de la mezcla de lo «grave» y lo de «mediano regocijo» en la obra, y la solicitud de dispensa por las faltas; presentación del argumento; y petición de atención. Las variantes entre este Introito y el

124. espancta: 'admira, maravilla'.

125. S. C. S. E. C. R.: abreviatura latina (Sub Correctione Sanctae Ecclesiae Catholicae Romanae), que, además de figurar en la cabecera de cada página del ms., incluida en un doble rectángulo que la enmarca, se repite al final de esta pieza. Se trata de una versión abreviada de la protesta de fe del autor (véase García Aguilar, 2009)

126. La métrica de este Introito coincide con la empleada en el Introito para representación a la venida del III. ${ }^{\text {mo }}$ Arzobispo de Seuj. ${ }^{a}$ [...] (fols. 94r-95r), reseñado como pieza independiente en Reyes Peña, 2017, pp. 132-133. En la Sexta parte de la obra que aquel prologa, hay también una serie de versos endecasílabos agrupados en cinco estrofas de cinco versos, donde solo riman, en consonante, el segundo y el quinto. 
que precede la homónima representación del MS. B2603 (New York, The Hispanic Society of America) son bastante escasas, observándose, en líneas generales, igual que ocurrirá en el cotejo de ambas representaciones, un mayor carácter cultista en la escritura y una copia más cuidada en el Ms. Galeas. La terminología y la información suministrada en el encabezamiento del Introito es más precisa y más teatral en el Ms. Galeas (Introito para la comedia y represéntalo uno que suele representar un Simple. Muy gracioso) que en el MS. B2603 (Yntroito. Represéntalo quien suele hazer un simple).

He aquí el texto:

Introito para la comedia y represéntalo uno que suele representar un Simple. Muy gracioso

Señores muy illustres, quien se emplea en dar reglas de aviso al avisado parésceme que hace lo que hace aquel que al claro sol añade lumbre o siembra en lo que ya está bien sembrado.

También el que en la hora de alegría en cosas muy sentidas pone mano, lo mesmo es que querer mudar los tiempos: el otoño templado en el estío y en desabrido invierno el buen verano.

Por nuestro auctor lo digo, que querría tractar aquí esta noche cosas graves y al fin se ha reducido ${ }^{127}$ de mezclarlas con otras de mediano regocijo, que al buen gusto serán harto süaves.

Él me rogó que yo le ${ }^{128}$ recitasse en seso ${ }^{129}$ el Introito de su obra y no sé si conmigo ha de acabarlo ${ }^{130}$, porque hablar no sufre muy en seso el que de seso ${ }^{131}$ tiene poca sobra.

No digo que me falta, mas que hago con gracias y locuras miles locos, a unos cuando hago del valiente, a otros cuando un simple represento, pues en el apodar no pican pocos ${ }^{132}$.

127. v. 13 reducido: 'resuelto'.

128. v. 16 le: caso de leísmo.

129. v. 17 en seso: «con cordura y fuera de burlas» (Cov.).

130. v. 18 acabarlo, acabar: «conseguir, obtener, alcanzar» (Aut.).

131. v. 20 seso: 'cordura, juicio'.

132. v. 25 apodar: «comparar una cosa con otra» (Martín Alonso); pican, picar: «acudir a un engaño o caer en él» (DRAE). Es decir, el encarnar o transformarse en ciertos personajes tipos (como un loco, un valiente, un simple...) y actuar como ellos es muy del agrado del público. 


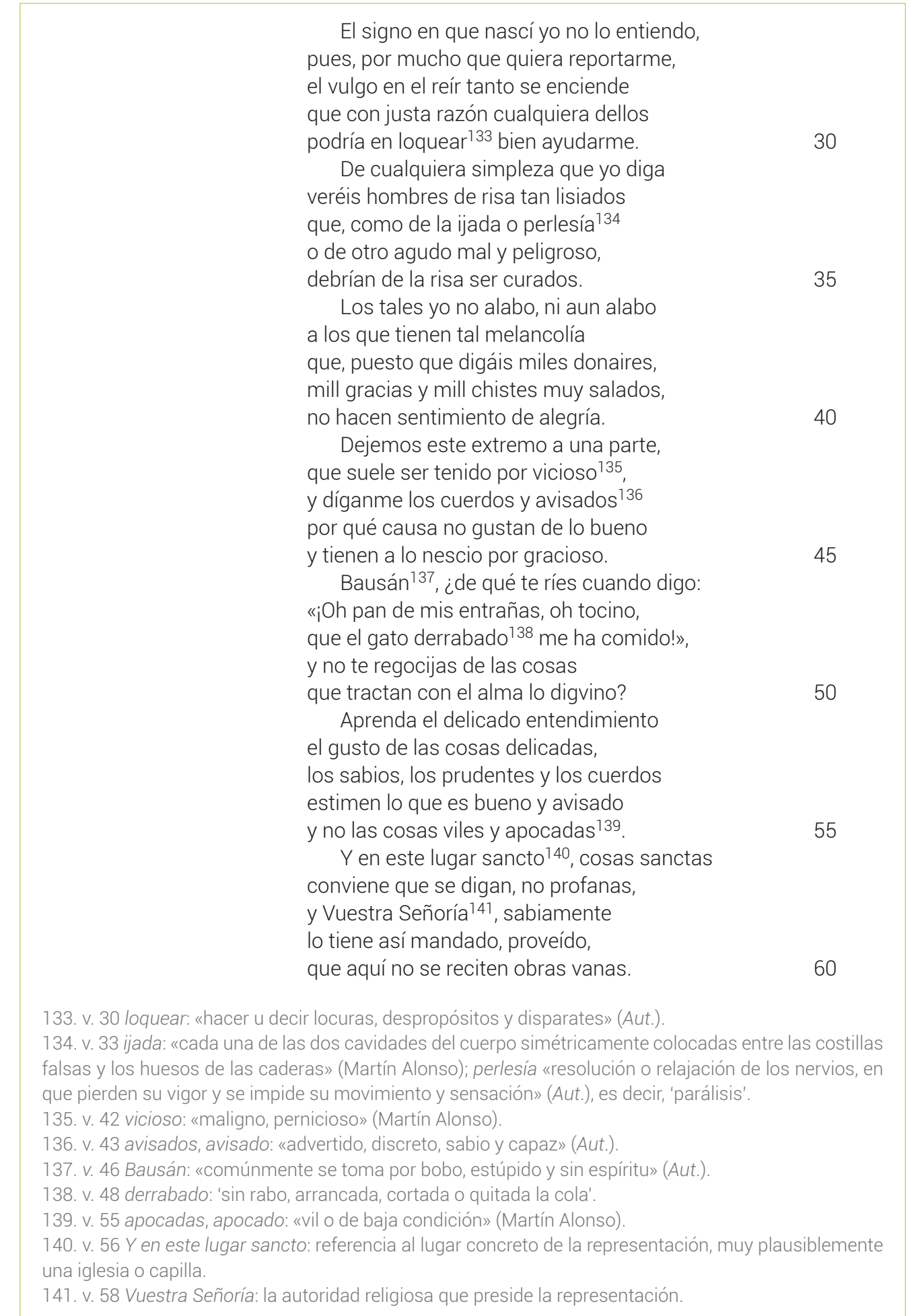

HIPOGRIFO, 9.1, 2021 (pp. 1187-1266) 
En esta buena noche ${ }^{142}$, tractaremos del alto nascimiento del bien nuestro ${ }^{143}$; y será el argumento cómo al Hombre, ciego por el Peccado, la Ignorancia lo truxo hasta la Ley como de diestro.

Y luego que la Ley fue publicada por ella cognosció el Hombre al Peccado y, porque cognoscido lo seguía después de la Ignorancia por Malicia, el Hombre hasta la Gracia fue guiado.

Venida pues la Gracia, se descubre una demonstración del nascimiento de tanta majestad y hermosura, tan grave y tan estraña en su grandeza que no puede al fiel no dar contento.

Por la attención, señores, suplicamos, y que se sufran faltas y rudeza, que solo por serviros os servimos, y en quien por amor sirve bien se emplea, le dé todo favor vuestra grandeza.

,


ESTRUCTURA: La obra está segmentada en seis partes, separadas por el vacío de personajes sobre la escena. Es decir, en pequeñas unidades cerradas, que, como sugería en la pieza anterior, es muy plausible que fueran pensadas por el autor para su sucesiva representación en los intermedios temporales existentes durante el rezo o canto de la liturgia de las horas canónicas.

ARgUMENTO: La pieza dramatiza la búsqueda de noticias por el Hombre caído acerca de su redención, que al fin llega con el nacimiento de Cristo. A lo largo de la misma, el Hombre se debate entre su esclavitud al Pecado y su deseo de apartarse de él, pues, aunque cegado por este - hijo del Hombre y de la adúltera Inobediencia-, conserva parte de la clara lumbre de la Ley natural que Dios le imprimió en su creación. Guiado por Ignorancia, que con sus necedades pone una nota de comicidad en la pieza, busca incesantemente a Prophecía para conocer la hora en la que llegará el remedio a su mal. Sin embargo, el Pecado lo distrae con continuos regocijos (un baile de villanos y «serranicas» y otro de momos) para que olvide su propósito. Prophecía, que entra acompañada de su hermana la Ley divina, ratifica al Hombre la promesa de redención. Mientras llega el momento, la Ley divina le mostrará la causa de su mal para que se aparte de él. Conocido y rechazado el Pecado por el Hombre y abandonada la Ignorancia, la Ley divina se ofrece como su lazarillo hasta la llegada de la Ley de Gracia con el nacimiento de Cristo, que le devolverá la vista y quebrará la cabeza al Pecado. No obstante, la Ley divina advierte al Hombre que, si ahora que conoce el Pecado lo sigue, en vez de Ignorancia lo servirá Malicia y será más culpable de sus actos. Y así sucede, pues el Hombre, sujeto otra vez al Pecado y guiado por Malicia en una escena situada en Sevilla, lamenta de nuevo su perdición y la de la ciudad hispalense, pintada por Malicia con muy vivos colores. Para distraerlo, el Pecado acude con un Charlatán, caracterizado como un lococuerdo que desenmascara a Malicia y vuelve a poner una nota de comicidad en la pieza. Ante una nueva petición de ayuda divina por el Hombre, acude la Prophecía con la Ley de Gracia, que anuncia su redención por el nacimiento de Cristo.

GÉNERO: Auto alegórico para festejar el nacimiento de Cristo, aunque en el Introito se le denomine comedia. También en la Comedia intitulada Triunfo de Pobreza contra Riqueza (fols. 110r-132r), igualmente estructurada en diversas «Partes» separadas por vacíos escénicos de personajes, se emplea dicho término -comedia-, a diferencia de las restantes piezas aquí tratadas, de menor extensión y mayor unidad dramática. Parece como si el autor en ambos casos estuviera experimentando con una especie de segmentación dramática en escenas, a través de estas extensas divisiones en «Partes», a cuya posible funcionalidad ya hemos aludido; las cuales, a su vez, se segmentan en unidades menores mediante el canto y cortos pasajes de entretenimiento. Estos, ejecutados por personajes de la vida cotidiana de los espectadores, contribuyen a que los personajes alegóricos protagonistas de la pieza, pues son conceptos, cobren una vida más real, apoyada de forma prioritaria por su lenguaje en prosa, sencillo, vivo, ágil, fluido y directo que se identifica con el lenguaje diario usado por los asistentes al espectáculo. 
TEATRALIDAD: La tensión dramática reside en el personaje del Hombre, dividido entre su irrefrenable sujeción al Pecado y sus ansias de liberación de dicha esclavitud, si bien aminorada ante los espectadores que conocen desde el principio que el nacimiento de Cristo proporcionará final feliz a la pieza. Las acotaciones implícitas y explicitas muestran al dramaturgo dueño de la puesta en escena. Entre las explícitas, además de las que marcan la segmentación de la obra y la entrada de personajes en escena, aparecen estas tres, que merecen destacarse: las dos primeras por dar entrada en la pieza a personajes populares con los que los espectadores estaban familiarizados, ejerciendo sus actividades habituales, y la última por incidir en la puesta en escena que lleva implícita el texto:

- Aquí entran los villanos y serranicas y tañen y bailan, y vanse con el Peccado (fol. 143v).

- Aquí entran los momos, bailando como matachines y juegan al abejón y vanse; y luego entran cantando la Ley y la Prophecía (fol. 148v).

- Aquí se descubre el sanctíssimo nascimiento en la vara de Jessé, llena de reyes, patriarchas y profetas y en lo alto la Virgen Sanctíssima María con el Niño Jessú Salvador Nuestro en los brazos, todos vivos, y entre tanto que está descubierto canta el Hombre con instrumentos este terceto (fol. 165r).

La conversión del espacio de ficción en espacio escénico en el caso de esta última acotación conllevaba una cierta complejidad escenográfica, tanto por el decorado requerido - vara de Jessé- como por la utilización en él no de figuras de bulto o pintadas sino de carne y hueso - «todos vivos»-; al menos que su lugar de representación fuese una iglesia o capilla, donde el árbol de Jessé estuviera pintado o esculpido.

FINALIDAD: Pieza de carácter doctrinal para celebrar el nacimiento de Cristo, con una sibilina crítica en boca de Malicia a la maldad que se encerraba en la ciudad de Sevilla, ciudad a la que llega el Hombre en ese caminar o deambular que marca su búsqueda y que culmina con su llegada a ella: Malicia le muestra la ciudad. De alguna forma, salvando las distancias, nos recuerda al pasaje bíblico en el que el Diablo le muestra a Jesús todo el esplendor terrenal. Y Sevilla de alguna forma debía ser una imagen de ese esplendor. Aunque la obra aparece salpicada por la comicidad en algunos pasajes, su tono es serio, respondiendo a lo que el prologuista en nombre del autor advierte en el Introito (vv. 1-15). Es decir, se trata de justificar la presencia de lo ridículo junto a lo grave, mezcla que se estima legítima para la ocasión, si bien de forma comedida, por respeto al lugar de representación y al cumplimiento de lo ordenado (vv. 56-62 del citado Introito). 
He aquí el texto:

Representación del nascimiento de Jesuchristo Salvador Nuestro. Es el argumento que el Hombre, ciego por el Peccado, fue guiado por la Ygnorancia hasta la Ley y, cognoscido el Peccado, lo guió la Malicia hasta la Gracia, en la cual cobró la vista muerto el Peccado, y concluye con la demonstración del sancto nascimiento en la vara de Jessé.

PRIMERA PARTE, en que se introducen el Hombre ${ }^{144}$ y el Peccado ${ }^{145}$.

HomBre.- Amantíssimo hijo mío, son tantos los benefficios que por tus manos rescibo, tan excessivo el amor que me muestras, tan continuos los servicios que me haces que no solo con el mesmo amor mas con los mismos servicios, si de padre a hijo se sufriessen, querría pagarte, porque al bien la gratitud es muy debida y amor con solo amor puede pagarse.

Peccado.- Hombre mortal, señor mío, si tienen algún valor mis servicios, de tu extimación los tienen, que de suyo poco valen; y, si por servirte a ti, mi vida y cien vidas arresgase según lo que meresces, yo sé que a lo que debo no llegasse, mas de merced te pido que me digas cuál es el fin que pretendes en referir agora lo que has dicho, que, por ser en ti cosa nueva, muy nueva admiración causa en mí.

\section{Villancico}

¿De qué te espantas?, di, di, traïdor Peccado.

¿De qué te espantas?, di, di de qué te has asombrado.

HOMBRE.- Mira, hijo, yo quiero tractar contigo muy llana y muy libremente lo que siento que el buen padre con su hijo sin doblez y sin respecto ${ }^{146}$ ha de tractar.

Peccado.- Di, señor, lo que quisieres.

HOMBRE.- Has de saber, hijo mío, que, estando en mi compañía dos muy preciosas doncellas que Justicia e Innocencia se llamaban y con muy graciosos dones me honrraban y enrriquescían, de mí te parió tu madre, la adúltera Inobediencia, y en la hora que nasciste de pesar de verte a ti las dos hermanas doncellas triste y solo me dejaron y se absentaron de mí.

144. Hombre: el Hombre como tal no aparece en la Iconología de Ripa, sí figura, en cambio, Cuerpo humano con el sentido del cuerpo unido al alma: «[...] figura de un hombre coronado de flores de ligustro, que va pomposamente vestido y llevando en una mano una linterna de tela - de las que suben y bajan-, viéndose esta apagada y con la siguiente leyenda: A lumine vita» (Iconología, t. I, p. 247).

145. Peccado: Ripa lo describe con estas palabras: «Joven ciego y desnudo que ha de ser de tez negra, al que se ve caminando por unas sendas peligrosas y torcidas. Irá ceñido de través por una sierpe, pintándose en su costado izquierdo la figura de un gusano que, penetrándolo dentro, le ha de estar royendo el corazón» (Iconología, t. II, pp. 187-188, la cita en p. 188). Aunque el personaje de Pecado en Galeas no es ciego, no deja de ser casual que el Hombre que vive en pecado se presente en la obra ciego. ¿Se transfiere esta cualidad de un personaje a otro?

146. respecto: «miramiento, veneración, acatamiento, que se hace a alguno» (Aut.). 


\section{Villancico}

Absentes tienes de ti

tales doncellas, pastor.

¡Ay que sí por mi dolor!

Peccado.- A lo menos, señor mío, cual soy y cual fue mi madre tú no me puedes negar que soy tu hijo.

HOMBRE.- Bien sé que yo te engendré y sé que la Inobediencia fue tu madre; sé que me sirves y que me regalas y que al voto ${ }^{147}$ de mi carne me haces cien mill placeres. Y con todo esto, no sé quién te eres; no te cognozco; no te entiendo; alégrasme y en lo que me alegras me entristeces; sírvesme y muy a mi gusto, y tu servicio me desagrada; téngote por bueno y sé que eres malo y, sabiendo que eres malo, te amo como bueno. De tal suerte me confundes para poder entenderte que, si por siervo te quiero, hallo que eres mi señor $y$, viendo que eres mi señor, entiendo que eres esclavo.

Peccado.- ¿Hay más que decir de mí?

HOMBRE.- Sabes que más; que no solo por tu causa perdí a Inocencia y Justicia, pero, en lugar de estas dos, a la Culpa y la Ignorancia me parió tu mala madre.

\section{Villancico \\ ¡Maldita sea la madre que tales hijos pare!}

HomBrE.- Una cosa he notado de ti, que te has conmigo como hombre vicioso que entre virtuosos se halla, que no se osa apartar de ellos porque no digan quién es. Andas tan vigilantíssimo en no apartarte de mí que, por más que yo trabajo de tenerte un hora absente y de absconderme de ti, adonde quiera que voy te hallo luego presente por testigo contra mí.

Peccado.- Señor, aunque me da pena ver cuán mal sientes de mí, una cosa me consuela: que tienes bien entendido que te sirvo y te regalo y, si por servirte yo, daño rescibes, a ti se debe imputar o a tu desgraciada suerte, y no a mí.

Hombre.- Muy bien dices, hijo mío, muy bien dices. Yo sé que tengo la culpa deste mal que tú me causas.

Peccado.- Pues, señor, si tanto daño rescibes de mi servicio, dame licencia. Irme he a buscar a quién servir.

HOMBRE.- No quiero, porque aventuro a perderte.

PECCADO.- ¿Por qué no aventuras a perderme, pues de perderme no pierdes y pierdes por no perderme? ${ }^{148}$

HOMBRE.- ¿Quieres que diga por qué?

Peccado.- Sí, señor.

147. voto: «Se toma algunas veces por lo mismo que deseo» (Aut.)

148. Juego con el término perder, empleado por el Peccado en cinco ocasiones en un parlamento muy breve. Es decir, por qué razón temes o no te atreves a que me vaya de tu lado, si yéndome, abandonándote, no pierdes nada, es más incluso ganas, y, en cambio, si me quedo pierdes con seguridad. 
HOMBRE.- Eres el mayor gitano ${ }^{149}$ engañador que crió naturaleza. No hay hechicero en la tierra que contigo se compare, el canto de la serena ${ }^{150}$ y la voz del encantador no echan tan grave sueño como tú. Dasme unos bebedizos tan sabrosos y tan dulces que, entendiendo que hay en ellos ponzoña que mata el alma, ando muerto por bebellos. Con hechizos, me enhechizas tan delicados y tales que, sabiendo que están llenos de un veneno mortal, como si diessen la vida, la vida te doy por ellos. ¿Puede haber mayor hechizo?

PECCADO.- ¿Pues qué te piensas hacer en tanta perplejidad?

HomBRE.- Esperar, que hay Dios que puede curar este mal y, aunque yo agora no alcance el cómo será ni el cuándo, en Él espero el remedio para poder cognoscerte, que no permitirá Dios que por tiempo para siempre esté en esta obscuridad, y, con tanto ${ }^{151}$, hijo mío, a la posada nos vamos .

Peccado.- ¡Vamos mucho en buena hora!

Villancico

¡Desdichado del que mora

en compañía tan mala

que mata cuando regala!

SEGUNDA PARTE, en que se introducen el Hombre y la Ignorancia ${ }^{152}$ y el Peccado, y viene ciego el Hombre.

Villancico

¡Ojos claros tiene el Hombre, pero no vee con ellos,

que el Peccado es señor dellos!

HomBRE.- Ignorancia, hijo mío, bien sabes he perdido la vista que Dios me dio $y$, pues me cabes en suerte para regirme y guiarme, hazme agora este placer de llevarme a la posada do mora la Prophecía.

IGNORANCIA.- Padre mío, yo no sé dó posa aquesa señora.

HOMBRE.- Dime, ¿cognóscesla tú?

IGNORANCIA.- No, señor, no la cognozco.

149. gitano: 'embaidor que con atractivos engaños y zalamerías logra lo que desea, lo cual su víctima acepta sin poderse resistir, aun a sabiendas de que está siendo engañado'.

150. serena; 'sirena'.

151. con tanto: me pregunto si en esta expresión habría un error de copia, siendo en tanto la lección correcta («mientras, ínterin o algún tiempo intermedio» [Martín Alonso, s. v. tanto]). Sin embargo, la he respetado ante la posibilidad de que pudiera significar 'y con esta creencia, con este pensamiento', que le acaba de comunicar el Hombre a Peccado, a la posada nos vamos.

152. Ignorancia: Para Cesare Ripa es «Mujer de rostro carnoso, muy disforme y ciega, que ha de tener en la cabeza una corona de Adormideras y ha de ir caminando descalza como si hubiera perdido su camino, avanzando por medio de un campo lleno de zarzas y de espinas. Irá vestida suntuosamente, adornada con oro y con piedras preciosas, viéndose a su lado un Vespertilio o Murciélago, que aparece volando». En otra descripción de la Ignorancia, añade: «Mujer similar a la anterior, pudiéndose añadir que su túnica ha de ir bordada con muchas escamas de Peces, pues dichos animales son verdadero símbolo de la Ignorancia, tal como puede verse en el lib. XXXI de Pierio Valeriano» (Iconología, t. I, p. 503). En Galeas, la Ignorancia es un personaje masculino («hijo mío»). 
HOMBRE.- Bien la habrás oído nombrar.

IGNORANCIA.- Ni aun nombrar nunca la he oído.

HOMBRE.- ¡Líbreme Dios del diablo!

IGNORANCIA.- (¡Y a mí me libre de vos!) [Aparte.]

HOMBRE.- ¿Qué es lo que dices, perdido?

IGNORANCIA.- Mas ¿qué es lo que vos decís?

HOMBRE.- Que me digas si cognosces a la preciosa doncella llamada Prophecía.

IGNORANCIA.- Decid, padre, ¿es una moza hermosa aguileñica de rostro?

HOMBRE.- Sí, hijo.

IGNORANCIA.- ¿La de unos cabellos largos con apretador ${ }^{153}$ de oro?

HOMBRE.- Sí, sí, hijo.

IGNORANCIA.- ¿Trae una saya de brocado y unos zapatos blancos plateados?

HOMBRE.- Es la misma.

IGNORANCIA.- ¿ESa?

HOMBRE.- Essa.

IGNORANCIA.- Pues no la cognozco 154

HOMBRE.- Mirad qué gentil consuelo para el hombre que perdió lo que yo, triste, perdí. (Quiero tractar de otras cosas para ver cómo responde.) [Aparte.] ¿Qué viento corre, Ignorancia?

IGNORANCIA.- Harto fresco.

HOMBRE.- ¿Cuál de los vientos?, te digo.

IGNORANCIA.- No cognozco yo más de uno.

HOMBRE.- ¿Y cuál es?

IGNORANCIA.- Es el viento.

HOMBRE.- ¿No le sabes otro nombre?

IGNORANCIA.- No le ${ }^{155}$ sé

HoMBRE.- ¿Adónde estamos agora? ¿Desde aquí véese el cielo?

IGNORANCIA.- No lo sé.

HOMBRE.- Pues, dime, ¿qué es lo que sabes?

IGNORANCIA.- Una cosa sola sé.

HOMBRE.- ¿Y cuál es?

IGNORANCIA.- Que no sé nada156.

153. apretador: «cinta o banda ricamente aderezada y labrada, que servía antiguamente de ornamento à las mujeres para recoger el pelo y ceñirse la frente» (Aut.).

154. Hombre.- Que me digas si cognosces... / IGNORANCIA.- Pues no la cognozco: Galeas en este diálogo entre Hombre e Ignorancia recurre a un equívoco cómico, de clara raigambre teatral, para provocar la risa en el espectador. Un empleo que nos muestra, una vez más, el conocimiento del hecho teatral de su autor que en un contexto alegórico provoca la risa del público para «relajar la escena» y llamar así su atención. 155. le: leísmo. Ignorancia es incapaz de modificar la forma del pronombre personal, ahora Objeto Directo, limitándose en su respuesta a repetir exactamente la misma forma empleada por el Hombre.

156. Esta contestación, antes de la intervención del Hombre, provocaría la risa del espectador. De alguna forma, la relación entre Hombre / Ignorancia recuerda en nuestra historia literaria la relación del Ciego y Lá- 
HomBre.- Si entendieras lo que has dicho, mucho has dicho, que decir que "solo sabes que no sabes» el sabio aqueso confiesa ${ }^{157}$, pero, por decirlo tú que no entiendes lo que dices, nada dices.

IGNORANCIA.- No, señor. No digo nada, ni entiendo nada, ni sé nada.

HOMBRE.- ¡Maldita sea la madre que tal hijo me parió, inhábil y sin provecho! Allégame a una parte y llamaré a los que pasan y quizá algún buen hombre me guiará a la Prophecía.

IGNORANCIA.- Eso sí, eso sí, padre. Llamad vos a quien quisierdes y no me pidáis a mí que haga lo que no sé.

Peccado.- (Iñorancia, he entendido que nuestro padre dessea verse con la Prophecía y que querría hallar quien a ella lo guiase.

IGNORANCIA.- Es verdad.

Peccado.- Pues yo lo desvelaré 158 con cosas de regocijo, de modo que no se acuerde de nada de lo que quiere y, entre tanto que yo vuelvo, aunque mill voces te dé, mira que no respondas sino hazte del dormido.

IGNORANCIA.- Soy contento y, en ser cosa de dormir, lo haré de buena gana.) [Aparte.]

HOMBRE.- ¡Ah, Ignorancia, Ignorancia, hijo mío!

IGNORANCIA.- No oigo, que estoy dormido.

HOMBRE.- ¿Passa alguien por ahí? ¿No respondes, Ignorancia?

IGNORANCIA.- Otra suya ${ }^{159}$ le dará. ¿No os digo que estoy durmiendo?

HOMBRE.- Hijo, Ignorancia, ¿qué es eso? ¿Hablas y dices que duermes?

IGNORANCIA.- ¡Qué gentil adivinar! Estoy durmiendo a placer y adivináis vos que hablo.

HOMBRE.- Dime, traidor alevoso, ¿quién te ha enseñado a mentir? ¿No respondes?

IGNORANCIA.- No, padre, que estoy durmiendo.

HoMBRE.- ¡Oh, gran Dios, y qué gran mal! (¿No veis cómo la Ignorancia es hábil para lo malo y para lo bueno inhábil? ¡Sin falta que aqueste mal lo causa la compañía de su hermano, con quien anda! ${ }^{160}$ ) [Aparte.]

Peccado.- Mi señor, no os congojéis, que por daros alegría os traigo aquí dos villanos con dos niñas serranicas que tañen, bailan y danzan con mill cuentos de donaires.

HOMBRE.- Holgaré mucho de oírlos.

IGNORANCIA.- Yo también de bailar. jAsí me consuele Dios, que lo sé muy bien hacer!

zaro (literatura picaresca). No solo por la comicidad, sino por el mismo hecho de poner a prueba al lazarillo. 157. Conocida máxima atribuida a Sócrates.

158. desvelaré, desvelar: «distraer» (Martín Alonso)

159. Otra suya: es decir, 'no se preocupe, que otra persona que pase y se dé cuenta le dará limosna'. 160. ¿No veis cómo ... con quien anda!: apelación directa al público con un carácter claramente aleccionador. 
Aquí entran los villanos y serranicas y tañen y bailan, y vanse con el Peccado.

HOMBRE.- Ignorancia, hijo mío, ¿estás aquí?

IGNORANCIA.- No, padre, no estoy ahí.

HOMBre.- Pues, ¿dó estás?

IGNORANCIA.- Aquí me estoy, que no ahí.

HOMBRE.- Hijo mío, ¿acuérdaste qué te preguntaba yo antes que este regocijo comenzase?

IGNORANCIA.- ¡Oh, qué donosa pregunta! ¿Yo me había de acordar?

HOMBRE.- ¡Ora, sus, vámonos, hijo, que el pasatiempo me ha hecho olvidar lo que tratacba!

IGNORANCIA.- Entrémonos a cenar y no curéis ${ }^{161}$ de otra cosa.

HOMBRE.- Anda, hijo, y mira bien que vamos por buena vía.

Villancico

¡Pues Ignorancia es la guía,

mira, Hombre, cómo vas!

Cata ${ }^{162}$ que te perderás.

TERCERA PARTE, en que se introducen la Prophecía 163 y la Ley.

Villancico

Las dos preciosas doncellas,

la Ley y la Prophecía,

cantando vais de alegría.

PRoPHECÍA.- Mi hermana la Ley divina, tan grande es el regocijo que siento en el corazón de que te veo en la tierra para tractar con el Hombre que no hallo fuerza en mí para poder explicarlo. Supla, hermana, tu saber la falta de mis palabras, extimando el alegría que tu presencia me causa no solo por lo que digo mas por aquello que tú entiendes que yo quisiera decir.

LEY.- Prophecía, hermana mía, graciosamente has mostrado tu grandeza en decir tanto en tan poco, y el amor en la alegría con que lo das a entender y con muy grande razón pues sabes que soy venida para cumplir tu palabra.

PropheCíA.- ¡Bendita seas, Ley sancta, y bendito sea el Señor que te envió! Bien sabes, hermana mía, que el Hombre por el peccado del paraíso terreno fue expellido y la clemencia divina, consolando el desconsuelo que sentía, conmigo le prometió que de mujer nascería quien quebrase la cabeza al traidor que lo engañó, y el tiempo de esta promesa no es llegado. Resta agora que, porque el Hombre está ciego y no cognosce al Peccado, que la ceguedad le causa, le hagas aqueste

161. curéis: 'os preocupéis'.

162. Cata: 'Mira, advierte'.

163. Prophecía: Cesare Ripa la describe «según aparece pintada en una fachada de la Biblioteca de N. S., en el Vaticano», como «Mujer que lleva el rostro oculto por un velo, sosteniendo con la diestra juntamente una trompa y una espada desnuda, mientras coge con la siniestra una cadena que baja y cuelga de un Sol, que está puesto a su izquierda y por encima de ella. En la cabeza de la figura que decimos se verá una Paloma» (Iconología, t. II, p. 229). 
bien de dárselo a cognoscer, que, puesto que tú no puedas remediarlo, al menos podrá por ti cognoscerlo para recatarse ${ }^{164}$ dél.

LEY.- Por cierto, señora mía, que yo haga alegremente lo que mandas, pero dime, por mi amor, ¿en qué estado tiene al Hombre aquel traidor del Peccado?

PROPHECÍA.- ¿En qué estado? Que, teniendo lumbre clara de aquella ley natural en él por Dios imprimida ${ }^{165}$, lo tiene tan tonto y ciego que casi, casi, no atina a cosa buena; y, aunque del todo no es muerta en el Hombre aquesta lumbre, en comenzando a avivarse sus centellas, con infernales regalos procura luego apagallas, de suerte que el pobre Hombre, a quien Dios hizo señor de lo criado, es esclavo aherrojado del Peccado.

LEY.- ¡Oh mi Dios y mi alegría, qué admirable es tu bondad y tu amor cuán ineffable! ¡Oh cuán a tiempo me envías para que el Hombre perdido no se acabe de perder!

Prophecía.- Pues vamos, hermana mía, a su posada y tractaremos con él de su remedio.

LEY.- Vamos mucho en buena hora y cantando por mi amor.

\author{
¡Bendito seas, Señor, \\ y tu sancto y alto nombre, \\ que así miras por el Hombre!
}

CUARTA PARTE, en que se introducen Hombre, Ignorancia, Peccado, Prophecía y Ley.

HOMBRE.- Ignorancia, pues me dices que has aprendido ciencia, respóndeme agora bien a lo que te preguntaré.

IGNORANCIA.- Pregunte V. M. y note bien mis respuestas, y verá si he aprovechado.

HOMBRE.- Di, Ignorancia, ¿qué hicieras si te hallaras sin vista como yo?

IGNORANCIA.- Yo diera cuanto tuviera por unos ojos de lince.

HOMBRE.- ¿Aquesos ojos de lince al ciego qué le aprovechan?

IGNORANCIA.- Grandemente.

HOMBRE.- Dime cómo.

IGNORANCIA.- Pruébolo así. ¿Los hombres de corta vista no ponen sobre los ojos unos pedazos de vidrio y ven muy bien con ellos?

HOMBRE.- Así es.

IGNORANCIA.- Pues luego si con el vidrio, con ser una cosa muerta, vee bien el que mal vía, bien vale esta consecuencia: que con los ojos del lince que es la cosa que más vee y cosa viva, que verá un ciego con ellos.

HOMBRE.- ¡Oh qué donosa razón, qué viva y qué delicada! Muy bien paresce ser tuya, Ignorancia.

IGNORANCIA.- Sí, señor, mía es por cierto, porque, ila gloria sea a Dios!, tengo un claro entendimiento y hame aprovechado mucho haber estudiado un poco.

164. recatarse: 'recelarse'.

165. imprimida, imprimir: «fijar en el ánimo las especies» (Aut.), en nuestro caso la ley natural. Término aplicado a Dios de clara resonancia en la literatura religiosa y mística. 
HOMBRE.- ¿Qué sciencia has aprendido?

IGNORANCIA.- Philosophía y geometría, matemática y astrología ${ }^{166}$.

HomBre.- Pues sabes astrología, dime agora, ¿quién a cuál le da la lumbre, dásela el sol a la luna o la luna al sol?

IGNORANCIA.- Mire qué viva respuesta: o el sol se la da a la luna o la luna la da al sol.

HOMBRE.- Por cierto aquesa respuesta es sin respuesta.

IGNORANCIA.- Pues nunca digo yo cosa que vaya menos fundada.

HOMBRE.- ¿Y sabes en todas sciencias como en la de astrología?

IGNORANCIA.- Y aún mejor. Si no, oiga dos reglitas que diré de geometría.

HOMBRE.- Di, en buen hora.

IGNORANCIA.- Si en este número de doce caben once, en once bien cabrán diez $y$, si en los diez caben nueve, en nueve bien cabrán ocho. Mire si dijera más un Viturvio 167.

HOMBRE.- (¿No notáis cómo las letras son locas en hombre loco? ¡Oh desventurada vida, ved a quién tengo por ayo, por guarda, consuelo y guía! ¡Mi Dios, dame algún remedio, que de tus manos lo espero!) [Aparte.]

PECcAdo.- Mi señor, no toméis pena, que aquí vienen ciertos momos ${ }^{168}$ a jugar al abejón ${ }^{169}$. Pasaréis el tiempo un poco.

HOMBRE.- ¡Sea mucho en buen hora!

Peccado.- ¿Veislos? ${ }^{170}$ Vienen.

Aquí entran los momos bailando como matachines ${ }^{171}$ y juegan al abejón y vanse; y luego entran cantando la Ley y la Prophecía.

166. Se trata de disciplinas pertenecientes a las Ilamadas Artes liberales (concepto medieval heredado de la antigüedad clásica), de gran importancia para la formación intelectual del individuo por oposición a las artes serviles (artesanales o mecánicas) durante la Edad Media y la Edad Moderna. Las Artes liberales quedaron fijadas en siete, divididas en dos grupos: el Trivium (Gramática, Dialéctica y Retórica) y el Quadrivium (Aritmética, Geometría, Astronomía y Música).

167. Viturvio, Vitruvio: arquitecto, escritor, ingeniero y tratadista romano del siglo I a. C.

168. momos: 'figuras ridículas que con gestos, figuras o mofas ejecutados para divertir participaban en juegos, mojigangas y danzas'.

169. jugar al abejón: «el juego de que usa la gente rústica por entretenimiento, y se ejecuta entre tres personas puestas en hilera. El que está en medio abierto de piernas, y juntas las manos, moviéndose a un lado y a otro, hace un ruido con la boca al modo del abejón: amaga a uno de los dos que están en los lados que le esperan con un brazo levantado, y la mano del otro puesta en la mejilla, y da al que se descuida un golpe en la mano que tiene puesta en el carrillo; y si no hurta, y aparta tan presto el cuerpo, recibe otro del que le está esperando» (Aut., s. v. abejón).

170. ¿Veislos? Vienen: no deja de ser irónica esta intervención de Peccado preguntando a un ciego si ve venir al grupo de momos, lo que provocaría sin duda la risa en el auditorio.

171. matachines, matachín: «hombre disfrazado ridículamente con carátula, y vestido ajustado al cuerpo desde la cabeza a los pies, hecho de varios colores y alternadas las piezas de que se compone: como un cuarto amarillo y otro colorado. Fórmase destas figuras una danza entre cuatro, seis u ocho, que llaman los matachines, y al son de un tañido alegre hacen diferentes muecas, y se dan golpes con espadas de palo y vejigas de vaca llenas de aire» (Aut.). 


\begin{tabular}{|c|c|}
\hline & $\begin{array}{l}\text { Villancico } \\
\text { ¡Si no sientes las traiciones } \\
\text { del traidor con quien estás, } \\
\text { Hombre, ciego, ciego vas! }\end{array}$ \\
\hline $\begin{array}{l}\text { HOMBRE. } \\
\text { ¿si fuese Pro }\end{array}$ & sica tan graciosa! El corazón me ha tocado su dulzura. Mas, \\
\hline PROPHEC & re, yo soy. ¿Qué me quieres? \\
\hline HOMBRE. & dadme las manos, besarlas he de rodillas. \\
\hline PROPHEC & o, di lo que quieres. \\
\hline HOMBRE. & que me digáis cuándo llegará la hora del remedio de mi mal. \\
\hline $\begin{array}{l}\text { PROPHEC } \\
\text { por ser quier } \\
\text { cognozcas e } \\
\text { y remediarte } \\
\text { cognoscer qu }\end{array}$ & $\begin{array}{l}\text { rte, Hombre, y entiende que el que de nada te hizo te ama } \\
\text { o que Él te prometió sin falta lo cumplirá, y, porque mejor } \\
\text { amor que te tiene, en tanto que el tiempo llega de curarte } \\
\text { su sancta Ley, mi hermana, que está presente para darte a } \\
\text { a el mal que padesces para que te apartes de él. }\end{array}$ \\
\hline HOMBRE & $\begin{array}{l}\text { ¡Tu vos }{ }^{173} \text { suene, señora, en mis oídos! } \\
\text { ¡Entónenme tus labios con clamores } \\
\text { la causa que da causa a mis gemidos! }\end{array}$ \\
\hline LEY & $\begin{array}{l}\text { Amigo, has de saber que tus dolores } \\
\text { el hijo que ante ti tienes presente } \\
\text { los causa y causará otros mayores. } \\
\text { En él tu amor se emplea vanamente, } \\
\text { pues todos los regalos que te hace } \\
\text { halagos son de cola de serpiente. } \\
\text { Lo bueno que en ti hay él lo deshace, } \\
\text { lo malo solo él es quien lo ha planctado, } \\
\text { lo que a virtud agrada a él desplace. } \\
\text { Su nombre has de saber que es el Peccado, } \\
\text { aqueste tractarás como a enemigo, } \\
\text { pues bienes inmortales te ha quitado. }\end{array}$ \\
\hline HOMBRE & $\begin{array}{l}\text { ¡Bendito sea mi Dios que tan amigo } \\
\text { se muestra al que offendido le tenía, } \\
\text { abriéndole las alas de su abrigo! } \\
\text { Y vos, traidor Peccado, a quien solía } \\
\text { amar tan sin razón, ya que os cognozco } \\
\text { yo quiero que dejéis mi compañía. }\end{array}$ \\
\hline IGNORAN & tú eres el Peccado? ¡Dios me libre del diablo! \\
\hline PECCADO & ermano. \\
\hline IGNORAN & nano seas tú del verdugo! ¡Vete de aquí, bergantazo ${ }^{174 !}$ \\
\hline LEY.- ¡Pu & nbién os iréis, que no tenéis de servir más al Hombre! \\
\hline $\begin{array}{l}\text { 172. por ser quien es } \\
\text { repetición de términ } \\
\text { 173. vos: fenómeno } \\
\text { 174. bergantazo, aur } \\
\text { condición no solo vil }\end{array}$ & $\begin{array}{l}\text { or (que el que de nada) ser quien es (fol. 149v), con un evidente error de } \\
\text { diatamente los preceden, situados aquí entre paréntesis. } \\
\text { el sustantivo bergante: «picarón, sin vergüenza, de malas costumbres, y } \\
\text { sa y maliciosa» (Aut.). }\end{array}$ \\
\hline
\end{tabular}


IGNORANCIA.- ¡Por vida de V. M.!

LEY.- No, en verdad.

IGNORANCIA.- ¡Así Dios le guarde!

LEY.- ¡Assí Dios me guarde!

IGNORANCIA.- Padre, ¿queréis que me vaya?

PROPHECÍA.- ¡Anda, tira ya de aquí!

IGNORANCIA. - Ya me voy. ¡Válame Dios!

HOMBRE.- Mi señora la Ley sancta, pues ya cognozco el Peccado y la Ignorancia es ida, decid quién me ha de guiar.

LEY.- Yo seré tu pedagogo hasta que venga en buen hora la Ley de Gracia, mi amada, que comenzará a reinar cuando nazca el «Desseado» de las gentes, el cual te dará la vista, y al demonio y al Peccado la cabeza quebrará; pero advierte que, si al Peccado sigues agora que lo cognoces, en lugar de la Ignorancia te servirá la Malicia y assí lo que para bien Dios por mis manos te ha dado más culpable te hará.

PRophecía.- Dalde la mano, señora, llevémoslo a su posada.

LEY.- Darla he con alegría.

\section{Villancico}

¡Oh qué venturosa suerte, qué buena dicha la mía, que tan preciosa doncella sea mi guarda y mi guía!

QUINTA PARTE, en que se introducen el Hombre y la Malicia ${ }^{175}$ y el Peccado, y un Charlatán.

HOMBRE.- Di, Malicia, ¿qué haré, que traigo un grande dolor de cabeza?

MALICIA.- Ese mal es sin remedio.

HOMBRE.- ¿Y el porqué?

MALICIA.- Porque vieja enfermedad es incurable.

HomBre.- No ha dos horas que me dio. ¿Cómo dizes tú que es vieja?

MALICIA.- Más ha de los años treinta que siento yo que tenéis esse dolor ${ }^{176}$

HOMBRE.- Por cierto, tal no he sentido.

MALICIA.- Tenéislo y no lo sentís, y esse es más grave dolor.

175. Malicia: bajo el lema Malignidad, sinónimo de Malicia, Cesare Ripa describe una «Mujer pálida y fea, vestida con un traje del color de la herrumbre. Sostendrá una codorniz con ambas manos, sujetándola en alto, con la cabeza puesta en dirección al cielo y alas abiertas» (Iconología, t. II, p. 41). En Galeas, Malicia es un personaje masculino («Nescio yo», «traidor»).

176. Creemos que Malicia se está refiriendo a los años treinta de la era cristiana, que -recordemoscomienza con el nacimiento de Cristo. A los 30 años de dicha era, Cristo comienza su ministerio público, con el bautismo que recibe de San Juan el Bautista (Mateo, 3, 13-17; Marcos, 1, 9-11; Lucas, 3, 21-22; Juan, 1, 29-34), que finalizará con su pasión, muerte y resurrección, el precio pagado al Padre por el pecado cometido por el Hombre, que le devuelve la posibilidad de conseguir la vida eterna tras su vida terrenal, si su muerte se produce en estado de gracia. Desde ese momento, Malicia sabe que el Hombre siente ese dolor, aunque no sea consciente de él. 
MALICIA.- ¿De vano? ¡Nunca Dios quiera!

HOMBRE.-¿Pues de qué?

MALICIA.- De muy excelente loco.

HOMBRE.- ¡Qué honrradamente me tractas! ¡Dios te dé mucha salud!

MaLICIA.- Aquesa tal os dé Dios.

HOMBre.- Di, Malicia, ¿dónde estamos?

MALICIA.- ¿Adónde estamos? En aquella gran ciudad que cerca del río Betis ${ }^{178}$ se cuenta que edificó Híspalo ${ }^{179}$, su rey primero, do las columnas plantó Hércules ${ }^{180}$, el muy famoso.

HOMBRE.- ¡Oh Dios, y quién tuviera mis ojos para miralla! ¡Oh qué templo!181, ¡oh qué torre! ${ }^{182}$, joh qué gradas! ${ }^{183}$, ¡oh! que río ${ }^{184}$, iqué grandeza!, iqué edificios!, ¡qué de oro!, iqué de plata!, iqué de señores! y iqué pueblo! Por cierto que es admirable su hermosura ${ }^{185}$.

MALICIA.- Decís muy grande verdad, pero dejáis muchas cosas principales que en aqueste pueblo hay.

HOMBRE.- Dilas, así Dios te guarde, que rescibiré alegría.

MALICIA.- Hay muy grande sanctidad, grande paz, muy buen gobierno, espantable ${ }^{186}$ charidad, muy grande recogimiento, gran templanza, gran vergüenza y admirable honestidad. Esto todo está sobrado y de lo contrario hay poco ${ }^{187}$.

HOMBRE.- ¿Cómo así?

177. motejado: «censurado» (Aut.)

178. río Betis: el río Guadalquivir que atraviesa la ciudad de Sevilla. Fue conocido como río Betis desde la época prerromana y los árabes le dieron el nombre de Guadalquivir a partir del siglo XI.

179. Híspalo: personaje mitológico, al que se le atribuye la fundación de Hispalis (Sevilla), siendo su rey primero.

180. Hércules: nombre latino del griego Heracles, «el héroe más célebre y popular de toda la mitología clásica», hijo de Alcmena y de Zeus (Grimal, 1981, pp. 239-257, la cita, en p. 239, s. v. Heracles; ver también Hércules, s. v., p. 260). Hércules se tiene por el mítico fundador de la ciudad de Sevilla. En 1574, en la zona meridional de la denominada «Alameda de Hércules» desde 1845, «se levantaron, a modo de entrada, dos columnas traídas del templo romano de la calle Mármoles y sobre ellas se colocaron sendas esculturas [...] que representan a Hércules, mítico fundador de la ciudad, y a Julio César, a quien se atribuye la renovación urbana de Híspalis y la construcción de su muralla» (Diccionario histórico de las calles de Sevilla, 1993, t. I, pp. 40-47, s. v. Alameda de Hércules, la cita en p. 40).

181. templo: referencia a al templo catedralicio.

182. torre: referencia a la Giralda.

183. gradas: referencia a las gradas que rodean el exterior de la fachada de la Catedral hispalense 184. río: referencia al río Guadalquivir.

185. En este parlamento, el Hombre, ahora ciego, se lamenta de no poder ver la ciudad, que evoca desde el recuerdo.

186. espantable: 'excelente, admirable'.

187. Es decir, de todo lo bueno que acaba de enumerar Malicia hay mucho, en exceso, y de lo contrario, lo malo, hay poco. La causa como explica Malicia reside en que lo bueno sobra porque lo practican pocos, y lo malo falta porque lo sigue la mayoría. 
MALICIA.- Porque todo aquesto bueno que os he dicho hay muy pocos que lo quieran y por esto está sobrado. De lo contrario, que es malo, hay muy poco, porque lo siguen los más.

HomBrE.- Ya me espantaba, Malicia, que malicia no dijeses. Mas, de otra cosa me espancto mucho más.

MALICIA.- Di de qué.

HOMBRE.- De ver que en una ciudad tan insigne como esta permitan entrar en ella a una cosa tan mala como tú.

MALICIA.- Por cierto, vos levantáis a esta noble ciudad testimonio ${ }^{188}$, que a mí no me dejan entrar.

HOMBRE.- ¿Cómo no?

MALICIA.- Porque yo no salgo della y assí no tengo a qué entrar.

HOMBRE.- ¿Que en ella resides tú?

MALICIA.- Y muy de asiento ${ }^{189}$ y tengo amigos en ella muy cabales.

HOMBRE.- ¡Oh grande infelicidad! Yo la cognoscí sin ti; pero al fin esos tus amigos serán de la gente baja y de bajo entendimiento, porque en noble corazón no cabrá tanta maldad.

MALICIA.- ¿Queréis decir que serán solos necios maliciosos? ${ }^{190}$

HOMBRE.- Así me paresce a mí que debría ello de ser.

MALICIA.- Pues engañado vivís, porque la gente de lustre, la prudente y avisada y la rica, aquesta es la principal que me sigue.

HOMBRE.- ¿De dónde vino a este pueblo este decir y hacer de malicias?

MALICIA.- El decirlas, del ocio y curiosidad; y el hacerlas, del interesse y cudicia.

HOMBRE.- ¡Oh Malicia, qué gran mal que haces a aqueste pueblo! Con lágrimas, y de sangre, debría yo de llorar su perdición y la mía.

Peccado.- ¿Qué es aqueso, mi señor? No toméis agora pena, que aquí viene un Charlatán y os dirá miles donaires de que rescibáis contento.

MALICIA.- Dirá él mala ventura.

CHARLATÁN.- Vos soys la mala ventura, que yo no soy sino buena, buena estrena $^{191}$, luna llena, alegre cena, canto de serena, y mirad, nescio, mirad no me deis pena, cantad, que os haré andar a la melena ${ }^{192}$.

188. levantáis ... testimonio, levantar testimonio: «falsa atribución de alguna culpa» (Aut.).

189. de asiento, estar de asiento: «Estar establecido en un pueblo o lugar» (DRAE)

190. Es decir, ¿que solo los necios, ignorantes y de baja condición serán los maliciosos?

191. estrena: «la dádiva, alhaja o presente que se da, en señal y demonstración de algún gusto, felicidad, o beneficio recibido» (Aut.).

192. andar a la melena: 'obligar a que se ejecute algo que no se quería hacer'. El característico hablar del Charlatán con su sucesión de palabras que riman podrían tener una base en libros similares al Arte poetica española: con vna fertilissima sylva de consonantes comunes, propios, esdruxulos y reflexos y vn divino estimulo del amor de Dios, de Juan Díaz Rengifo, Salamanca, Miguel Serrano de Vargas, 1592, donde se recogen listados de palabras que riman entre sí. Libros de este tipo serían de uso habitual en autores de la época. 
MALICIA.- ¿Nescio yo? ¡Pluguiera a Dios que lo fuera! Para holgarme y reírme de tus charlatanerías, como muchos que aquí están ${ }^{193}$. Se huelgan y se contentan ${ }^{194}$ de semejantes y otras necedades y a las cosas delicadas y sentidas dicen que es gran frialdad.

CHARLATÁN.- ¡Oh, traidor, malicia es essa!

MALICIA.- Pues ese es mi proprio nombre.

CHARLATÁN.- Malicia, malicia, avaricia, tericia ${ }^{195}$, nequicia ${ }^{196}$, pigricia ${ }^{197}$, y estulticia $^{198}$, y mirad, traidor, que entréis debajo desta milicia, si no yo os haré que andéis con la tristicia ${ }^{199}$.

MALICIA.- ¿Qué vanidades son essas, di, perdido?, que ni atas ni desatas ${ }^{200}$ en cosa de cuanto dices.

CHARLATÁN. - ¿Yo no ato ni desato? Vos sois un rato201 y un gato, malato202, mulato ${ }^{203}$, y garabato ${ }^{204}$. Y, si otra vez decís tal desacato, traeros he a mis pies un grande rato.

HOMBRE.- Por cierto que es muy donoso el Charlatán.

CHARLATÁN.- Sí, señor, soy muy donoso, gracioso, hermoso, prescioso, amoroso y virtuoso, y, si echáis de vuestra casa al malicioso, serviros he yo a vos muy de reposo.

HomBre.- ¿Qué es aqueso? Di, Malicia, paresce que estás corrido.

MALICIA.- Decís muy grande verdad, porque en casa de los necios mucho más privan $^{205}$ los locos que los sabios.

CHARLATÁN.- Vos sois el loco y el poco y el coco y el moco, y, si más reprehendéis lo que yo toco, un palo en la cabeza ${ }^{206}$ os embroco.

193. muchos que aquí están: en el ms. muchos aquí están (fol. 155v), que el MS. B2603 lee bien (fol. 33r). 194. contentan: en el ms. contan (fol. 155v), que el MS. B2603 lee bien (fol. 33r).

195. tericia, ictericia: «Enfermedad que causa en el cuerpo una amarillez extraña, ocasionada de derramarse la cólera por las partes de él. Las especies de ictericia se toman de la diversidad del color y causa de donde nacen: la ordinaria y común es la amarilla (llamada también blanca a distinción de la que llaman negra), la cual nace de inflamación o destemplanza del hígado, o obstrucción de la vejiga que es depósito de la hiel. La negra nace de indisposición del bazo y opilación de la vena splénica, o de una mezcla extraña del humor colérico y melancólico» (Aut.).

196. nequicia: «maldad, perversidad» (Martín Alonso).

197. pigricia: «pereza, ociosidad, negligencia, descuido» (Martín Alonso).

198. estulticia: «locura, bobería, necedad y falta de juicio» (Aut.).

199. tristicia: «lo mismo que tristeza» (Aut.)

200. ni atas ni desatas, no atar ni desatar: «hablar sin concierto» (DRAE)

201. rato: «lo mismo que ratón» (Aut.).

202. malato: «el que está algo malo» (Aut.).

203. mulato: en germanía «espadachín o valentón» (Alonso Hernández, 1977, s. v.).

204. garabato: «gancho de hierro que, sujeto a una cuerda, se lanza a lo alto de un muro para engancharlo a él y poder escalarlo. Es un instrumento utilizado por el ladrón nocturno» (Alonso Hernández, 1977, s. v.), sinécdoque empleada por el Charlatán para tachar a Malicia de 'ladrón'.

205. privan, privar: «tener valimiento y familiaridad con algún Príncipe o superior, y ser favorecido dél» (Aut.).

206. cabeza: en el ms. cabera (fol. 156v) que el MS. B2603 lee bien (fol. 33v). 
MALICIA.- Charlatán, yo te he mancilla207, viendo cuán vil y cuán bajo es el officio que traes.

ChARLATÁN.- Hablemos un poco en seso, Malicia, pues reprehendes mi oficio que es el tuyo.

MALICIA.- Sacar las cosas secretas a lo raso para ver el mal o el bien que en ellas hay, decir cosas delicadas a su tiempo, tener siempre un buen palacio, no sufrir hipocresía y desterrar necedades y locuras aqueste es mi proprio oficio.

CHARLATÁN.- ¡Oh, traidor, y cómo cuentas lo que es dulce y lo que es tierno y cómo sabes callar lo que es amargo y lo duro! Mas yo te diré quién eres, porque entiendas que te entiendo, aunque me tienes por loco.

MALICIA.- ¡SUSO!, pues, dime quién soy.

CHARLATÁN.- Eres la más mala bestia que hay en naturaleza, la ponzoña de la víbora si se compara a la tuya es como atriaca 208 ; áspides ${ }^{209}$ y basiliscos ${ }^{210}$ ante tu cruel braveza son corderos. ¿Qué obra tan buena habrá que tu traición no condene? ¿Qué palabra tan sencilla que tu maldad no calumnie? Eres malo y juzgas las intenciones por la tuya y quedan siempre por malas, porque la tuya lo es. En fin, me paresces que eres al corte ${ }^{211}$ que suelen decir mula brava y mala, y mala mujer, brava, maliciosa, rijosa, briosa, revoltosa, cavilosa y peligrosa, y sabed, traidor, por cierta cosa que peor sois mucho vos que la raposa 212

MALICIA.- Pues yo os quiero responder.

PECCADo.- ¡Ya no más, que se hace tarde!

HOMBRE.- Bien dices. ¡Vámonos, hijo!

CHARLATÁN.- ¡Vamos mucho en hora buena y daremos en el pan²13!

\author{
Gracioso es el Charlatán, \\ hermano Juan. \\ Gracioso es el Charlatán \\ para truhan.
}

207. mancilla: 'lástima'.

208. atriaca, triaca: «composición de varios simples medicamentos calientes, en que entran por principal los trociscos de la víbora. Su uso es contra las mordeduras de animales, e insectos venenosos, y para restaurar la debilitación por falta del calor natural» (Aut.).

209. áspides, áspid: «especie de serpiente pequeña», cuya mordedura acarrea gravísimos y mortales accidentes (Aut.)

210. basiliscos, basilisco: «especie de serpiente [...]. Es fama vulgar que con la vista y resuello mata, por ser eficasísimo su veneno» (Aut.).

211. eres al corte: 'eres de las trazas, de la manera'. Recordemos que el verbo ser «junto con nombres o participios de otros verbos, vale tener las propiedades o calidades de lo que dichos nombres significan» (Aut.).

212. raposa: 'zorra'.

213. daremos en el pan. 'llegaremos a tiempo para comer', con el empleo del término pan en este sentido: «figuradamente se toma por todo lo que en general sirve para el sustento diario, por ser el pan el principal» (Aut.) 
SEXTA PARTE. Introdúcense el Hombre, Malicia, Peccado, Prophecía 214 , Ley de Gracia ${ }^{215}$ y al fin della se demuestra el nascimiento en la vara de Jessé.

Hombre.- Malicia, gran pena siento de ver que mande en mi casa el Peccado más que yo.

MALICIA.- No es el Peccado solo el que manda en vuestra casa más que vos.

HomBre.- Yo no sé quién puede ser, si tú, Malicia, no eres.

MALICIA.- Pues sabé que no soy yo.

HOMBre.- Pues ¿quién es?

MALICIA.- Es un mancebo gracioso que cuando tractáis con él os alegra el corazón y os hace del alegría salir colores al rostro.

HOMBRE.- De embriago ${ }^{216}$ me motejas ${ }^{217}$, Malicia, si no me engaño.

MALICIA.- Huélgome que me entendéis y que habéis dado en la cuenta ${ }^{218}$ como hombre experimentado.

HomBre.- Malicia, si fuera yo malicioso como tú, bien te pudiera decir: «Médico cúrate a ti»» ${ }^{219}$.

MALICIA.- Bien decís, pero no podéis negar que fuistes vos de mi malicia maestro.

HOMBRE.- Malicia, vete de aquí y déjame un rato solo.

MALICIA.- YO me voy.

HOMBRE

Mi Dios, el bravo mar de carne y mundo

con la fuerza del aire del peccado

me tiene tan adentro en lo profundo

que casi, casi todo estó anegado.

Mas, aunque toco a centro tan inmundo,

si de tu mano fuese yo aliviado,

en tu virtud espera mi esperanza,

que puede a tal tormenta dar bonanza 220

214. En el ms. pphecia (fol. 158r).

215. Ley de Gracia: bajo este lema, Cesare Ripa suministra la siguiente descripción: «Mujer sedente que ha de estar bendiciendo con la diestra. Sobre la misma mano se pondrá la paloma del Espíritu Santo, viéndose a la mujer acomodada sobre una gran vasija o recipiente de donde sale gran cantidad de agua. Encima de la vasija que decimos habrá varias Cornucopias, en cuya parte superior estarán representados los animales que corresponden a los cuatro Evangelistas. Además con la izquierda estará sosteniendo un libro abierto, dentro del cual se lee: In principio erat verbum» (Iconología, t. II, p. 16). Bajo el lema Gracia, Ripa ofrece su descripción, seguida de las correspondientes a Gracia divina y Gracia de Dios, de las cuales la relativa a Gracia divina, es la que estimamos de mayor facilidad para su escenificación: «Mujer hermosa y sonriente que ha de estar con el rostro vuelto hacia el Cielo, donde se ha de ver al Espíritu Santo tal como habitualmente se pinta, en forma de paloma. Con la diestra sostendrá una rama de olivo junto con un libro, sujetando además con la siniestra un Cáliz» (Iconología, t. I, pp. 465466, la cita en p. 465).

216. embriago: «borracho o embriagado» (Aut.).

217. motejas, motejar: 'tachar, censurar'.

218. dado en la cuenta, dar en la cuenta: «lo mismo que caer en la cuenta» (Aut.).

219. «Médico, cúrate a ti»: proverbio latino (Medice cura te ipsum), que se aplica a otro para que se reconozca a sí mismo con sus defectos y virtudes. Lucas 4, 23, pone este proverbio en boca de Jesús. 220. En la primera parte de la octava, el Hombre metafóricamente se considera a sí mismo como un navío a punto de irse a pique o hundirse en las profundidades del bravo mar, agitado por la fuerza del 


\section{Prophecía y Gracia entran cantando.}

¡Buen viaje, buen pasaje, mar, bonanza, que el remedio para el Hombre hoy se alcanza!221

PROPHECÍA.- Ley de Gracia, la graciosa, luz clara en el mediodía y clara en la noche obscura 222 , ¿quién habrá que a tu grandeza le dé bien el norabuena que meresce tu venida?

GRAcIA.- Ten silencio, Prophecía, que paresce que entra gente.

PRophecíA.- Peccado y Malicia son. ¡A muy buen tiempo han venido!223

Peccado.- Hermano mío Malicia, entiende que ya es llegado.

PROPHECÍA.- Ya es llegado...

PECcAdo.- El eco resuena aquí.

MALICIA.- Así es.

Peccado.- Pues ten cuenta en su sonido y advierte que tiene dicho: «Ya es llegado».

MALICIA.- Atentíssimo estaré.

Peccado.- Digo que a mí me paresce que el tiempo es llegado ya en que debría cessar este continuo servicio que al hombre mortal hacemos y que se debe buscar el remedio.

PROPHECÍA.- ... el remedio.

MALICIA.- «El remedio» dijo el eco.

PECCADO.- De modo que tiene dicho: «Ya es llegado el remedio». El remedio. Buen pronóstico paresce.

MALICIA.- Antes malo, di adelante.

PECCADo.- Assí que medio no sé para dejarle de servirle, si no es darle la muerte, que es cosa bien nescessaria para el Hombre.

PROPHECÍA.- ... para el Hombre.

PECCADO.- «Para el Hombre». Junta las partes, Malicia.

MALICIA.- «Ya es llegado el remedio para el Hombre».

PECCADO.- ¡Oh qué mala conclusión!

viento, debido a la terrible situación en que se encuentra acosado por la carne y el mundo, atizados por el pecado. En la segunda, aunque se halla en tan deplorable y terrible estado, solicita la ayuda divina con la esperanza de que le prestará la ayuda necesaria para salir de dicho estado: «que puede a tal tormenta dar bonanza».

221. Estos dos versos dan respuesta favorable a la incertidumbre del Hombre en su caminar, debido a la inenarrable situación en que se halla, manifestada en la octava anterior. Profecía y Gracia le auguran buen viaje, buena acogida (pasaje: «acogida que se hace a uno o trato que se le da» [Martín Alonso]), tiempo sereno en el mar (bonanza, recordemos la metáfora de la octava anterior) en su travesía, porque el remedio para él ha llegado.

222. noche obscura: sintagma con claras resonancias místicas.

223. Es posible que Profecía y Gracia se escondieran cuando entran Pecado y Malicia, al menos en su diálogo estos las ignoran, o quizá que los personajes formaran dos grupos independientes sobre la escena, separados por una cierta distancia. Se trata de dos escenas paralelas y simultáneas. 
GRACIA.- No es sino buena, traidor ${ }^{224}$.

PECcAdo.- ¿Quién sois vos, decid, señora, que con tanto atrevimiento me osastes llamar traidor?

GRAcIA.- La Ley de Gracia me llamo y soy del cielo venida para libertar al Hombre del captiverio infernal en que tú, traidor, lo tienes.

PECCADo.- ¿Y podreislo vos sacar de mis ${ }^{225}$ manos?

GRACIA.- Sí podré, por quien me envía y con quien vine, que es Dios.

Peccado.- Pues si es Dios, Él bien querrá que se le pague ${ }^{226}$ la ofensa que contra Él hizo el Hombre.

GRACIA.- Sí, que de pagarse ha.

PECCADO.- ¿Y227 quién la podrá pagar?

GrACIA.- El mesmo que fue offendido.

Peccado.- Decidme cómo o con qué.

Gracia.- Con su muerte.

PECCADO.- ¿Cómo puede Dios morir?

LEY.- Esa es la grande grandeza de su amor y el admirable thesoro de su inmensa charidad, que lo supo, quiso y pudo por tal concierto ordenar, que, vistiéndose de carne sin peccado, como hombre pueda morir y a Dios como Dios pagar.

MALICIA.- Peligro corres, Peccado.

PROPHECÍA.- Y tú lo corres, Malicia.

MALICIA.- Sin decirla me cognosces ${ }^{228}$. Bien adivinaba yo que el prenóstico ${ }^{229}$ del eco era malo.

GRACIA.- ¡Ora, sus, tirad ${ }^{230}$ de aquí!, que no es justo que veáis el divino advenimiento de mi Dios, pero su muerte veréis y será de tanto prescio su valor que al Hombre dará la vida, y de muerte y de pecado saldrá con grande triumpho vencedor.

MALICIA.- ¡Pon los pies en polvorosa ${ }^{231}$, Peccado!

PeCcado.- ¡Anda tú, que ya yo voy!

PROPHECÍA.- ¿Qué haces, Hombre mortal?232

224. En este momento se relacionarían ambos grupos de personajes.

225. mis: término escrito sobre un las tachado en el ms. (fol. 162r).

226. pague: page en el ms. (fol. 162r).

227. Y: ni en el ms. (fol. 162r), que el MS. B2603 lee bien (fol. 35r)

228. Sin decirla me cognosces: es decir, Malicia le dice a Profecía que, sin identificarse ante ella, esta lo conoce, pues lo llama por su nombre.

229. prenóstico: 'pronóstico'

230. tirad, tirar: «irse» (Marín Alonso).

231. Pon los pies en polvorosa: 'frase coloquial para referirse a marcharse precipitadamente de algún lugar huyendo, para intentar salvar una situación difícil que no se sabe o no se puede afrontar'.

232. En el ms., debajo de esta línea aparece la adscripción del parlamento Profeçia, sin que se le adscriba ninguno (fol. 163v). En el MS. B2603 no aparece (fol. 35v). 
HOMBRE.- Mi señora, estó esperando lo que de parte de Dios me prometistes.

PropheCíA.- Pues dame albricias, amigo, que ante ti tienes presente la divina Ley de Gracia.

HOMBRE.- ¡Oh, soberana princesa!, mi bien, dejadme tocar el cabo de vuestra ropa, que las manos no meresce quien las ha desmerescido.

GRACIA

Levanta, Hombre, y entiende lo que digo.

Sabrás que el que ab eterno fue engendrado

del Padre que es principio sin principio,

vestido nasce hoy de humana carne para matar en ella tu peccado.

Y como de raíz nasce la vara

y por vara la flor toma camino,

así de humana carne procediendo

por reyes, patriarcas y profetas 233

hoy nasce aquesta flor de olor divino.

HOMBRE.- ¿Por mí, tan grand traidor, nasce Dios hombre?

GRACIA

En brazos lo verás de una doncella, en quien al Padre plugo que encarnase, y el Niño da suspiros desseando llegase ya la hora que su sangre por darte a ti la vida derramasse.

HOMBRE ¡Oh, charidad, inmensa e inefable! ¡Oh brasas del amor del sacro pecho, en quien divino fuego tanto pudo que en llamas del amor de su enemigo tan grande sacrificio queda hecho!

PROPHECÍA

Levanta el corazón hacia los cielos y el pecho esté prostado 234 por la tierra, que agora podrán ver tus proprios ojos quien hecho por ti paz ante su Padre no pudo no cessar su cruda guerra.

Ostende nobis, Domine, misericordiam tuam et salutare tuum da nobis ${ }^{235}$

233. Se trata de la genealogía del Hijo de Dios humanado.

234. prostado: 'postrado'

235. «Muéstranos, Señor, tu misericordia, y danos tu salvación»: Salmo 84, 8, cantado en la liturgia del primer domingo de Adviento. 
Aquí se descubre el sanctíssimo nascimiento en la vara de Jessé236, Ilena de reyes, patriarchas y profetas y en lo alto la Virgen Sanctíssima María con el Niño Jessú Salvador Nuestro en los brazos, todos vivos, y entre tanto que está descubierto canta el Hombre con instrumentos este terceto.

Tu siervo lleva en paz, mi Dios, agora, pues han visto mis ojos en la carne el bien y la salud que el cielo adora.

Laus Deo et Sub Correctione Sanctae Ecclesiae Catholicae Romanae.

\section{Diálogo de dos pastores, el uno llamado Silvano y el otro Alegría}

ENCABEZAMIENTO: Diálogo de dos pastores, el uno llamado Silvano y el otro Alegría (fols. 173r-177v).

FIGURAS: Silencio (Silvano), pastor, y Alegría, pastor.

FORMA EXPRESIVA, EXTENSIÓN Y MÉTRICA: Verso y prosa. Comienza con empleo del verso: un villancico cantado (8A8B8B), seguido por una quintilla (8A8B8B8A8A), cinco estrofas de 6 versos, siendo el primero quebrado (4A8A8B8B8A8B), un pareado (10A8A), otra estrofa de 6 versos con el primero quebrado (4A8A8B8B8A8B) y un pareado (4A8A). A continuación, se pasa a la prosa, que está fragmentada por dos villancicos cantados, cerrando el auto uno tercero, siempre con el mismo esquema (8A8B8B). En conjunto, un total de 57 versos y 135 líneas en prosa aproximadamente.

ARGUMENTO: El pastor Silencio (Silvano en el título y en las dos primeras adscripciones del parlamento), en contra de su propia naturaleza, rompe a cantar y hablar para publicar las excelencias de la venida de Dios al mundo en ese día. Su hermano Alegría, extrañado, le pregunta la causa por la que ha mudado su condición, argumentándole Silencio que es para proclamar la venida del «Deseado». Alegría, regocijado, le pide que le indique cuándo y dónde ha nacido este divino Señor. Si-

236. vara de Jessé: el motivo de la vara de Jessé, representación del árbol genealógico de Cristo, en el que se descubre el nacimiento, es de origen centroeuropeo y con un período de desarrollo en su representación iconográfica comprendido entre los siglos XII y XVI (aunque hubo representaciones anteriores y posteriores a estas fechas) y, desde luego, no era ajeno a los sevillanos coetáneos de Galeas. Sin ir más lejos, en tres ocasiones aparece en el ornato interior de la catedral hispalense, como indica María Jesús Sanz (1989, pp. 121 y 124-127). La representación más visible es la que se encuentra en el friso del remate de la reja del Coro, situada frente a la capilla mayor y realizada entre 1518 y 1523, en la que el árbol se desarrolla formando una amplia crestería con la disposición tradicional (Sanz, 1989, pp. 124-125). Con una distribución ornamental muy semejante a esta, pero de fecha posterior (1564), otro árbol de Jessé decora la parte superior de la reja de la capilla llamada del obispo de Scalas, en la nave izquierda del templo (Sanz, 1989, pp. 125-126). Y, por último, aunque de identificación más problemática, un tercer árbol de Jessé, probablemente anterior a 1510, figura «en un relieve arquitectónico -en palabras de María Jesús Sanz- que se halla situado en el lado izquierdo del crucero rodeando la vidriera que corona el testero de este brazo» (1989, pp. 126-127, la cita en p. 126). Fue un tema frecuente en la iconografía cristiana de la época. 
lencio le explica que hoy es el día de su natividad y le detalla cómo y dónde ha sido. Alegría expresa su deseo de ir a ver al recién nacido y Silencio lo lleva, entonando una canción, cuyo comienzo este solicita a Alegría.

GÉNERO: Coloquio alegórico sobre el nacimiento de Cristo, con numerosas referencias bíblicas.

TEATRALIDAD: Como indica su encabezamiento es un diálogo entre dos pastores alegóricos sin rasgos de rusticidad, desprovisto de tensión dramática y con una sola acotación explicita - «Y luego proseguía el mismo Silvano representando lo que se sigue», que, unida a las implícitas, muestra al autor como dueño de la puesta en escena.

FINALIDAD: Pieza de tema y personajes alegóricos, de carácter doctrinal, para celebrar el nacimiento de Cristo el día de su natividad.

He aquí el texto:

Diálogo de dos pastores, el uno llamado Silvano ${ }^{237}$ y el otro Alegría

SILVANO

De las piedras, si queréis,

podéis vos, mi Dios, sacar

mill lenguas para os loar.

Y luego proseguía el mismo Silvano representando lo que se sigue:

SILVANO

Di, cielo, ¿quién te enseñó

hacer de la noche día,

ver trocado en alegría

lo que el peccado causó?

Dime, ¿quién lo meresció?

$$
Y \text { a ti, tierra, }
$$

¿quién es el que te destierra

las lágrimas de los ojos

y, como ricos despojos

ganados en buena guerra,

quiere tomar tus enojos?

(¿Qué miráis?

¡Ah, hombres!, ¿qué deseáis?

¿Qué pedís o qué queréis?

Descanso ya lo tenéis,

que este día lo alcanzáis

tal cual menester lo habéis.

¡Qué dulzura,

qué gozo, qué hermosura

que a ti, siervo y peccador,

te dé prendas ${ }^{238}$ tu Señor

237. Silvano: este nombre de pastor se muta por el de Silencio tras su tercera adscripción del parlamento, nombre por el que lo denomina el otro interlocutor y adecuado a su propia naturaleza. 238. v. 24 prendas: 'dones, dádivas'. 
y helo dejado de hacer más por la importunidad del tiempo que por cumplir con la auctoridad de mi oficio.

ALEGRía.- Por cierto que rescibo todo contentamiento de ver cuán avisadamente has respondido y no me espanto de que tan bien respondas, porque quien tanto ha callado justo es que hable con prudencia, pero admírame mucho de ver cómo excedes del orden de tu' 46 naturaleza.

SILENCIO.- ¿Deso te admiras, Alegría? Bien paresce cuánto te ocupas más en los placeres y regocijos humanos que en los gozos espirituales y divinos, pues pones tanta fuerza en las reglas naturales ${ }^{247}$, olvidándote de las sobrenaturales que a cada paso se hallan en los divinos hechos.

ALEGRía.- Silencio, por vida tuya, me traigas a la memoria algunas de aquestas cosas.

SILENCIO.- Soy contento. Dime, Alegría, ¿no te acuerdas del agua de la piedra de Oreb cuando Moisén la tocó?248; ¿del parar del sol en tiempo de Josué?249; ¿del fuego del cielo en el sacrificio de Helías contra los profetas de Baal? ${ }^{250}$ No te espantaras tú de ver que yo hablase, si te acordaras del asna de Balam y de cuán a propósito se volvió contra su señor, reprehendiéndole cuán sin culpa castigaba a quien el ángel del Señor para que no caminase le impedía y amenazaba ${ }^{251}$. A

246. tu: en el ms. su, que he corregido (fol. 174v).

247. reglas naturales: 'las que posee el hombre por su propia naturaleza'.

248. Silencio alude al episodio bíblico narrado en el Éxodo (17, 1-7), cuando Moisés, ante las protestas de los israelitas que se dirigen desde Egipto hacia la Tierra Prometida, a causa de la falta de agua para calmar su sed, hace brotar milagrosamente por mandato divino agua de la roca de Horeb, tras golpearla con su cayado.

249. Referencia al episodio bíblico narrado en Josué (10, 1-15), cuando en su lucha contra los amorreos, Yahveh dijo ante los ojos de Israel: «Deténte, sol, en Gabaón, y tú, luna, en el valle de Ayyalón. Y el sol se detuvo y la luna se paró hasta que el pueblo se vengó de sus enemigos» (versículos 12-13).

250. Referencia al episodio bíblico narrado en 7 Reyes, 18, 20-40, en el que el profeta Elías para demostrar ante el pueblo de Israel que él era profeta de Jehová, el Dios verdadero, frente a los profetas de Baal y los que seguían adorando dioses falsos, mandó sacrificar dos novillos, uno en un altar hecho por los profetas de Baal y otro en un altar hecho por él, ambos sin fuego, debiendo invocar cada uno el nombre de sus respectivos dioses para que ardiera. Mientras que la invocación de los primeros durante todo el día hasta la hora del sacrificio no tuvo resultado positivo, cuando Elías invocó a Jehová cayó su fuego y «devoró el holocausto y la leña, y lamió el agua de la zanja» con la que Elías había cercado su altar. Y, viéndolo todo el pueblo, «cayeron sobre su rostro y dijeron: "¡Yahveh es Dios, Yahveh es Dios!"» (las citas en versículos 38-39).

251. Referencia al episodio bíblico narrado en Números, 22, 22-36, cuando habiendo acampado los israelitas en su huida de Egipto en las estepas de Moab al otro lado del Jordán, enfrente de Jericó, y temiéndolos Balac, rey de Moab, envía a Balaán una serie de hombres principales para que consigan que los acompañe a Moab para que maldiga a los israelitas. Tras la duda, ante su negativa a ir Dios le ordena que vaya con ellos con la promesa de cumplir lo que Él le dijera. Balaán lo obedece y parte sobre su burra, acompañado por dos criados y con los jefes de Balac. Un Ángel con una espada desnuda en la mano impide tres veces a la burra seguir su camino. Balaán, ante su desobediencia, la golpea las tres veces sin conseguirlo. La burra le reprocha su actitud, pues siempre le ha sido fiel. Entonces Balaán ve al Ángel de Yahvé con la espada desnuda en la mano, el cual le dice que, si la burra no se hubiera desviado, lo habría matado y dejado a la burra con vida. Balaán se postra ante él y tras las explicaciones del Ángel reconoce que ha pecado, al no saber que era el Ángel quien se interponía en su camino. Dispuesto a volverse, el Ángel le responde que continúe y que solo diga lo que él le diga. 
millares te pudiera traer los ejemplos, si el tiempo nos diera lugar, pero yo sé que para contigo bastan los que he traído.

AlegRíA.- Silencio, iy qué placer es oírte!, espantable 252 regocijo causa en mi alma la dulce lumbre de tus palabras. Son tales los ejemplos que has traído que ni tú tienes nescessidad de traerme otros ni yo ternía razón de pedírtelos, pero quiero que me digas la causa de tu hablar, que tan sobrenatural es a ti como al asna de Balam que referiste.

SILENCIO.- ¡Oh, Alegría, y, si supieses qué me pides, con cuánta mayor instancia y cuánto más de veras lo pedirías!, mas al fin este estudio ${ }^{253}$ no se te puede negar. Comienza a regocijarte y canta nuevos cantares, da voces a Jerusalem y anuncia a las hijas de Sión 254 , clama por los desiertos, por montes, y por silvas 255 y collados hasta los fines extremos de la tierra, evangeliza al mundo, que ya es venido del cielo su «Desseado», la esperanza de las gentes, el cumplimiento de las promesas divinas y el único prescio con que Dios quiere ser pagado y sin el cual ninguno le puede pagar $^{256}$.

\section{El cielo se regocija \\ y la tierra se alboroza \\ y a mí la risa retoza 257 .}

[ALEGRÍA.-] ¡Sancto Dios, y qué placer, qué nueva, qué regocijo, qué descanso y qué contento! ¡Oh, Silencio ${ }^{258}$, que bienaventurado ha sido tu no hablar, pues para tal día estaba guardado! Bien se podría decir que se ha cumplido en ti una de las señales que dice Esaías que ha de haber en la venida de este príncipe de paz. Entonces dice soltarse ha la lengua de los mudos, saltarán los zopos ${ }^{259}$ como ga- $^{-}$ mos, abrirse han los ojos de los ciegos y ternán los sordos oídos, habitará el lobo con el cordero y andarán el pardo ${ }^{260}$ con el cabrito, leones con ovejas, y los ossos

252. espantable: «excelente, admirable, maravilloso, sumamente portentoso y grande, y digno de asombro» (Aut.).

253. estudio: «aplicación a saber y entender» (Aut.); es decir, 'el conocimiento de la causa de que Silencio hable, en contra de su propia naturaleza'.

254. Sión era una fortaleza situada en la colina oriental de Jerusalén, «conquistada por David, y llamada desde entonces "ciudad de David" (2Sam 5,7, 1Re 8,1). Después que David trasladó allí el arca de la alianza, a Sión se le llamaba principalmente lugar de la morada de Jahvéh. Cuando Salomón edificó el templo al norte de la cuidad de David y trasladó allí el arca, se llamó también Sión al monte del templo, aunque el nombre de Sión se empleaba igualmente para designar a toda la ciudad o a sus habitantes ("Ios hijos o las hijas de Sión") e incluso a veces a todo el pueblo de Israel (Is 40, 9, 46, 13, etc.). La ciudad, juntamente con sus habitantes, fue también llamada "hija de Sión"» (Diccionario de la Biblia, s. v. Sión). 255. silvas: 'selvas'

256. Este canto de júbilo por la venida del Mesías es una libre adaptación de Zacarías, 9, 9, pasaje que se repite con variantes en otros lugares del Antiguo Testamento.

257. retoza: en el ms. retoca (fol. 175v), que he corregido como piden la rima y el sentido. Retozar la risa: «Frase que significa querer reír, o estar movido a risa, procurando reprimirla» (Aut.).

258. Silencio: este nombre va precedido en el ms. por el término Silvano, subrayado y entre paréntesis (fol. 176r)

259. zopos, zopo: «el lisiado de pies, o manos» (Aut.); es decir, cojos, como leemos en el texto de Isaías. 260. pardo: «animal fiero muy ordinario de África, tiene la piel olorosa y manchada con unos ojos» (Cov.) / «animal lo mismo que tigre» (Aut.). 
con becerros, un niño tierno los podrá apascentar ${ }^{261}$. Mira, Silencio, pues estabas mudo y tienes ya lengua, y te hallaba yo sordo y agora me oyes, justo será me des mayor relación y me avises cuándo y dónde nasció este divino Señor.

SILENCIO.- Entiende, Alegría, que hoy es el día de su natividad. Hoy cumple la profecía de las hebdomadas ${ }^{262}$ de Daniel 263 y la del patriarca Jacob, pues cesaron ya en Israel los reyes de su casta ${ }^{264}$. No nasció en palacios ni en casas reales, sino en Belem en un pobre pesebre entre dos animales para desbaratar los faustos y pompas del mundo y para dar a entender que su reino es espiritual y assí no va guiado por reglas ni paresceres humanos. Nasció de madre virgen sanctíssima, la más perfecta y la más acabada de cuantas Dios ha criado, y es cosa digna de su gloria que, siendo el Hijo tal Hijo, tuviese madre tal madre.

$$
\begin{aligned}
& \text { ¿Oh, qué día y qué lugar, } \\
& \text { qué virgen madre y qué hijo, } \\
& \text { qué gozo y qué regocijo! }
\end{aligned}
$$

[ALEgría.-] ¡Oh qué divina armonía, qué orden y qué concierto, qué graciosa proporción, cómo se responde todo! Madre y virgen, ¿a quién pudo ella parir sino a Dios? Dios y hombre, ¿qué madre pudo tener sino tal cual la has pintado? Sabes, Silencio, ¿qué estaba pensando? Que necio quedara y asmado ${ }^{265}$ de verte hablar, si aqueste divino ${ }^{266}$ no supiera, más agora tu hablar téngolo en poco, porque, cuando tú callaras, de piedras hiciera Dios nuncios ${ }^{267}$ de aquesta alegría.

SILENCIO.- Así espero. Entiende, Alegría, que por voces angélicas venidas del cielo se ha annuntido 268 hoy a la tierra la gloria del Señor, la grandeza de su misericordia, su buena voluntad para los hombres y el cumplimiento de aquella paz prometida. Para que sepa el mundo que Dios es ${ }^{269} \tan$ fiel y tan amigo de cumplir su palabra que faltará el cielo y la tierra y Él no faltará270, y de aquí quede el justo enseñado a esperar en el remedio de sus males, la paga de sus trabajos, la muestra de su bondad y la declaración de su innocencia; y para que el malo quede asimismo avisado a temer sus juicios, a atemorizarse de sus amenazas y a huir sus castigos.

261. Como indica el autor, la fuente de estas señales que acompañarán la venida del Mesías es Isaías, $35,5-6$, y $65,25$.

262. hebdomadas, hebdomada: «el número de siete días, u de siete años, que más comúnmente se llama semana» (Aut.).

263. Referencia a las setenta semanas fijadas por el ángel Gabriel al profeta Daniel $(9,24)$ para la venida del Mesías.

264. Referencia bíblica a Jacob, cuando antes de morir bendice a sus doce hijos, cabezas de las doce tribus de Israel, augurándoles lo que les ocurrirá al cabo de los días (Génesis, 49); y, en concreto, a Judá $(49,10-12)$ en un pasaje de evidente sentido mesiánico.

265. asmado: «asombrado, atónito» (Martín Alonso).

266. aqueste divino: el ms. omite el sustantivo soporte de ambos términos, el cual por el contexto podría ser aviso, en el sentido de 'noticia, nueva'.

267. nuncios, nuncio: «el que lleva aviso, noticia u encargo de un sujeto a otro, enviado a él a este efecto» (Aut.).

268. annuntido: 'anunciado'

269. es: verbo entre el sujeto - Dios - y su correspondiente predicado nominal - tan fiel y... - omitido en el ms., que he restituido.

270. Palabras del versículo bíblico de Mateo, 24, 35, con variantes, pero con el mismo sentido. 
ALEGRíA.- Sí, hermano mío. Así te consuele Dios, me lleves a ver aqueste recién nascido, porque tengo para mí que en ese pobre pesebre y esa grande bajeza se le ha de ar[r]odillar cuanto Dios tiene criado, y querría 271 en este dichoso día regocijarlos a todos con nuevas formas y modos de alegría.

SILENCIO.- Muy bien dices, Alegría. Yo te llevaré conmigo, pero mira que ni su bajeza te espante ni su pobreza te desmaye, porque son dos cosas en que tú pocas veces te sueles hallar.

AlEgRíA.- Engañado vives, Silencio, si piensas que bajeza y pobreza me espantan a mí, porque no solamente me hallo con ellas, pero también me suelo hallar en lágrimas y sospiros en los tormentos y muertes de los justos. Bien sentía el profeta que me tenía consigo, cuando decía: «Según la multitud de los dolores en mi corazón, alegraron, Señor, mi alma tus consolaciones» ${ }^{272}$. ¿No sabes tú que uno de los fructos del espíritu es alegría? ¿Pues donde Él residiere cómo puedo yo faltar?

SILENCIO.- Por cierto lo has dicho muy bien. Vente ${ }^{273}$ conmigo, Alegría, y verás lo que deseas.

Alegría.- Vamos cantando, Silencio.

SILENCIO.- Comienza tú, Alegría, un cantar regocijado.

¡A quien tal bien nos ha dado, cantemos en este día mill cantares de alegría!

Laus Deo.

\section{Colloquio pastoril para el sanctíssimo nascimiento}

ENCABEZAMIENTO: Colloquio pastoril para el sanctísimo nascimiento (fol. 195r).

FIGURAS: Pastor innominado; Antón, pastor; Pedro, pastor, y posiblemente otros pastores, cuyo número no se indica.

FORMA EXPRESIVA, EXTENSIÓN Y MÉTRICA: 30 versos de arte menor, agrupados en dos estrofas de 10 versos recitados de rima consonante y un villancico final de 10 versos cantados también con rima consonante, con el siguiente esquema:

Primera estrofa: 8A8B8A8B8A 8A8C8D6D6C

Segunda estrofa: 8A8B8A8B8A 8A8C8A6A6C

Más un Villancico final: 8A8B8B 8C8D8D8C 8C8B8B.

271. querría: tras este término figura un que tachado por una raya en el ms. (fol. 177r).

272. Salmo 93, 19, atribuido al rey David: «Secundum multitudinem dolorem meorum in corde meo, consolationes tuae laetificaverunt animam meam».

273. Vente: en el ms. vete (fol. 177v), que he corregido, al considerarlo por el sentido imperativo del verbo venir. Recordemos que, en un parlamento anterior, Silencio le dice a Alegría: «Yo te llevaré conmigo» (ms. fol. 177r) 
ARGUMENTO: Un pastor innominado invita a otros pastores, uno llamado Antón y otro Pedro, a entonar con sus instrumentos musicales -flautas - una canción y a ensayar una danza para bailarla ante el «Divino humanado», es decir, Jesús recién nacido, en su loor. Un villancico cierra la breve composición.

GÉNERO: Francisco Galeas califica la breve y ágil pieza como «coloquio pastoril». Se trata de un diálogo implícito, porque, aunque los demás pastores están presentes, no toman la palabra, limitándose a «tañer y cantar» el villancico final.

TEATRALIDAD: Los pastores presentes, a través de sus gestos, movimientos y el son de sus instrumentos que acompañarían con sus voces, dotarían de cierta teatralidad el corto desarrollo de la composición.

FINALIDAD: Pieza en loor al nacimiento del Verbo encarnado por amor al hombre, cuyo villancico final presagia ya su futura pasión y muerte.

He aquí el texto:

¡Toquen las flautas, Antón,

un tono regocijado!

Cantaremos a su son

al Divino desposado 274

una graciosa canción.

¡Suso!, con la bendición

y con la buena ventura 275 ,

que canción será de amor

que tiene el Señor

a la crïatura ${ }^{276}$

Pedro, que sabe guïar277,

ordene luego una danza,

irémosla a presentar

a mi única esperanza 278

que se vino desposar.

¡Suso!, tañer y cantar 279

un villancico escogido,

en que se pueda tractar

que Dios por amar

en carne ha nascido.

274. v. 4 Divino desposado: 'Jesús, Dios y hombre, por la unión hipostática de ambas naturalezas, divina y humana, en una sola persona'. Es decir, cuando Cristo se encarnó, continuó siendo Dios y agregó como hombre la naturaleza humana, sin dejar de ser Dios.

275. v. 7 buena ventura: «El caso favorable, o suerte dichosa y feliz, que acontece a alguno, especialmente cuando no se espera» (Aut., s. v. ventura).

276. v. 10 la crïatura: 'el hombre'.

277. v. 11 guïar: «guiar la danza: frase metafórica, que vale ser el principal por quien se gobierna alguna cosa» (Aut.).

278. v. 14: mi única esperanza: 'Jesús'.

279. v. 16 tañer y cantar: infinitivos con valor de imperativos. 
Laus Deo.

La lectura de los textos permite poner de manifiesto que Galeas parece encontrarse experimentando sobre la forma de dar cuerpo a estos textos religiosos de asunto navideño, ensayando con el verso (I y V), con la prosa (II), y con la utilización de ambos en una misma pieza (III y IV), recurriendo en ellas al empleo de breves canciones cantadas («villancicos»)281. Todas las piezas se apoyan en el asunto que se celebra y sus benéficos efectos, con el desenlace de la ida a adorar al recién nacido. Para ello, se sirve, excepto en una (V), del procedimiento retórico de la alegoría, utilizando en tres (I, II y IV) el motivo recurrente del enfrentamiento de personajes opuestos por naturaleza, de los cuales uno de ellos cambia de identidad por el nacimiento de Cristo (I. Fortaleza / Flaqueza; II. Riqueza, Solicitud, Curiosidad / Pobreza, Sosiego, Simplicidad; y IV. Silencio / Alegría). De este esquema, se separa en cierta medida la pieza III, heredada de una tradición recibida como hemos señalado; sin embargo, aunque con una panoplia de personajes más variada, también se podrían reducir a la dilogía «fuerzas del mal» (Peccado y Malicia) / «fuerzas del bien» (Ignorancia, Prophecía, Ley [divina], Gracia [Ley de]), con el Hombre en medio de ellas, al lado de unas o de otras. Estos posicionamientos alegóricos dialécticos, le dan pie al autor a la creación de un diálogo ágil y flexible que le posibilita la catequización. A base de un estilo sencillo y cortas réplicas, junto a la presencia en algunas piezas de personajes cotidianos para el espectador (dos truhanes [II], dos charlatanes [III], pastores [II y V]) o su caracterización como tales de personajes alegóricos [ I y IV], el autor consigue el acercamiento de las obras al público y el éxito de su propósito doctrinal. Es verdad que la $\vee$ se separa de este esquema, pudiendo incluso discutirse su naturaleza propiamente dramática, hasta el punto de que, como se ha indicado, Regueiro y Reichenberger no la incluyen en su catalogación. No obstante, aquí se ha estimado conveniente considerarla, porque, a mi juicio, posee ciertas características dramáticas: presencia de varios interlocutores caracterizados como pastores, que portan instrumentos musicales propios de su condición y

280. v. 28 llevado: en el ms. llegado (fol. 195r), que he corregido.

281. Del resto de su producción dramática, solo queda inédita una pieza: Introito para representación a la venida del III. mo Arzobispo de Seuj. ${ }^{a}$ [...] (fols. 94r-95r), en verso (para un acercamiento a ella, ver Reyes Peña, 2017, pp. 132-133). La historia de cuando Abraham echó de casa a Ismael y Agar, su madre (fols. 105r-109v), en verso, fue tratada y publicada en el citado artículo (pp. 134-136 y 149-154), como se ha indicado; y la Representación breve para el día del Sanctíssimo Sacramento [...], también en verso (fols. 20r-21r), ha visto la luz recientemente (Reyes Peña, 2020). 
se comportan como tales, y diálogo latente: uno de ellos habla dirigiéndose a los otros, transmitiéndole información y órdenes que los otros debían de ejecutar, pues finaliza con un villancico cantado y plausiblemente danzado. Es decir, aunque mínimamente, existe un conflicto por el que el Pastor innominado urge al resto de sus compañeros a celebrar el santísimo nacimiento, a realizar una acción que tiene una plasmación escénica y profundamente teatral.

Por último, tras el estudio y edición de estas cinco piezas dramáticas de Francisco Galeas, como hacía tras su presentación en 2017 con el conjunto de su producción teatral, se impone proyectarlas sobre un marco más amplio: el del corpus teatral castellano del siglo XVI y primeros años del XVII, en este caso concreto comparándolas con piezas escritas con motivo del nacimiento de Cristo. Como afirmábamos entonces, cuatro de cinco obras (exceptuada la V, que entonces no trataba), a diferencia de lo que ocurría con obras compuestas para la Navidad por Juan del Encina, Lucas Fernández, Gil Vicente, Bartolomé de Torres Naharro, Pero López Ranjel, Fernán López de Yanguas, Pedro Suárez de Robles o Diego Sánchez de Badajoz, no se insertan en la tradición del teatro de pastores, tan unido a esta festividad litúrgica, sino en la dramatización de un mundo alegórico, tanto por sus personajes como por los temas que escenifican. Entre los dramaturgos citados, ya el portugués Gil Vicente había ofrecido ejemplo de ello y, en particular, el extremeño Diego Sánchez de Badajoz, cuya Recopilación en metro se publica en Sevilla, en 1554, por el clérigo Juan de Figueroa, su sobrino. Sin embargo, en ambos autores, el vehículo expresivo es el verso, mientras que en tres de esas cuatro piezas natalicias de Galeas es predominante la prosa.

Este empleo de la prosa, así como otras características de nuestras obras, conducen a conectarlas con la línea en que se insertan las tres piezas del MS. B2603 y, más allá en el tiempo, con la tradición de la producción de Lope de Rueda o de Alonso de la Vega, autores-actores que, junto a otros como Juan Timoneda, están experimentando a mediados del siglo XVI una nueva forma de hacer teatro, en la que, a imitación de los modelos italianos, la prosa sustituye al verso. Como señala Alfredo Hermenegildo, a propósito de esta novedad en el teatro de Lope de Rueda, «el uso de la prosa permite llegar más fácilmente a crear texto en el momento mismo de la representación» y le da al teatro «una movilidad y flexibilidad que el verso, muy útil por otra parte, le niega» 282 . Además, añadiríamos nosotros, la naturalidad de la prosa frente al mayor artificio del verso proporcionaba una forma más fácil de escritura -y de recitación- para autores circunstanciales o aficionados, como pudo ser Galeas. Ni el sevillano Lope de Rueda, ni Alonso de la Vega, «vecino de Sevilla» en 1560, le serían ajenos. La producción dramática de ambos aparece publicada por Juan Timoneda, en Valencia, en la década de 1560: en 1566 ven la luz las Tres famosíssimas comedias de Alonso de la Vega y, en 1567, Las quatro comedias y dos coloquios pastoriles y El Deleytoso de Lope de Rueda, con una segunda edición de la primera de estas dos últimas obras en Sevilla, por Alonso de la Barrera, en 1576. Es verdad que, dada la fecha de nacimiento de Galeas, 1567, ese influjo no pudo ser directo, es decir, en vida de estos actores-autores, pero sí pudieron marcarle 
las huellas que dejaron; esas otras tres representaciones del nacimiento aludidas (MS. B2603); las representaciones de las compañías de commedia dell'arte que visitan Sevilla desde el último tercio del siglo (la célebre de Ganassa llega por primera vez en 1575), así como la actividad dramática que hubo en los colegios de la Compañía de Jesús, las universidades y las academias en la capital hispalense durante la segunda mitad del Quinientos.

La escritura teatral en prosa de esos años del siglo XVI, que podríamos situar en un arco comprendido entre las décadas de 1540 y 1570 (como se observa también en el Auto de los desposorios de Moysén y el Auto de Naval y de Abigaíl del Códice de Autos Viejos, que se han atribuido a Lope de Rueda) ${ }^{283}$ y algo más adelante, será, con algunas excepciones (como las citadas de Galeas), superada a medida que avanza el siglo por la primacía del verso. Este acabará imponiéndose, a pesar de la ardiente defensa que hacen de aquella los comediantes italianos que actuaron en España en el último tercio del siglo XV ${ }^{284}$. Uso este del verso al que no se sustraen por completo los autores de algunas de las obras en prosa citadas, como tampoco el propio Galeas.

La presencia del metro italiano en el teatro anterior a Lope de Vega se halla documentada por Morley, con un uso tímido del soneto y la octava en una o dos piezas representadas en el período de 1530 a 1575, relegando el uso del terceto al período comprendido entre 1575 y $1587^{285}$. Es verdad que el citado investigador establece su cronología a partir de una serie de obras entre las que no aparecen las nuestras, pero el panorama métrico que traza puede servir de punto de referencia para la ubicación de las que estudiamos. Con estas reservas, la mezcla de prosa y versos endecasílabos en estas piezas permite mantener esa datación de finales del segundo tercio del Quinientos o principios del Seiscientos. ¿Sería esa utilización del verso por Galeas - nos preguntamos - un deseo de romper la exclusividad de la prosa? Pero conviene tener en cuenta que el uso del verso había continuado vigente en el teatro religioso -basta considerar las piezas del Códice de Autos Viejos-, si bien con un predominio de los metros españoles. ¿O respondería más bien a un deseo de dignificar con el prestigio de los metros italianos la forma expresiva de algunos personajes o de determinados pasajes?286. Sin embargo, su empleo en el Introito de la III, ejecutado por «quien suele hacer un Simple», aunque en tono serio, resta fuerza a esta suposición, al menos que, en el caso de los dos Introitos, su empleo viniera determinado por la categoría de la persona a la que van dirigidos.

283. Reyes Peña, 1988, vol. I, pp. 155-164.

284. Sobre el uso y defensa de la prosa por la generación de autores-actores y por los comediantes italianos, su abandono posterior y el triunfo definitivo del verso, ver Ojeda Calvo, 1995, pp. 129-130, Froldi, 1996, pp. 278-289, y Granja, 1998, pp. 257-262.

285. Morley, 1925, pp. 527-529.

286. En la Representación del nacimiento de Jesucristo Salvador nuestro, aparecen en el cuerpo de la obra en un diálogo entre el Hombre y Ley divina (siete tercetos encadenados); en un parlamento en el que el Hombre se dirige a Dios (una octava); y, en el pasaje final, cuando Ley de Gracia comunica al Hombre el nacimiento de Cristo (cinco estrofas de cinco versos endecasílabos). 
Limitaciones de espacio aconsejan terminar nuestro estudio, cuyo objetivo ha sido dar a conocer estas cinco piezas natalicias navideñas, incorporándolas a la historia del teatro castellano de la época.

\section{BiBLIOGRAFÍA}

Alemán, Mateo, Guzmán de Alfarache, ed. Luis Gómez Canseco, Madrid, Real Academia Española, 2012.

Alonso, Martín, Enciclopedia del idioma. Diccionario histórico y moderno de la lengua española (Siglos XII al XX), etimológico, tecnológico, regional e hispanoa-

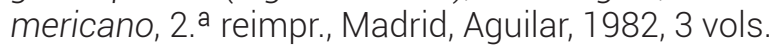

Alonso Hernández, José Luis, Léxico del marginalismo del Siglo de Oro, Salamanca, Universidad de Salamanca, 1976.

Alvar, Manuel, y Pottier, Bernard, Morfología histórica del español, Madrid, Gredos, 1993, 2. ${ }^{\text {a reimpr. }}$

Aut. = Diccionario de Autoridades, Madrid, Real Academia Española, 1726-1739, ed. facs.: Madrid, Gredos, 1984, y en línea (NTLLE).

Biblia de Jerusalén, 4. ${ }^{a}$ ed., nueva ed. totalmente revisada, Bilbao, Desclée de Brouwer, 2009 (1. ${ }^{\text {a }}$ ed. 1967).

Bisso, José, Crónica de la provincia de Sevilla, Madrid, Rubio, Grillo y Vitturi, 1869, Biblioteca de Andalucía, en línea: http://www.bibliotecavirtualdeandalucia.es/ catalogo/es/consulta/registro.cmd?id=1001694.

CORDE = Corpus Diacrónico del Español, Real Academia Española, en línea.

Cov. = Covarrubias Horozco, Sebastián de, Tesoro de la lengua castellana o española (1611), ed. integral e ilustrada de Ignacio Arellano y Rafael Zafra, Madrid / Frankfurt am Main, Iberoamericana / Vervuert, 2006.

Diccionario histórico de las calles de Sevilla, dir. Antonio Collantes de Terán Sánchez, Josefina Cruz Villalón, Rogelio Reyes Cano y Salvador Rodríguez Becerra, Sevilla, Consejería de Obras Públicas y Transportes (Excmo. Ayuntamiento de Sevilla), 1993, 3 vols.

DRAE = Diccionario de la lengua española, Madrid, Real Academia Española, en línea.

Froldi, Rinaldo, «l comici italiani in Spagna», en Covegno di Studi «Origini della Commedia Improvvisa o dell'Arte. Roma, 12-14 ottobre, 1995. Anagni, 15 ottobre 1995», ed. Maria Chiabò y Federico Doglio, Roma, Centro Studi sul Teatro Medioevale e Rinascimentale, 1996, pp. 273-289. 
García Aguilar, Idalia, «Religión y tipografía: la protesta de fe en el impreso novohispano», en Memoria del XXVI Coloquio de Investigación Bibliotecológica y sobre la Información, comp. Filiberto Felipe Martínez Arellano y Juan José Calva González, México, Universidad Nacional Autónoma de México (Centro Universitario de Investigaciones Bibliotecológicas), 2009, pp. 215-263.

Gómez, Ildefonso M., en colaboración con un cartujo del Aula Dei, Escritores cartujanos españoles, Barcelona, Abadía de Montserrat, 1970 (volumen separata de Studia Monastica, 9, 1967 y 11, 1969, con algunas correcciones de detalle, un nuevo prólogo del P. General de la Cartuja y cinco índices).

Granja, Agustín de la, «La fecha de composición de El retablo de las maravillas», Anales Cervantinos, 34, 1998, pp. 255-267.

Grimal, Pierre, Diccionario de mitología griega y romana, Barcelona, Paidós, 1981.

Hermenegildo, Alfredo, El teatro del siglo XVI, Madrid, Júcar, 1994.

Hermenegildo, Alfredo, «Figuras reales en el Códice de Autos Viejos: teatralización y dramatización de la catequesis», Castilla. Estudios de Literatura, 0, 2009, pp. 166-191.

Ibisate Lozares, Ángel, «Impresos complutenses del siglo XVI en la Biblioteca del Seminario Diocesano de Vitoria. Notas a La imprenta en Alcalá de Henares (1502-1600) de Julián Martín Abad», Scriptorium Victoriense, 44, 3-4, 1997, pp. 305-330.

Keniston, Hayward, The Syntax of Castillan Prose. The Sixteenth Century, Chicago (Illinois), The University of Chicago Press, 1937.

Llorens Cisteró, José María, Francisco Guerrero. Opera Omnia. Motetes XXIII-XLVI, Madrid, Consejo Superior de Investigaciones Científicas, 1988.

Madoz, Pascual, Diccionario geográfico-estadístico-histórico de España y sus posesiones de Ultramar, Madrid, Est. Literario-Tipográfico de P. Madoz, y L. Sagasti, 1846-1850, 16 vols.

Montoto y Vigil, Pedro, Guía general de Sevilla, Sevilla, Imp. Carlos Santigosa, s. a.

Morley, S. Griswold, «Strophes in the Spanish Drama before Lope de Vega», en Homenaje ofrecido a Menéndez Pidal, Madrid, Hernando, 1925, vol. I, pp. 505531.

NTLLE = Nuevo Tesoro Lexicográfico de la Lengua Española, Real Academia Española, en línea.

Ojeda Calvo, María del Valle, «El zibaldone de Stefanello Botarga», Criticón, 63, 1995, pp. 119-138. 
Oliveres, Juan (ed.), Colección de refranes y locuciones familiares de la lengua castellana, con su correspondencia latina, Barcelona, Librería de Juan Oliveres, Editor, 1841.

Perea Rodríguez, Óscar, «Juego de maesecoral», en Gran Enciclopedia Cervantina, vol. VII [ínsula Firme-Luterano], Madrid, Centro de Estudios Cervantinos / Castalia, 2010, pp. 6516-6518.

Protocolo / de el Monasterio de Nra. S. a / Santa María de las Cuevas. / Tomo Primero / Anales en los Tres Primeros Siglos / de su Fundacion. / [...] / Van Insertos los de la Santa Cartuxa de la Purisima Concepcion de Cazalla Fundada / y Dotada por esta de las Cuevas / [...] / Año de 1744, con colofón de 1745, por el V. P. D. José María Rincón, manuscrito, en fol., con retratos a pluma de los priores de Pedro Duque Cornejo, Madrid, Real Academia de la Historia, Sig. 9-2098.

Regueiro, José María, y Reichenberger, Arnold G., Spanish Drama of the Golden Age. A Catalogue of the Manuscript Collection at the Hispanic Society of America, New York, The Hispanic Society of America, 1984, 2 vols.

Reyes Peña, Mercedes de los, El «Códice de Autos Viejos». Un estudio de historia literaria, Sevilla, Alfar, 1988, 3 vols.

Reyes Peña, Mercedes de los, «Tres representaciones inéditas del siglo XVI sobre el nacimiento de Cristo», en «Por discreto y por amigo». Mélanges offerts à Jean Canavaggio, ed. Christophe Couderc y Benoît Pellistrandi, Madrid, Casa de Velázquez, 2005, pp. 319-343.

Reyes Peña, Mercedes de los, «La producción dramática inédita de Francisco Galeas (Hispanic Society of America, MS. HC380/611)», en Homenaje a Francisco Ruiz Ramón, coord. Luciano García Lorenzo, Hipogrifo. Revista de literatura y cultura del Siglo de Oro, 5.1, 2017, pp. 115-154.

Reyes Peña, Mercedes de los, «Pieza dramática inédita de Francisco Galeas para la festividad del Corpus», Diablotexto Digital, 8, 2020, pp. 106-121. DOI: https:// doi.org/10.7203/diablotexto.8.18304.

Ripa, Cesare, Iconología, Madrid, Ediciones Akal, 2002, 2 tomos.

Rouanet, Léo (ed.), Colección de autos, farsas y coloquios del siglo XVI, Barcelona / Madrid / Mâcon, Protat Hermanos Impresores, 1901, 4 vols. Ed. facs.: Hildesheim / New York, Georg Olms Verlag, 1979.

Sánchez Gordillo, Alonso, Svmaria relación del insigne Monasterio de Santa María de las Cuevas de Sevilla, del Orden de la Cartvxa. Ordenada por el Licenciado Alonso Sánchez Gordillo, Presuítero, natural de Seuilla, Protonotario Apostólico, Abad mayor de la Clerecía, Fiscal de la Reuerenda Cámara en todo el Arzobispado. Beneficiado propio y cura de la Iglesia de la Magdalena, Juez apostólico en muchas causas eclesiásticas. En este año de 1663, de su hedad 72, 
en Abad Alonso Sánchez Gordillo, Memorial sumario de los arzobispos de Sevilla y otras obras, ed. de José Sánchez Herrero, pról. de Juan Gil e índices de Silvia María Pérez González, Sevilla, Ayuntamiento de Sevilla, 2003, pp. 338-394.

Sanz, María Jesús, «Algunas representaciones del árbol de Jessé, durante el siglo XVI, en Sevilla y su antiguo reino», Cuadernos de Arte e Iconografía, 2.4, 1989, pp. 120-127 + 8 láms.

Stevenson, Robert, La música en las catedrales españolas del Siglo de Oro, Madrid, Alianza, 1993. 